Historic, Archive Document

Do not assume content reflects current scientific knowledge, policies, or practices. 


\section{GLE $\mathbb{E}$ SATN MARY NURSERIES}

GLEN SSAUNTIMARY, FLORIDA

1910 




Citrus trees in the Nursery

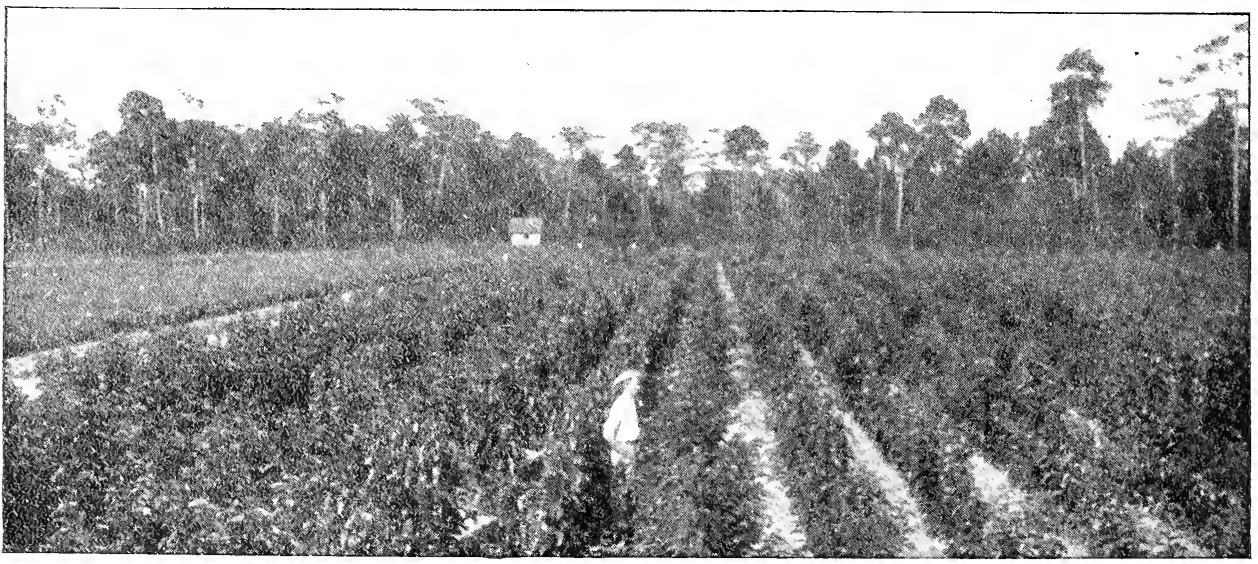

A block of Persimmon trees

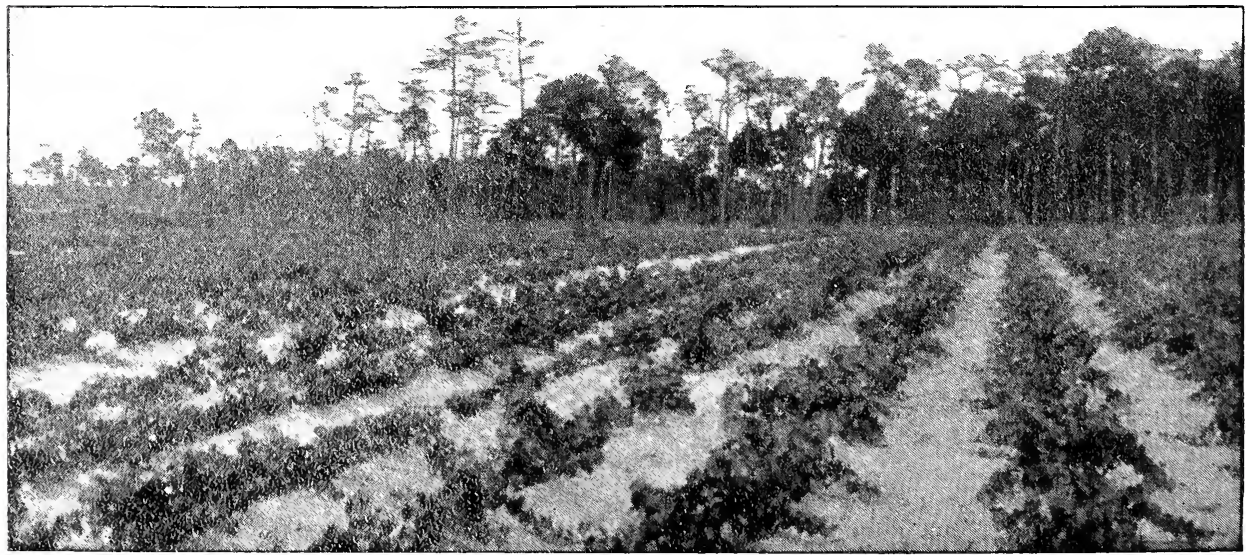

The Muscadine Grape Nursery 




VIEW AT GLEN SAINT MARY NURSERIES

Established 1882

\section{GLEN SAINT MARY NURSERIES COMPANY}

G. L. TABER, Pres. and Treas.

H. HAROLD HUME, Vice-Pres. and Sec.

W. P. JERNIGAN, Asst. Treas.

M. M. BASS, Field Manager

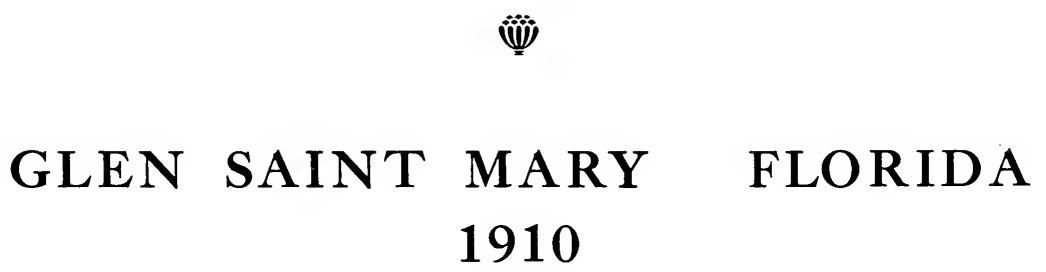




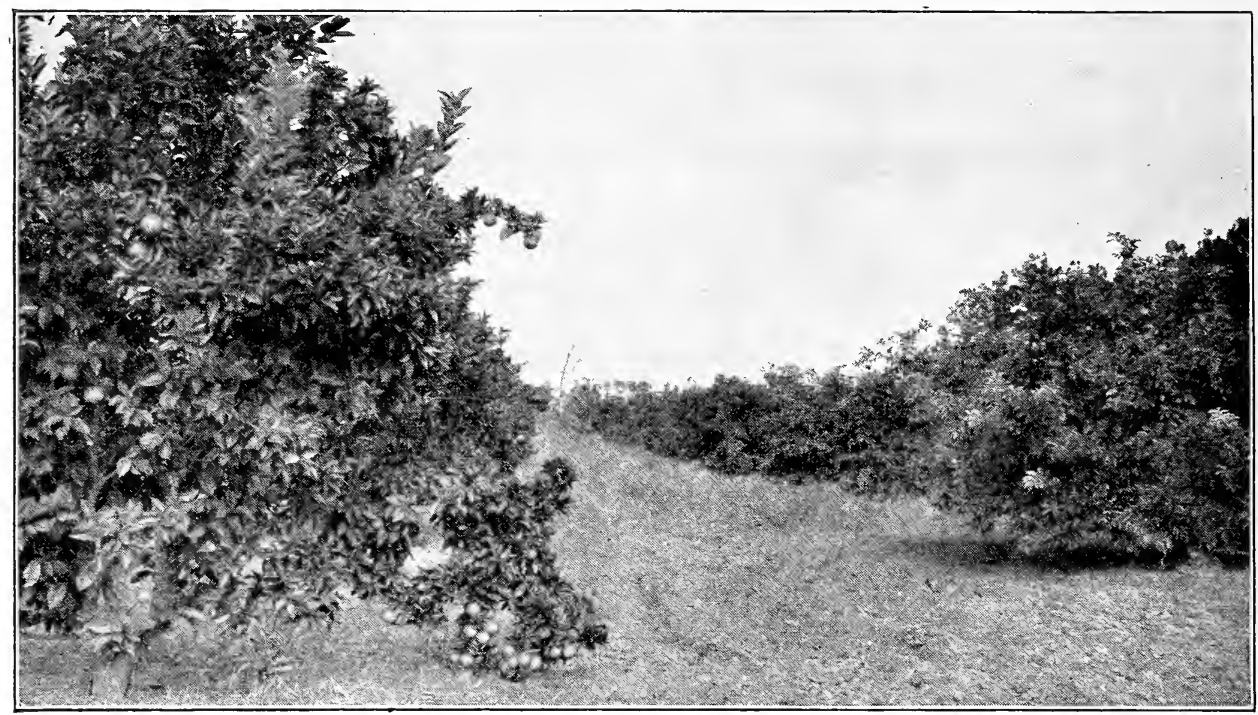

Our Citrus Test Grove

\section{Foreword}

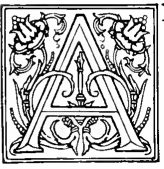

NOTHER YEAR OF SUCCESS has added its testimony to the vitality of the idea on which the Glen Saint Mary Nurseries were founded, in I883-the idea of supplying Gulf Coast planters with trees and plants especially adapted and especially propagated for their needs.

AGAIN have the matured and fruiting trees from Glen Saint Mary Nurseries, in home grounds and orchards all over the Gulf States, "made good" and proved still more completely that in horticulture, as elsewhere, pedigree and training count. It is little wonder that old customers come to us year after year, and that with only a limited amount of advertising new patrons add their demands for our stock until it taxes our resources to supply all-our "finished product" so efficiently tells the story of the quality the people want.

FOR Igro we are better equipped than ever before to render thoroughly satisfactory service to our trade. Our facilities have been still further enlarged and improved, and our stock is bettergrown and more efficiently handled with each added year's experience. The special study of Gulf Coast needs in trees and plants that has made famous the Glen Saint Mary Nurseries testing grounds is maintained, increased and perfected as we move on, every achievement spurring us to more ambitious attempts for the future.

"GULF COAST NEEDS." "Trees for the Southland," "Trees True to Name" and "Trees that Thrive" are mottos inseparably connected with the name of Taber and Glen Saint Mary Nurseries. We are as jealous of our reputation along these lines as of our personal honor or financial standing. Old friends need no assurance on the quality of trees and plants produced in Glen Saint Mary Nurseries-and those not yet acquainted with us we invite to give our stock a trial, risking entirely the future of our dealings with them upon our ability to serve to complete satisfaction.

Sincerely yours

\section{G. L. TABER, President}




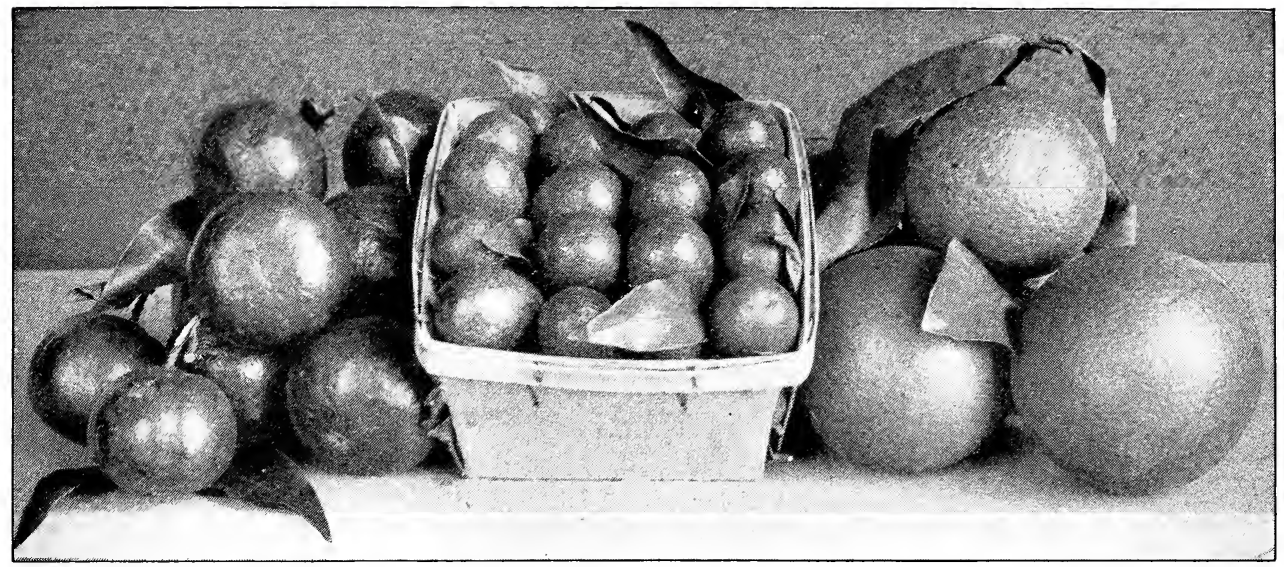

\section{Citrus Fruits}

In planting Citrus Fruits, three things are of primary importance-soil, climate and trees.

Good judgment must be exercised in the selection of a location, that the trees may be set in ideal surroundings, for no amount of expense and labor will overcome unsuitable conditions.

Having selected a good soil and a suitable location, it is essential that good trees be procured. These should be well grown with clean, smooth trunks, not stunted nor bark bound, but vigorous thrifty trees. They should be free from insects and diseases, carefully dug and carefully packed, so as to reach the planter in good condition.

In addition to all this, the trees must be "true to name," for no one can tell until they come into bearing whether they are or not, and success or failure depends on their genuineness. In growing our trees, we spare no expense in producing the best that can be grown. We produce trees to fill the conditions set forth above. Our constant aim is to secure quality, for the purchase of cheap, poorly grown, mixed trees is the most expensive investment that can be made.

Unless otherwise instructed, all Citrus trees are trimmed ready for planting before shipping.

\section{Trees on Sour Orange and Rough Lemon Stocks}

For general planting in the Citrus districts, Sour Orange stock will be found most satisfactory. It is adapted to a wide range of territory and conditions, but prefers rather heavy soil and a good supply of moisture. Its habit of developing a deep root system, its thrifty vigorous growth, its hardiness, its immunity from foot-rot, and its general adaptability to different varieties of Citrus fruits, are all strong points in its favor and well worthy of note.

Rough Lemon stock produces a very strong growth of the bud placed upon it. It is recommended for planting on dry soils and in those localities where either lack of moisture or trying soil conditions render the use of Sour stock inadvisable. It is particularly adapted to deep sandy soils. Most shy-bearing varieties are much more prolific on Rough Lemon stock. It cannot be recommended for the colder sections.

PRICES ON ORANGES.-On Sour Orange and Rough Lemon stocks :

\begin{tabular}{|c|c|c|c|c|}
\hline & Each & Per ro & 100 & I, Oco \\
\hline to 3 fee & & $\$ 3$ oo & $\$ 2500$ & $\$ 220$ oo \\
\hline 3 to 4 feet. & 40 & 350 & 30 oo & 27000 \\
\hline$\cdots \cdots \cdots \cdots \cdots \cdots \cdots \cdots \cdots \cdots \cdots \cdots \cdots \cdots \cdots \cdots \cdots \cdots \cdots \cdots \cdots$ & 50 & 450 & 4000 & 350 oo \\
\hline$\ldots \ldots \ldots \ldots \ldots \ldots \ldots \ldots \ldots \ldots \ldots \ldots \ldots \ldots \ldots \ldots \ldots$ & 65 & 550 & 45 oo & 40000 \\
\hline 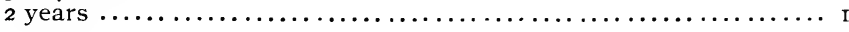 & I OO & 850 & 7500 & 600 oo \\
\hline  & 50 & & IOO OO & \\
\hline
\end{tabular}

\section{Trees on Citrus Trifoliata Stock}

Citrus trifoliata is the hardiest species of Citrus known in this country. It is deciduous, grows well in the open ground as far north as Washington, D. C., and withstands temperatures of $I 5^{\circ}$ below zero and lower. 


\section{GLEN SAINT MARY NURSERIES}

\section{Citrus Fruits}

It has become of great importance as a stock for citrus trees of all kinds. Varieties budded on it are made hardier because of its dormant and hardy character, and the fruit is of exceedingly fine quality, ripening two or three weeks earlier than if budded on other stocks. It has been claimed that it dwarfs the trees budded upon it, but the tests of years in our test-groves have not proven this to be so except in the case of a few varieties. For the Satsuma orange, it is the only stock to use.

Citrus trifoliata is adapted for planting on alluvial lands, clay lands, soils underlaid with clay and those which naturally contain plenty of moisture or to which water can be applied by irrigation. It should not be planted on high, dry, sandy lands lacking in moisture. On such soils it is a failure.

Seedlings can be used as a hedge, and it forms an impenetrable barrier to man or beast and, with proper care, can be made rabbit-proof.

We do not attempt to propagate all our varieties on Citrus trifoliata, and carry only a select list of those varieties which our experience has proven will give satisfaction on this stock. Our list of varieties is as follows, though we can supply a few trees of nearly all varieties in our list on special request: Boone's Early, Dugat, Jaffa, Magnum Bonum, Mandarin, Nonpareil, Old Vini, Parson Brown, Pineapple, Ruby, Satsuma, Tangerine and Washington Navel Oranges, Duncan and McCarty Grapefruit, Kenedy, Villa Franca and Ponderosa Lemons, Marumi aná Nagami Kumquats.

PRICES ON SATSUMA AND OTHER ORANGES.-On Citrus trifoliata Stock.



PRICES ON CITRUS TRIFOLIATA SEEDLINGS.

Each Per ro $100 \quad \mathrm{I}, 000$

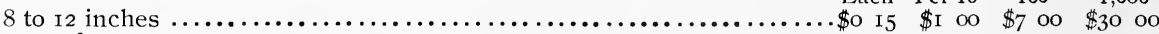





For prices on Pomelos, Lemons and Kumquats, see under these fruits.

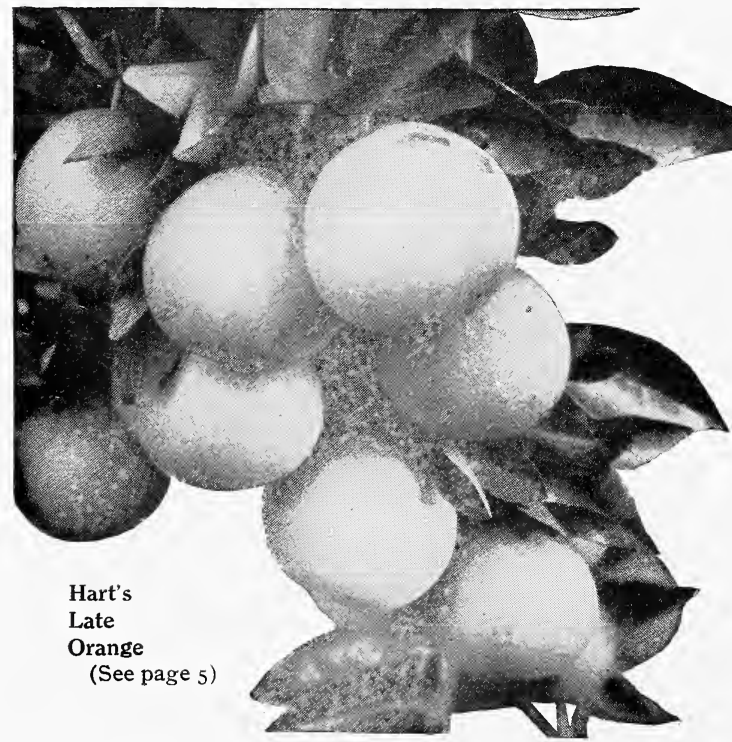

4

\section{ORANGES}

In order of ripening, varieties may be arranged about as follows : Very early-Boone Early, Satsuma, Sweet Seville. Early -Centennial, Dugat, Enterprise Seedless, Golden Buckeye Navel, Golden Nugget Navel, Nonpareil, Parson Brown, Surprise Navel, Thomson Improved Navel. Medium-Du Roi, Homosassa, Jaffa, Madam Vinous, Magnum Bonum, Majorca, Maltese Blood, Mandarin, Old Vini, Oneco, Pineapple, Ruby, St. Michael Blood, Tangerine, Washington Navel. LateMaltese Oval, Mediterranean Sweet, Navelencia, Paper Rind. Very lateBessie, Brazilian, Hart Late, Joppa Late, King, Valencia Late, Lamb Summer. Blood markings do not appear till late in the season. Some varieties hang on the tree and improve in quality after they first become marketable.

Bessie. Medium-sized; skin thin, but tough and firm; juicy and fine-flavored. One of the most profitable of the late 


\section{GLEN SAINT MARY NURSERIES}

Citrus Fruits

sorts. Holds in perfection until May. Tree vigorous and productive.

Boone (Boone's Early). Medium size ; good quality. One of the most valuable extremely early varieties. Unlike most early varieties, it colors up as soon as ripe.

Brazilian. A variety as yet comparatively little known by Florida orange-growers, but highly recommended for vigor and productiveness. Fruit of very fine quality and hangs upon the tree without deterioration until midsummer.

Centennial. Ripens early, but hangs on the tree well, and is of fine quality late in the season. Is a vigorous grower and prolific bearer.

Dugat. This variety has been grown in southern Texas for several years, where it is highly esteemed as one of the hardiest varieties and of excellent quality.

Du Roi. Medium-sized; slightly oblong; sometimes slightly ribbed; tine-grained, with but few seeds. Quality good.

Enterprise Seedless (Starke Seedless). Size medium; quality fine; seedless, or nearly so. Tree vigorous and productive. Early.

Golden Buckeye Navel. A recent California introduction, and is described as follows by the introducer: "The tree is a good grower, thornless. *** A pronounced characteristic of the fruit, which makes it distinct from all other varieties of Navels, is a series of bands or ridges of a deeper orange-color, which add much to the beauty. *** Smooth and of a kid-glove texture. Flavor strongly aromatic, with a suggestion of pineapple to the taste ; pulp of fine texture, with but few segments, almost entirely free from rag. *** Good keeper and shipper.' Ripens early; seems to promise well, and to be worthy of careful trial in various sections.

Golden Nugget Navel. A new California variety for which the introducer claims some very desirable features. Tree is described as of distinct habit, very symmetrical, and foliage exceptionally dark green ; thornless. Fruit very smooth, solid, and thin-skinned; very much more so than Washington Navel, even at its best; of fine texture; color a strong gold; shape rather oblong, good size ; fruit exceptionally free from rag and is seedless ; flavor delicious ; bears young, generally second year from planting. A good shipper and keeper. Ripens early and ought to become valuable.

Hart (Hart's Late). Of medium size, round or slightly oval ; smooth; very solid and heavy, the flesh being very firm; quality good; peel of lightest cast; few seeds. The tree is very

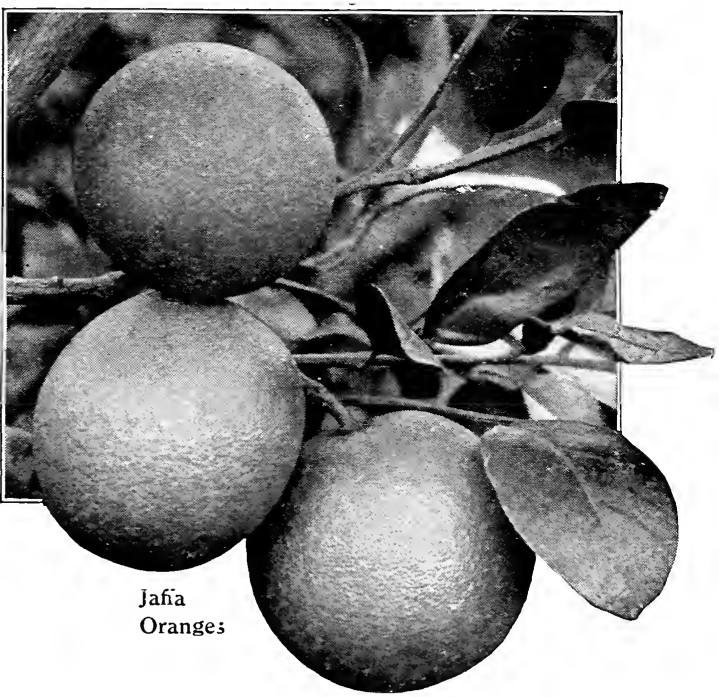

strong, spreading and vigorous grower, prolific; the foliage is distinct; but few thorns. Ripens in April ; hangs on the tree in good condition until midsummer. The best late variety for general planting.

Homosassa. Size about medium; round, somewhat flattened; very heavy; color bright; skin very smooth, thin, tough and dense; pulp fine sweet and juicy; flavor full, vinous and sprightly; membranes covering segments if pulp thin and small in quantity; keeps and carries well. Quality best. Tree vigorous and prolific.

Jaffa. Medium to large; peel thin; pulp melting, scarcely any fiber; juicy, rich and of exquisite flavor. In quality uusurpassed, being one of the four or five varieties which head the list in all competitions. The fruit remains on the tree in prime condition for a long period. The tree is a strong, upright grower of distinct habit, practically thornless, and a prolific bearer when it has attained sufficient size to hold good crops.

Joppa Late. This variety was originated by Mr. A. B. Chapman, of San Gabriel, Cal., from seed obtained in Joppa, Palestine. An extremely late orange-said to be even later than Hart's Late. Tree upright, vigorous grower and thornless. Fruit medium to large ; oblong, with thin rind; few or no seeds ; pulp juicy and sweet.

King. Very large, flattened and with loosely adhering rind and segments; color orange-red; 


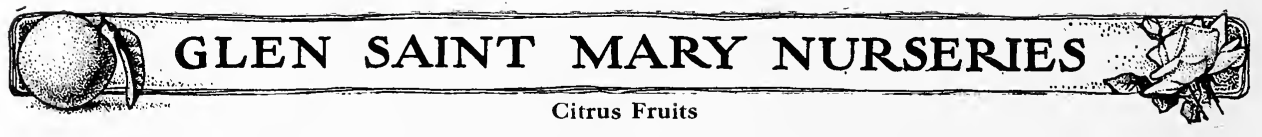

skin rough, but general appearance fine; its high and peculiar aromatic flavor is very agreeable; it has few seeds; flesh deep red-orange, juicy, meaty; inner lining of rind and membranes bright buff. Quality the very best. Tree upright, strong grower; quite thorny. March, April and May; keeps in good condition even later.

Lamb (Lamb's Summer). A medium-sized orange of fair quality, valuable chiefly on account of the time of ripening-during the summer, as its name indicates.

Madam Vinous. Medium to large; skin smooth and thin. Quality fine. One of the best of the numerous good varieties from the Indian river section of Florida. Ripens midseason.

Magnum Bonum. Size large to very large ; flattened; color light, clear orange; skin smooth and glossy ; color of flesh light ; grain very fine, tender and melting; fruit very heavy and juicy ; excellent shipper; quality best. Tree prolific and vigorous.

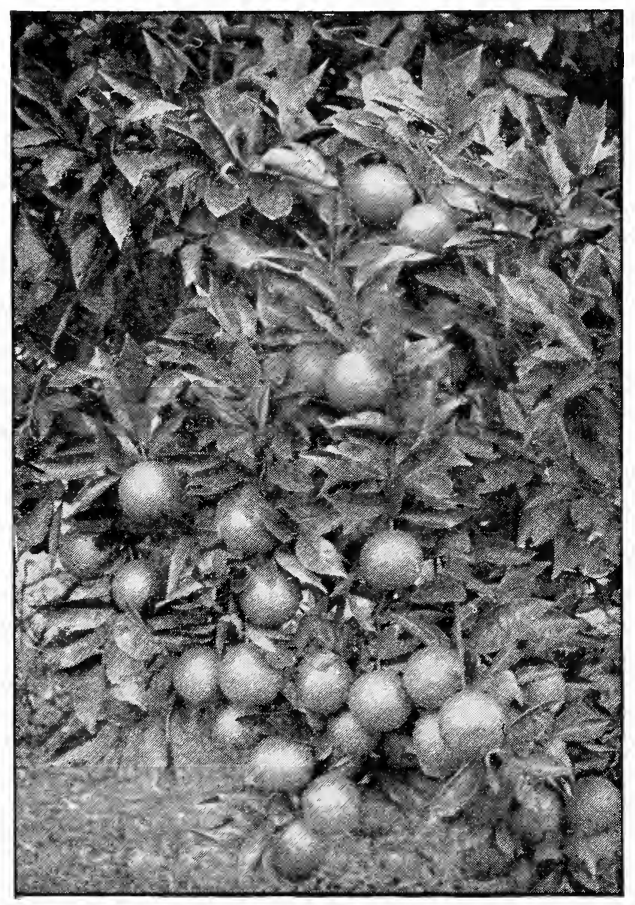

Pineapple Oranges (see page 7)
Majorca. Medium size; round; rich, juicy and sweet; equals Jaffa in quality, its characteristics being similar to that variety. It is a good keeper and shipper. Tree a strong, bushy grower, very robust; foliage very distinct; nearly thornless; a fine bearer.

Maltese Blood. Fruit medium in size; round or slightly oblong; skin very smooth, thin and tough; very juicy, sweet and sprightly; good in December, but better in April; a good shipper. Tree prolific and vigorous ; practically thornless; foliage distinct.

Maltese Ova 1 (Garey's Mediterranean Sweet). Fruit medium to large; quality firstclass; ripens medium to late. Tree of distinct spreading growth, vigorous and prolific.

Mandarin. Medium size, flattened; deep yellow; skin thin; segments loosely adherent; flesh dark orange-yellow, spicy and aromatic. Although largely superseded in Florida by other Mandarin oranges, yet in southern Louisiana the Mandarin is still planted as one of the most profitable sorts.

Mediterranean Sweet (Sanford's). Large size; smooth rind. Quality good. Ripens late. One of the best of General Sanford's introductions.

Navelencia. A comparatively new variety of California origin. Said to be a cross between Thomson's Improved Navel and Valencia Late, combining the good qualities of the former and lateness of the latter. Ripens 30 to 60 days later than Washington Navel. Tree of good growth, small thorns, full, well-rounded top. Fruit goodsized, smooth and thin-skinned, and of fine quality; gives promise of being a valuable acquisition.

Nonpareil. Size medium to slightly larger, somewhat flattened; grain fine, pulp melting and tender; juice subacid and vinous ; quality best. Tree vigorous and prolific. A very desirable early variety.

Old Vini (Beach No. 4). Size medium, slightly flattened; color dark orange ; pulp melting; juice subacid; pleasant sprightly quality.

Oneco. Of full, medium size for the Mandarin type. The color of skin is red, like Tangerine, and it also possesses a decided Tangerine aroma. The fruit is of good quality and reminds one of Satsuma, Tangerine and King blended.

Paper Rind (St. Michael). Fruit medium size, round; quality good; productive. Tree a vigorous grower.

Parson Brown. Size medium, round or slightly oblong; peel smooth, texture fine; quality good. Keeps and ships well. One of 




Satsuma Oranges

the best of the early varieties. Begins to ripen in October.

Pineapple. A most excellent variety, which has, during recent years, attained, and very justly so, a great amount of prominence. The tree is a very strong, upright grower; prolific. Fruit medium to large; peel thin but tough, very smooth and bright; heavy, fuicy and of excellent quality. We consider this one of the best round Oranges and recommend it as one of the most profitable sorts for extensive planting.

Ruby. Medium-sized, nearly round; skin thin but very tough; pulp melting, rich, juicy and of exquisite flavor; quality unsurpassed. As the fruit ripens it usually becomes streaked or mottled with blood-red; often the entire pulp gets ruby-red, showing through the peel in a reddish blush on the outside. Ruby is the best of the Blood Oranges, and its eating quality is good before the markings show. The tree is vigorous, nearly thornless, and a regular bearer. We esteem this one of the most valuable varieties for general planting.

St. Michael Blood. One of the best of the Blood Oranges. Fruit medium size, almost round, with thin but tough skin; pulp juicy, melting, rich and of exquisite flavor, being unsurpassed in quality. Usually the fruit becomes mottled or streaked with blood-red as it ripens, the pulp often a beautiful, rich ruby-red, showing through the peel in a reddish blush. Is a regular bearer, vigorous and nearly thornless.
Satsuma (Synonyms. Oonshiu, Kii Seedless). Of medium size; flattened; loosely adhering rind and easily separated segments like all other varieties of the Mandarin (Citrus nobilis) group; the color is a deep yellow; flesh fine-grained, tender, juicy, sweet and delicious; entirely seedless. Ripens in September, October and November. Tree of somewhat smaller growth than other Oranges, and is of unique habit. Entirely thornless. Bears when very young. This is undoubtedly the hardiest known variety of edible Orange, and this, in connection with its early ripening and fine quality, makes it an exceedingly valuable sort. We are growing it largely in our own Orange groves at Glen Saint Mary, in northern Florida, and are probably the largest propagators of this variety in America. Then budded on Citrus trifoliata it is the best variety for general planting throughout northern Florida and the Gulf coast Orange region generally.

Surprise Navel. Originated by Mr. E. S. Hubbard, of Federal Point, Fla. Size medium; navel mark small, but very distinctive. Very heavy, smooth, thin-skinned, and nearly seedless. Quality good. Ripens early. Claimed to be a heavy bearer, even when budded on sour stock, and is believed to be quite an acquisition to the list of Oranges; worthy of careful trial.

Sweet Seville (Sanford's). Size medium, round; a good keeper and shipper; sweetens first of the early kinds, and is known distinctly as a sweet Orange. Tree vigorous and prolific. 


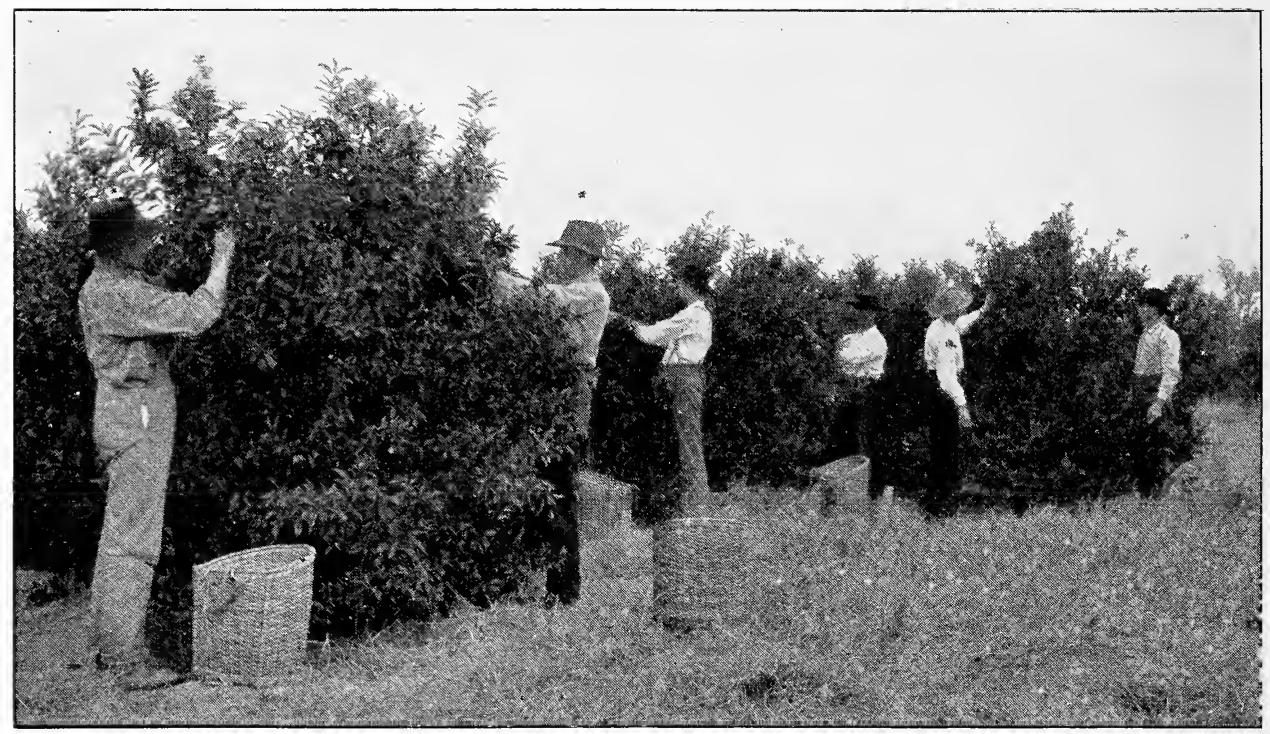

Gathering Kumquats at Glen Saint Mary Nurseries

Tangerine (Dancy's). One of the well-known "kid-glove" Oranges; belongs to the Mandarin group. Flat, small to medium; skin separates freely from the flesh; juicy, aromatic and rich, of a deep red color. Particularly good grower and prolific. December, January and February.

Thompson Improved Navel. This variety has been attracting considerable attention in California, where it was originated. Fruit of medium size, rind very smooth and thin; pulp juicy, sweet, and of firm texture. Ripens early. Tree similar to Washington Navel.
Valencia Late. A very late and very prolific variety of fine quality. Season May and June, but fruit will hang on trees till August or September. Fruit of good size, oval or rounded in shape; juicy and tender.

Washington Navel. Like other Navels, bears a peculiar umbilical formation on the summit or blossom end of the fruit; this protuberance is not so prominent as in some varieties of Navel Orange. The fruit is large to very large, somewhat oval; flesh meaty, tender, sweet and highly flavored; an exceptionally luscious fruit.

\section{KUMQUATS}

The Kumquat, or Kin-kan (Citrus Japonica), the smallest of the Citrus family, is a hardy shrub, reaching a height of ro to 5 feet. A handsome plant, with dark foliage and golden fruit.

Kumquats equal the Satsuma orange in hardiness, and should be planted with it. On Citrus trifoliata stock, it will withstand a temperature of is degrees $F$. without injury. The fruit sells at a fancy price, $\$ 6$ to $\$$ Io per crate, and, if carefully marketed, it is a very profitable fruit to grow. The fruits should be picked with leaves attached, packed tastefully in quart baskets, and shipped in strawberry crates. They are eaten without removing the rind, and make excellent preserves, marmalades, jellies and crystallized fruit. We propagate only on Citrus trifoliata and Rough Lemon stock, as they do not grow well on Sweet or Sour Orange roots.

PRICES ON KUMQUATS.-On Citrus trifoliata and Rough Lemon stocks.

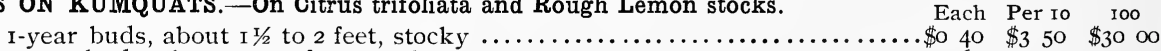

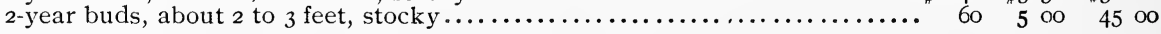

Nagami. Fruit oblong, about $\mathrm{I} / 2$ to 2 inches in length and $\mathrm{I}$ inch in diameter; fruit golden yellow; rind sweet; pulp and juice sprightly, of fine flavor. Tree forms a nice head and grows quite symmetrically; a little more open than the Marumi but still compact. Leaves are a trifle larger than the Marumi variety.

Marumi. Fruit round, about one inch in diameter, bright golden yellow. Rind sweet, with a pleasant flavor, and pulp and juice sprightly; quality very fine. Tree forms a beautiful, well-rounded, symmetrical head, even when quite young, and always retains this shape. Tree a little more compact than $\mathrm{Na}$ gami. Begins to ripen two to three weeks before Nagami. 


\section{GLEN SAINT MARY NURSERIES}

Citrus Fruits

\section{LEMONS}

Villa Franca. Medium size ; rind smooth, thin and sweet ; juicy ; acid very strong and of fine quality; tree has but few thorns and is a vigorous grower and very productive. Fruit a good shipper. One of the very best; has taken first rank in many competitive exhibits.

PRICES ON VILLA FRANCA.-On Sour Orange and Rough Lemon stocks.

... So $35 \quad \$ 3$ 00 $\quad \$ 2500$





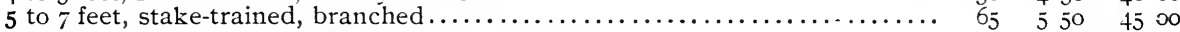

PRICES ON VILLÅ FRANCA LEMON.-On Trifoliata stock.



2 to 3 feet, stake-trained, straight stems $\ldots \ldots \ldots \ldots \ldots \ldots \ldots \ldots \ldots \ldots \ldots \ldots \ldots \ldots \ldots$ 45 $400 \quad 3500$

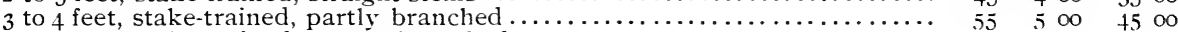

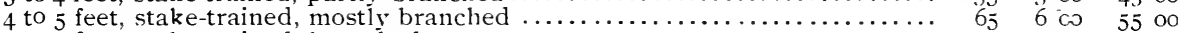

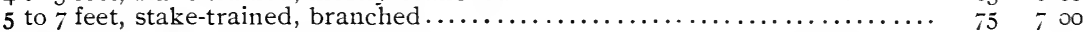

Donaldson. We introduced in Igog to our customers a new variety of Lemon named Donaldson. The fruits of this variety are very large, weighing $\mathrm{I}$ to 2 pounds. and of the same shape and color as the smaller Lemons. The acid is clear and strong, and the fruit is exceptionally fine for home use. The tree is a strong, hardy grower, and we have no hesitation in recommending it for planting.

Ponderosa Lemon. An exceptionally large Lemon, fruits weighing from $1 / 2$ to $21 / 2$ pounds ; very juicy, excellent quality, genuine lemon flavor. Rind very thin for such large fruit. Bears when quite young. Tree quite similar to other lemons in appearance and about as hardy.

PRICES ON DONALDSON AND PONDEROSA.-On Sour Orange and Citrus trifoliata stock. Each Per ro

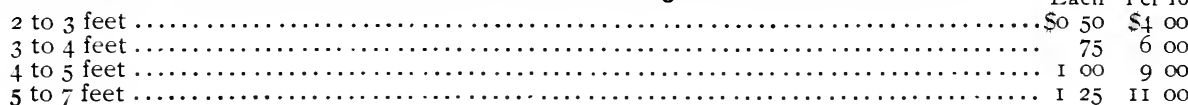

\section{POMELO (Grape Fruit)}

Year by year the Pomelo is steadily gaining in public favor. More of the fruit is consumed than ever before, and still the demand is increasing. It has become the breakfast fruit of America.

To the planter of citrus trees, the Pomelo commends itself because it comes into bearing early and bears extremely heavy crops. It is not too much to say that Pomelo trees will bear more fruit per tree than any other citrus.

We have given particular attention to the growing of Pomelo trees for many years. In our test grove we have the different varieties in fruit and are, therefore, in position to speak definitely concerning their merits and to know definitely that our stock is genuine.

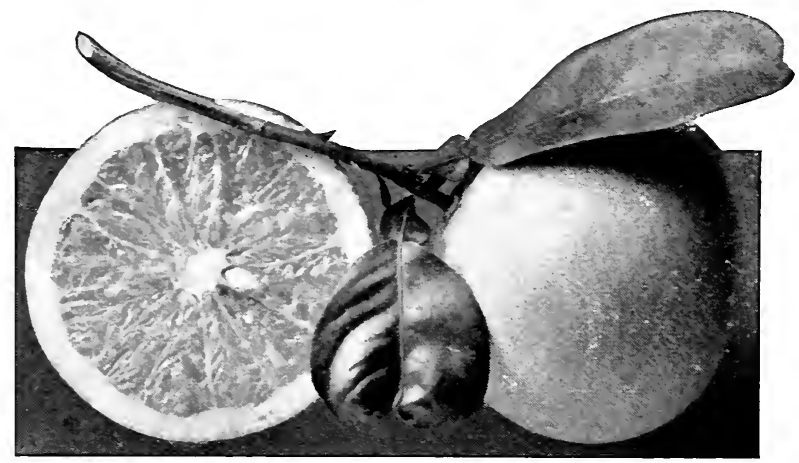

Marsh Seedless Pomelo

PRICES ON POMELO.-On Sour Orange and Rough Lemon stocks.

2 to 3 feet, stake-trained, straight stems

Each Per io Ioo 3 to 4 feet, stake-trained, partly branched $\ldots \ldots \ldots \ldots \ldots \ldots \ldots \ldots \ldots$

4 to 5 feet, stake-trained, mostly branched $\ldots \ldots \ldots \ldots \ldots \ldots \ldots \ldots \ldots \ldots$

to

5 to 7 feet, stake-trained, branched

350

450

$\$ 2500$

3000

to oo

4500

I.OCO

$\$ 22000$

27000

3.50 oo

40000 


\section{GLEN SAINT MARY NURSERIES}

Citrus Fruits

PRICES ON DUNCAN POMELOS.-On Trifoliata Stock.

Each Per io 100

I to 2 feet, stake-trained, straight $\ldots \ldots \ldots \ldots \ldots \ldots \ldots \ldots \ldots \ldots \ldots \ldots \ldots \ldots \ldots \ldots \ldots \ldots \ldots \ldots \ldots$

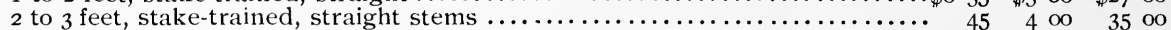

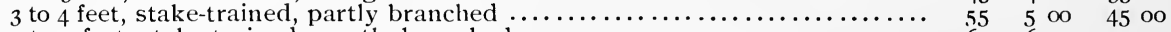

4 to 5 feet, stake-trained, mostly branched $\ldots \ldots \ldots \ldots \ldots \ldots \ldots \ldots \ldots \ldots \ldots \ldots \ldots . \quad 65 \quad 6$ oo 55 oo

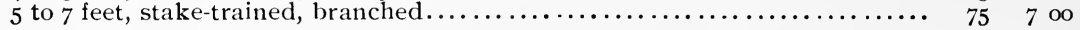

Duncan. Of large size; peel tough and smooth. Quality very best; regular old-fashioned Grape Fruit flavor. Strong grower and regular and prolific bearer. We recommend this variety without the slightest hesitation as being one of the finest, also one of the hardiest varieties. Hangs on trees and keeps in fine condition until late spring or early summer. See front cover page for illustration in actual color.

Hall (Hall's Silver Cluster). Medium to large, nearly round. Good quality, heavy bearer, large bunches.

Marsh Seedless. Large size, slightly flattened; skin very smooth; heavy, juicy and of excellent quality. Nominally seedless, it generally has a limited number of seeds. Desirable.

Pernambuco. A large grape-fruit with very smooth light-colored skin. A good bearer.
The fruit is of excellent quality and handsome appearance. It ripens late and hangs on the trees well. This variety was imported from Brazil by the United States Department of Agriculture, a number of years ago.

Tresca. Fruit of large size and fine appearance. Pulp rose-colored and of fair quality. Introduced from the Bahamas.

Triumph. Medium size; skin smooth; heavy; juicy, well-flavored; less bitter than some others. A strong grower, prolific. This is the earliest variety of grape-fruit we have, and for home use and for some markets it is excellent. It cannot be recommended for planting in the colder sections, as the tree is tender. The fruit does not run large enough to suit many growers, but we esteem it highly for its season.

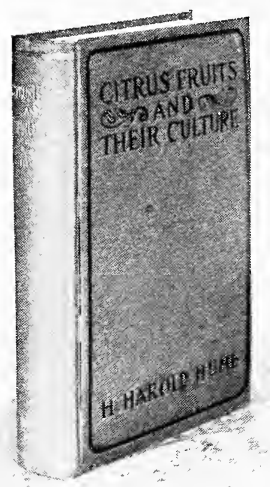

\section{LIMES}

Limes can be put to all the uses for which the lemon is adapted. The flavor is different from that of the lemon, but is highly appreciated by every one who has used the fruit. In tropical countries they are in more general use than lemons.

Lime trees are vigorous growers and in suitable climates bloom and bear continuously throughout the year. It must be remembered that Limes are very tender trees and should not be planted in sections subject to hard frosts. For this reason we are growing them only on sour orange and rough lemon stocks. They grow well under very adverse conditions.

Persian Lime. Large size, about the same as an ordinary lemon. smooth, very juicy, with strong, clear acid. Tree strong grower and good bearer. A desirable Lime.

PRICES ON PERSIAN LIMES.-On Sour Orange and Rough Lemon stocks.

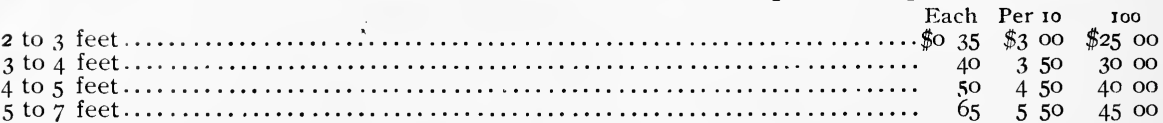

\section{Citrus Fruits and Their Culture By H. HAROLD HUME}

This work is heartily endorsed by the leading growers of citrus fruits. The subject of citrus fruit-growing is thoroughly covered in all its phases, from the preparation of the land and the planting of the trees to the marketing of the fruit. For the grower engaged in the production of first-class oranges, pomelos (grape-fruit) or lemons, it is an invaluable book. It contains 597 pages, well illustrated with line drawings and half-tone engravings. Price, postpaid, $\$ 2.50$. 


\section{GLEN SAINT MARY NURSERIES}

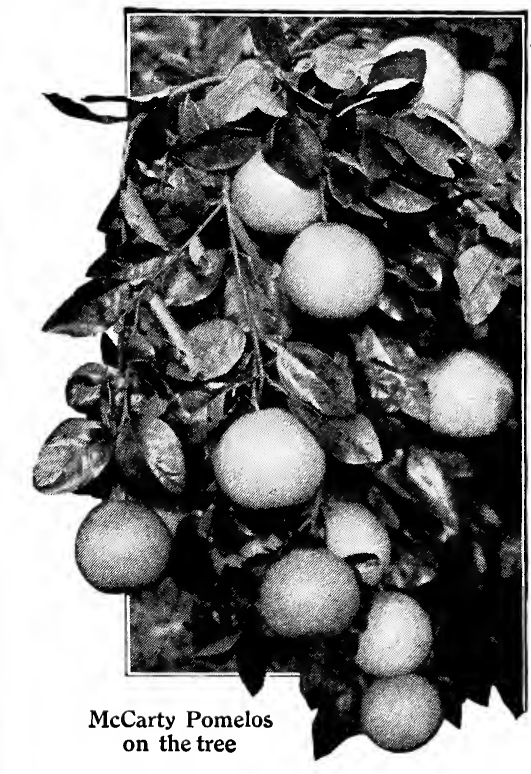

Citrus Fruits

\section{New Pomelo, McCarty \\ THE POMELO THAT BEARS ITS FRUITS SINGLY}

For many years we have had under observation a Pomelo of , the famous Indian River strain, a late-maturing variety of unsurpassed quality. The fruit is waxy, yellow color; of large size, packing 48 to 64 per box. The tree is vigorous, healthy and prolific. The striking peculiarity of the variety is that the fruit, almost entirely, is borne not in bunches, but singly, and well distributed over the tree. This is a valuable feature.

The flavor is a perfect blending of sweet, acid and bitterness, the true Pomelo flavor. The flesh is melting, free from fiber and rag; seeds about the usual number.

We have named the variety McCarty, in honor of the late Mr. C. T. McCarty, one of Florida's most noted horticulturists. The original tree is growing at the McCarty home at Eldred, Florida, and we believe it to be well worthy of his name.

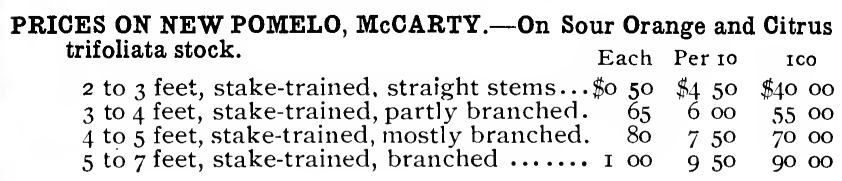

\section{New Lemon, Kenedy}

\section{A LEMON ALL JUICE AND THE JUICE ALL ACID}

This fine Lemon originated on the ranch of Mr. John G. Kenedy, Sarita, Texas. In the winter of 1908, our President, Mr. G. L. Taber, visited the original tree and, with Mr. Kenedy's assistance and under his supervision, cut buds from the tree which Mr. Kenedy said was the best and should be known as Kenedy. Buds had already been cut indiscriminately from this and four other seedling lemons, and the whole mixed lot is now being grown and disseminated by ott.er nurserymen as Kenedy Lemon. We are pleased to be able to introduce the true variety of this name. It is a Lemon of good commercial size and considered hardy, quite or almost seedless, beautiful, smooth with very thin rind and solid flesh. The tree is prolific and thrifty.

We submitted specimens to Prof. W. A. Blair, Chemist of the Florida Experiment Station, who reported the fruit as containing $68.69 \%$ juice and $7.40 \%$ citric acid. This marks it as a Lemon of the very highest quality.

PRICES OF THE KENEDY LEMON.On Sour Orange and Citrus trifoliata stock.
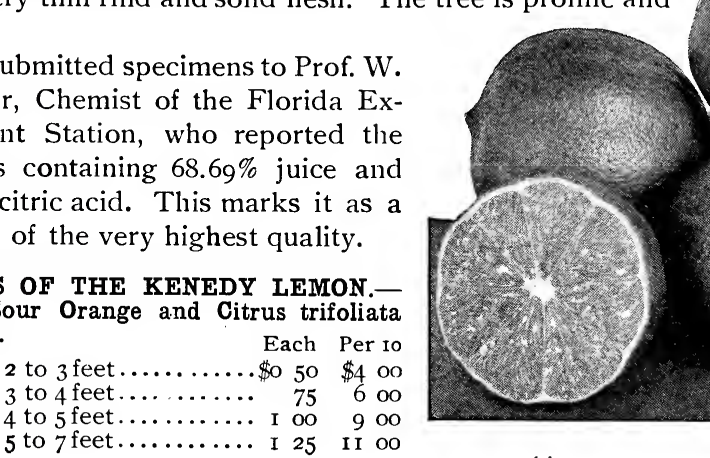

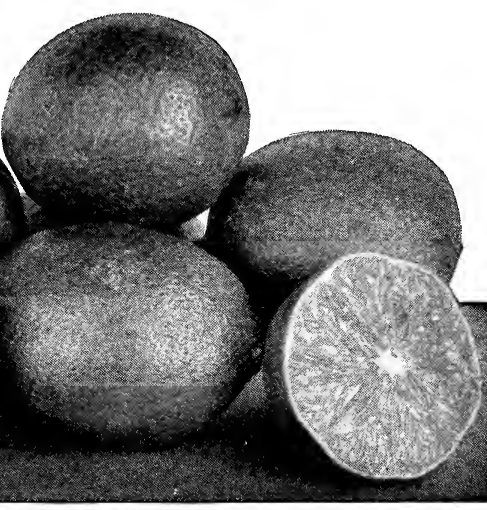

Kenedy Lemon 


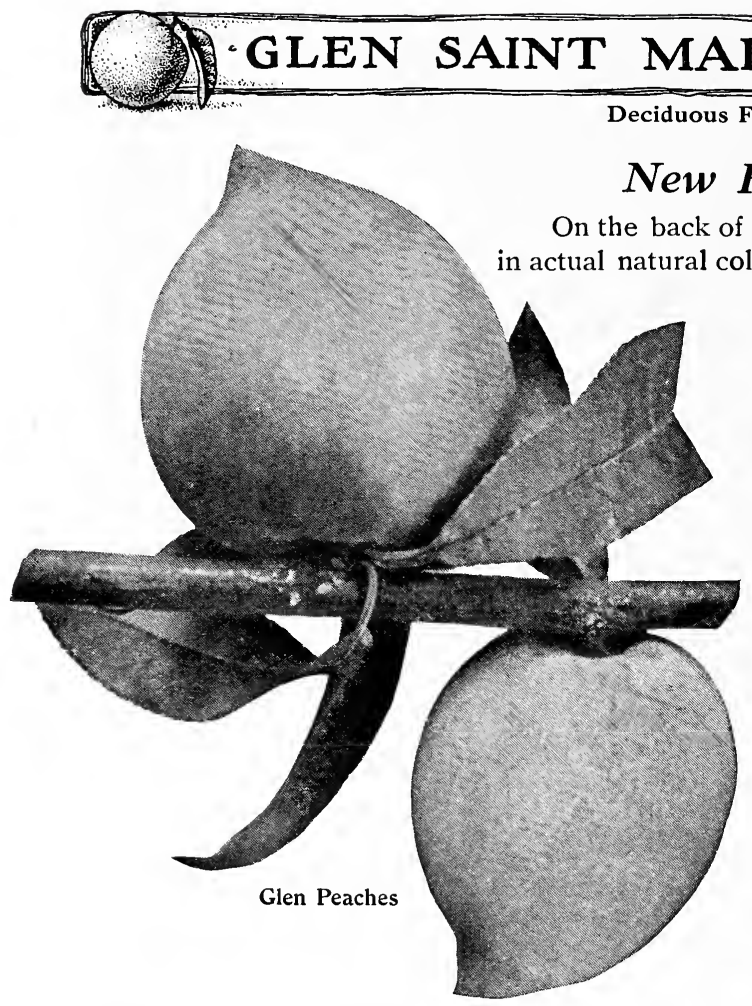

season, a new hybrid Plum-McRea, which we believe to be well worthy of extensive planting. The tree is vigorous, a heavy annual bearer. The fruit is of medium size, $I \frac{1}{4}$ to $I \frac{1}{2}$ inches in diameter, flattened, oblique at the apex, yellow in color, washed with dull red on the exposed parts, thickly dotted with small, light-colored dots. Bloom delicate and bluish in color. Flesh yellow, firm, becoming juicy; good shipper. Flavor subacid and quality very fine. Said to be a seedling of Kelsey. Ripens June so to 15 or later.

The McRea Plum originated near Lake City, Columbia county, in northern Florida, and was first brought to our attention by Mr. J. C. Bates. It is of the same type as Excelsior and Terrell, but quite different in flavor. It is believed to be a seedling of Kelsey, the variety which more than any other has given us splendid seedling plums, The tree is a strong grower, and bears well.

\section{PRICES ON MCREA PLUM.}

I-year, small size, 2 to 3 feet. $25 \mathrm{cts}$. each, $\$ 2$ for Io, \$I3 per Ioo.

I-year, medium size. 3 to 4 feet. 30 cts. each, $\$ 2$.5 for Io, \$16 per Ioo.

I-year, standard size. 4 to 6 feet. 40 cts each, $\$ 3$ for Io, $\$ 20$ per Ioo.

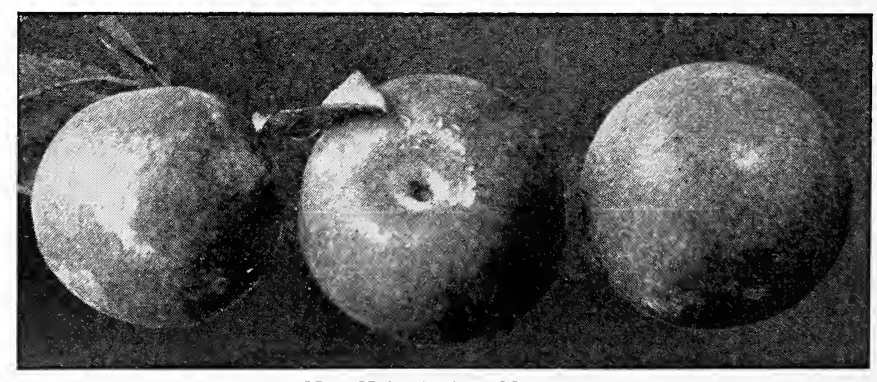

New Hybrid Plum McRea 


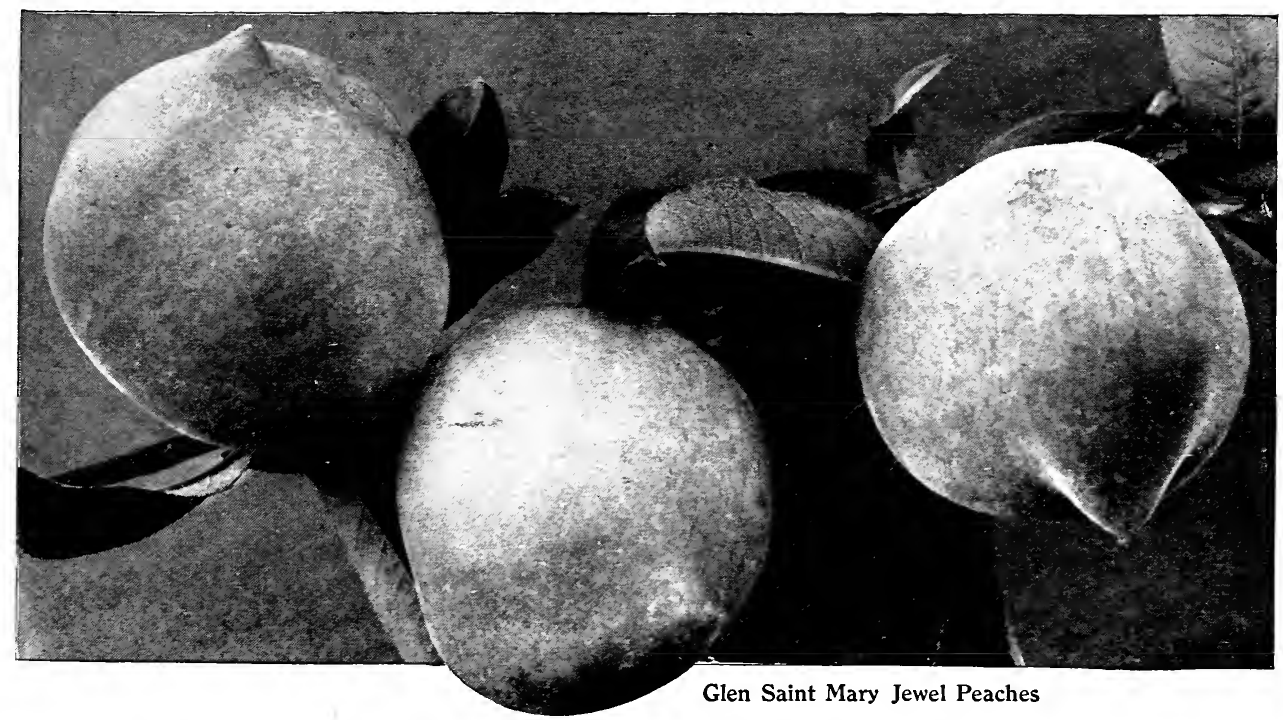

\section{PEACHES}

For twenty-seven years we have been studying Peaches. During this period, we have originated and introduced a large number of different kinds. We have throughout this period been growing nursery trees, and the trees which we are producing for our customers are better than ever before. Our land is particularly adapted to the growing of fine Peach stock, and we are able to offer our customers the best trees that can be produced. They are well-grown, true to name,-in short, "Quality trees" of the very best strains.

Varieties of Peaches should be carefully selected, to have them adapted to the section where they are to be planted. This done, good trees planted on new land with good drainage, and carefully cultivated, they bring quick returns, and are among the most satisfactory fruits that can be grown either for home use or for the market.

The types of Peaches are as follows: Persian, commonly planted in the North. Northern Chinese, which includes Elberta and related varieties, generally planted in the cotton-belt; well adapted to western Florida. Spanish, native varieties that have originated in Florida and in the Gulf Coast; adapted to the latitude of northern Florida. Honey, comprising the Honey and its seedlings, adapted to northern Florida, southern Georgia and westward around the Gulf. Peen-to, comprising the original Peen-to and the varieties originated from it; well adapted to Florida, tropical and subtropical regions. Jewel, is the most important commercial variety in the group. Oriental Bloods, Red Ceylon, adapted to the same range as Peen-to and Japan Dwarf Blood to the same territory as the Honey Peach.

\section{PRICES ON PEACHES.}

\begin{tabular}{|c|c|c|c|}
\hline Each & Per Io & 100 & $I, 000$ \\
\hline O I & $\$ I \quad 00$ & $\$ 8$ oo & 66000 \\
\hline I & I 20 & IO OO & 7500 \\
\hline & I 50 & 1200 & 9000 \\
\hline
\end{tabular}

\section{LIST TO AID SELECTION}

In assigning varieties to districts of wide area, there will be local exceptions, but the following lists are based on many years of somewhat extensive planting, experimenting, research and observation, and are as nearly accurate as we know how to make them.

Succession of Ripening.-The terms "very early," "early," "midseason" and "late," in the following list (as indicated to the right of each variety by the abbreviations "VE," "E," "M," "L") indicate the comparative ripening time of the variety. 


\section{Deciduous Fruits}

Explanation of List. - The varielies best adapted and most valuable for market in a particular section are printed in capitals, thus: "ANGEL." Varieties next in order of merit are printed in small capitals, thus: "Chrmax." Other varieties recommended are printed in lowercase type, thus: "Countess."

\section{LIST A.-Peaches for South Florida, West Indies and Other Subtropical and} Tropical Sections

ANGEL

BIDWELL'S EARLY

BIDWELL'S LATE

Cabler's Indian

ClimaX

COLON

Countess

DOROTHY N.

Estella

Florida Crawford

Admiral Dewey

ANGEL

BIDWELL'S LATE

CABLER'S INDIAN

Climax

COLON

Countess

DOROTHY N.

ESTELLA

Everbearing

FLORIDA CRAWFORD

\begin{tabular}{l|l} 
E & FLORIDA GEM \\
VE. & GEN ERAL HARRISON \\
E. & Gibbons' October \\
M. & HALL'S YELLOW \\
E. & HONEY \\
E. & IMPERIAL \\
M. & Japan Dwarf Blood \\
M. & JEWEL \\
L. & MAGGIE \\
M. &
\end{tabular}

\begin{tabular}{l|l} 
E. & PEEN-TO \\
M. & Powers'September \\
L. & RED CEYLON \\
E. & SUBER \\
E. & TABER \\
E. & TRIANA \\
VE. & Victor \\
VE. & Victoria \\
VE. & WALDO
\end{tabular}

VE.

L

VE.

$\mathrm{VE}$.

E.

E.

$\mathrm{VE}$

LE.

\section{LIST B.-Peaches for Eastern North Florida

\begin{tabular}{l|l} 
E. & Pallas \\
M. & Peen-to \\
M. & POWERS' SePtember \\
L. & SUBER \\
E. & TABER - \\
E. & Thurber \\
E. & TRIANA \\
VE. & VICTOR \\
VE. & VICTORIA \\
M. & WALDO
\end{tabular} \\ E. \\ VE. \\ LE. \\ E. \\ M. \\ E. \\ VE. \\ L. \\ VE.}

LIST C.--Peaches for West Florida and Lower Georgia, Alabama and Mississippi

ADMIRAL DEWEy

ALEXANDER

Angel

BeAuTy's Blush

BELLE OF GEORGIA

CABLER'S INDIAN

CARMAN

Chinese Ciring

Crimax

COLON

Countess

CRAIVFORD'S EARI,Y

CRAWFORD'S LATE

ELBERTA

ESTELLA

\begin{tabular}{l|l} 
VE. & Everbearing \\
VE. & Fleitas \\
E. & FLORIDA CRAWFORD \\
V. & FLORIDA GEM \\
M. & FRANCES \\
M. & GENERAL LEE \\
E. & GIBBON'S OCTOBER \\
M. & GREENSBORO \\
E. & HONEY \\
E & IMPERIAL \\
M. & Japan Dwarf Blood \\
E. & JESSIE KERR \\
M. & Jewel \\
M. & MAMIE ROSS \\
L. &
\end{tabular}

E. to $\mathrm{L}$.

$\mathrm{E}$.
$\mathrm{E}$.

M. Powers' September

M. SNEED

L. TABER

VE. THURBER

E. TRIANA

E. TRIUMPH

VE. VICTOR

VE. VICTORIA

VE. Waddell

E. Waldo
LE.

M.

E.

L.

VE.

E.

M.

E.

VE.

VE.

L.

VE.

\section{LIST D.-Peaches for Coastwise Texas and Louisiana}

\author{
Admiral Dewey \\ ALEXANDER \\ A NGEL \\ BEAUTY's BLUSH \\ Belle of Georgia \\ BIDWELL'S LATE \\ CABLER'S INDIAN \\ CARMAN \\ Chinese Cling \\ CLIMAX \\ COLON \\ Countess \\ Crawford's Early \\ Crawford's Late \\ ELBERTA
}

\begin{tabular}{l|l} 
VE. & ESTELLA \\
VE. & Everbearing \\
E. & Fleitas \\
E. & FLORIDA CRAWFORD \\
M. & FLORIDA GEM \\
E. & FRANCES \\
M. & GENERAL LEE \\
E. & GIBBONS OCTOBER \\
M. & GREENSBORO \\
E. & HONEY \\
E. & IMPERIAL \\
M. & Japan DWarf Blood \\
E. & JESSIE KERR \\
M. & JEWEL \\
M. & MAMIE ROSS
\end{tabular}

\begin{tabular}{l|l} 
L. to & MATTHEIV' BeAUTY \\
E. & ONDERDONK \\
M. & ONIEDO \\
E. & PALLAS \\
M. & SNEERS' SEPTEMBER \\
M. & TABER \\
L. & THURBER \\
VE. & TRIANA \\
E. & TRIUMPH \\
E. & VICTOR \\
VE. & VICTORIA \\
VE. & Waddell \\
VE. & WALDO \\
E. & \\
&
\end{tabular}

M.
M.
E.
E.
L.
VE.
E.
M.
E.
VE.
VE.
L.
E.
VE. 


\section{GLEN SAINT MARY NURSERIES}

Deciduous Fruits

\section{LIST E.-Peaches for Other Sections of the United States}

Adapted to most of the Peach sections of the country outside of the regions previously listed.

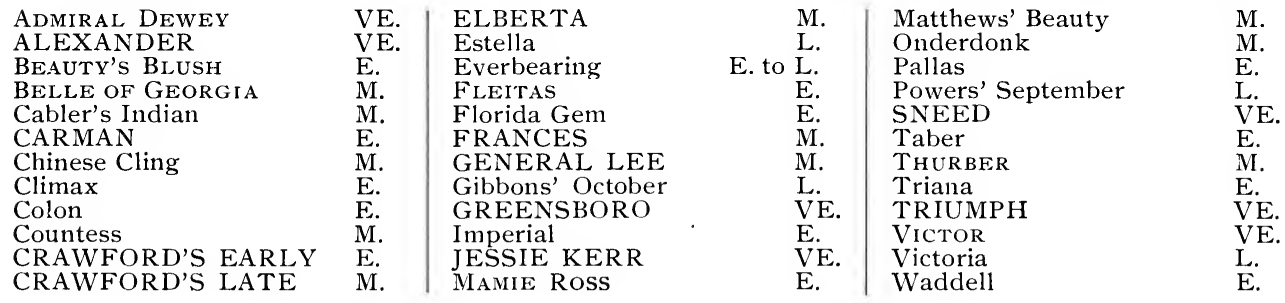

\section{VARIETIES OF PEACHES DESCRIBED}

The abbreviations in parentheses below, following the names of varieties, indicate the race to which they belong. Thus, (Sp.) means that the variety belongs to the Spanish race; (Per.), to the Persian race; (N. C.), Northern Chinese; (Hon.), Honey; (P-to), Peen-to; (O. B.), Oriental Bloods. The dates given for the usual time of ripening are based on northern Florida.

Admiral Dewey. (Per.) Fruit of good size; skin deep orange-yellow, with crimson cheek ; llesh clear yellow to the stone, juicy, melting, vinous; quality very good. June I to Io.

Alexander. (Per.) Large; highly colored; flesh greenish white, juicy, vinous, of fair quality; cling. One of the earliest of the Persian type. About June I.

Angel. (P.-to.) Large, rounded, slightly pointed; color yellow, washed with red, very handsome: flesh white, sweet, melting, juicy, subacid, of exquisite flavor, entirely lacking in bitter almond flavor; freestone. The tree bears while young, and is very prolific. It blooms a month later than Peen-to, thus escaping injury from frost in many sections. Highly recommended. June 20 to 30.

Belle of Georgia. (N. C.) Very large; skin white, with red cheek; flesh white, firm and of excellent flavor; fruit uniformly large and showy; free. Rapid grower, prolific. July I to I 5 .



Angel Peach

Bidwell's Late. (P.-to.) A seedling of Peento, originated at Orlando, Fla., and the best of the "Bidwell" varieties. Shape nearly round; size large; color yellowish white; flesh finegrained, sweet and juicy; clingstone. Matures about three weeks later than Peen-to. Quality excellent. This has proved a sure bearer farther north in Florida than most other varieties of the same origin, and is one of the most desirable sorts. 
Honey. (Hon.) Medium size, oval, compressed, with deep suture on one side, extending more than half way round, and terminating in a sharp, peculiar, recurved point; skin whitish yellow, washed and marbled with red in the sun; flesh creaniy white, fine, juicy, melting, with peculiar honeyed, rich, sweet flavor; quality excellent; free. June 5 to 20.

Imperial. (Hon.) Very large, roundish, oblong; skin greenish yellow, washed with red; flesh white, sweet, juicy, of excellent flavor and good tone; quality best; free. Originated by ourselves. June 25 to July 5 .

Japan Dwarf Blood. (O. B.) A blood freestone of good size and appearance and fair quality. Ripens earlier than Alexander. A dwarf-growing stocky tree.

Jessie Kerr. (Per.) A freestone, larger and earlier than Alexander, which it resembles in tree and fruit. Preferred to the latter by many orchardists. Adapted to the same sections as the Alexander.

Jewel. (P.-to.) Medium to large; rounded to oblung; highly colored, red on exposed parts ; flesh yellow, red about the pit, juicy, melting, sweet; excellent quality; freestone. Ripens about two weeks earlier than Waldo. A good shipper ; tree very vigorous and healthy. This is the most valuable market variety for southern Florida and all tropical and sub-tropical regions. It stands without an equal as the commercial market variety for these sections.

Maggie. (P.-to.) Size medium ; roundish oblong; skin yellowish white, washed with carmine; flesh fine-grained, sweet, juicy and melting; sub-cling. Ripens about with the Peen-to. Very much like Bidwell's Early in appearance, time of ripening and other qualities.

Mamie Ross. (N. C.) A seedling of the Chinese Cling, which it much resembles. Fruit almost as large as the Chinese Cling; white, nearly covered with delicate carmine; flesh white, juicy and of good quality. A regular and prolific bearer. Popular throughout Texas, where it is esteemed the finest early cling. June I5.

Matthews' Beauty. (N. C.) The fruit is of large size, shaped similar to Elberta, but a little longer; skin golden yellow, streaked with red; flesh firm, vellow and of excellent flavor. Ripens two or three weeks later than Elberta.

Mayflower. (Per.) Large ; well colored; red all over; of fine quality ; cling. A very promising variety. Its earliness, high color and excellent quality are strong points in its favor. Ripens four or five days earlier than Sneed.
Onderdonk. (Sp.) Large; skin and flesh yellow ; very juicy and sweet. Free. Originated in Texas. Possesses a valuable combination of quality, appearance and productiveness. A good midseason variety. Last of July.

Pallas. (Hon.) Good size, nearly round ; deep red, dotted with salmon and tipped with light yellow at the base and apex ; flesh white, fine-grained, melting, with a rich vinous aroma; quality excellent; free. Seedling of Honey. Succeeds well along the Gulf coast from Florida to southern Texas. June 20 to 30.

Peen-to. (P.-to.) A curiously formed Peach, flattened at both ends, with pit of the same shape; color greenish white, washed with red on exposed parts; flesh light yellow, sweet, rich, juicy, of good flavor, with a slight bitter-almond flavor; cling, with very small pit. Succeeds well in southern Florida. This variety and its seedlings are among the most tropical varieties of Peaches. Ripens in northern Florida May 20 to June 3 .

Powers' September. (Sp.) Fruit of medium size and good quality; flesh white, free. The tree is a good grower. A native variety of value on account of its lateness. Sept. I to I5.

Red Ceylon. (O. B.) A good-sized fruit of dull green color; flesh blood-red to the stone, from which it separates freely. It is not firstclass to eat out of hand, as it is too acid to suit most tastes, but it is a most excellent fruit for cooking, being possessed of a peculiar flavor when cooked, suggesting prunelles. This Peach is as unique in its way as the Peen-to and of an even more semi-tropical character. Tree a heavy and annual bearer in south Florida, and fruits well in Cuba.

Sneed. (N. C.) Very early, averaging eight to ten days earlier than Alexander. Fruit of medium size, somewhat oval in shape; color creamy white, with rich, red blush on sunny side; ripens evenly to the pit ; flesh white, very free and juicy; semi-cling. Of fine quality and not subject to rot, as are so many of the early varieties. A seedling of the Chinese cling, it has the vigor of its parents in tree growth and fruit-buds.

Suber. (P.-to.) Seedling of the Peen-to, originated at Lake Helen in southern Volusia county. It has been quite extensively grown for shipment by the growers of Lake Helen, by whom it is highly esteemed. Its description is not materially different from Bidwell's Early, except that it is larger, firmer and a little more acid than the latter. The tree is a vigorous grower and a satisfactory bearer, and the fruit brings a high price in maket. 


\section{GLEN SAINT MARY NURSERIES}

\section{Deciduous Fruits}

Taber. (Hon.) Large, roundish, oblong, pointed; skin white, overspread with red; flesh white, streaked with red; firm, very juicy, rich subacid; of fine quality ; cling. A seedling of Honey, a heavy bearer. Valuable for canning. June 15 to 25 .

Thurber. (N. C.) Large to very large; skin white, with light crimson mottlings ; flesh juicy ; vinous and of delicate aroma ; texture exceedingly. fine; free. Resembles Chinese Cling in size and color. Middle of July.

Triana. (Hon.) Medium to large, roundish oblong, slightly pointed; skin white, overspread with red; flesh white, with red markings, rich, juicy,

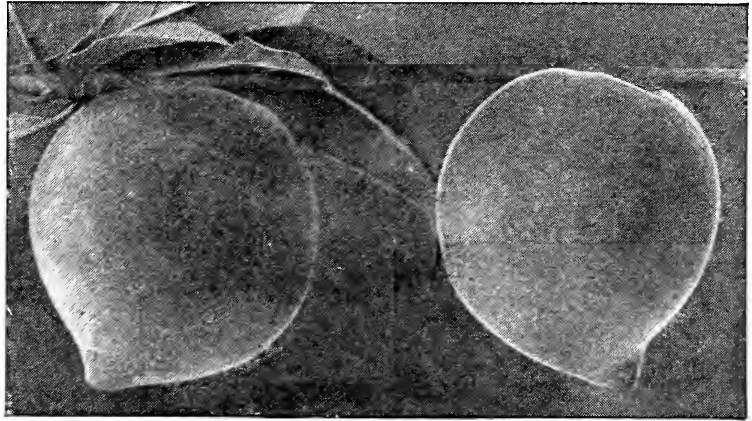

Waldo Peaches

which makes it undoubtedly the earliest variety in existence. Texas origin. May 8 to 16.

Victoria. (Sp.) Very large, nearly round ; skin yellow; Hesh yellow, juicy, sweet and of excellent flavor; free. One of the best varieties of native origin, well worthy of a place in every southern Peach orchard. Valuable for cooking and canning. August 5 to ro.

Waldo. (P.-to.) Size medium, round, oblong, highly colored, light yellow, dark red on exposed parts. Flesh yellowish white, red at the stone, juicy, melting, sweet, of excellent quality, freestone. Ripens with Peen-to. It is a free and regular bearer. Very valuable for Florida, Mexico, gulf sections of Texas and Louisiana, and has given very good satisfaction in the Vest Indian Islands.

\section{PLUMS}

In the extreme South, particularly in central and south Florida, southern Texas, and, in fact, all along the Gulf coast, the pure-bred Japanese varieties have not been good bearers, consequently were not generally profitable. But cross-bred varieties-Japanese varieties crossed with native varieties - have proven heavy annual bearers. These cross-bred varieties have made commercial Plum-growing not only possible, but worthy the attention of fruit-growers even in south Florida and northern Mexico. Of these cross-bred Plums, we can heartily recommend Excelsior, McRea and Terrell. These are excellent kinds and heavy bearers.

PRICES ON PLUMS.-On Marianna Plum stock.

\begin{tabular}{rrrrrr}
\multicolumn{2}{c}{ Each } & Per & 10 & \multicolumn{1}{c}{100} \\
.$\$ 0$ & 15 & $\$ 1$ & 30 & $\$ 10$ & 00 \\
. & 20 & I & 70 & 12 & 00 \\
. & 25 & 2 & 00 & 16 & 00 \\
. & 30 & 2 & 50 & 20 & 00
\end{tabular}

Abundance. Medium to large; round, with pointed apex; skin greenish yellow. ground, overlaid with dull purplish carmine; flesh light greenish yellow, juicy, sweet, with a touch of subacid and slight apricot flavor; pit small; cling; quality best. Strong grower, prolific. This is one of the most popular and profitable early sorts in the Plum-growing sections of the North, and in a wide area of the lower South.

Bartlett. New. We obtained this variety direct from Mr. Burbank. He describes it as follows: "Bartlett is the king for flavor; it outBartletts the Bartlett pear in exquisitely perfumed flesh ; bears when two years old." 


\section{GLEN SAINT MARY NURSERIES}

\section{Deciduous Fruits}


circumference, varying less in size than

Excelsior Plums

the other Japanese Plums ; it is nearly globular; clear cherry-red, sometimes showing yellow dots, or even marbled with a thin lilac bloom; flesh deep yellow, firm and meaty, rich and sugary, with a peculiar and very agreeable flavor; cling. Tree unusually vigorous, with strong, upright shoots and large, rather broad leaves. Very popular both North and South.

Chabot. Fruit large, about 2 inches in diameter, oblong-conical ; skin pink-red, with many very fine gold dots ; flesh yellow, very solid, rather acid; quality very good; cling.

Excelsior. This variety, originated by ourselves in I887 and first offered to the public in the winter of $I 89 I-92$, is worthy of extended notice. The tree is a remarkably rapid, strong grower and bears annually and abundantly. Fruit medium to large, $\mathrm{I} 1 / 2$ inches in diameter, nearly round, no suture ; color deep, solid, winered, with heavy light bluish bloom ; stem short, skin firm and without astringency; flesh firm, yellowish, with reddish color near the pit ; quality fine; clingstone. The earliest Plum to ripen in Florida ; about June I. Very handsome; fine shipper.

After many years of experimenting with numerous varieties of Plums, we do not hesitate to say that Excelsior and Terrell are the most satisfactory varieties for planting throughout the length and breadth of Florida, and throughout the Gulf-coast country, westward to the Rio Grande river. While adapted to this extreme range of latitude, we particularly recom-
Kelsey. Fruit very large, from 7 to 9 inches in circumference, heart-shaped, long-pointed, often lopsided, with deep, furrow-like suture; skin greenish yellow, sometimes overspread with bright red, with a lovely blue bloom; showy ; flesh light yellow, firm, meaty; quality excellent; free. Bears heavily, coming in young.

Persian Purple-leaved (Prumus Pissardii). Fruit medium to large, round; crimson inside and out; quality good, possessing a very decided cherry flavor; ornamental. June. Most desirable of the purple-leaved trees, retaining its vivid purple foliage until late in the season.

Red June (Red Nagate). Fruit medium to large, cordate and very prominently elongated; at the apex; suture deep, generally lop-sided; deep vermilion-red all over, with a handsome bloom; very showy; flesh light yellow or whitish ; firm, slightly subacid to sweetish, of good, pleasant quality ; cling to half-cling; pit small. Tree vigorous, productive.

Satsuma. Fruit, medium to large, broadly conical, with a blunt, short point, suture very deep ; skin very dark and dull red all over, with greenish dots and an under-color of brown-red; firm, very juicy; quality good; free. Flesh firm and solid, keeps in fine condition after being picked. Fine for preserving, and a grand keeper.

Wickson. Large, deep maroon-red; of the Kelsey type. Oblong-pointed; flesh firm, deep amber-yellow, clinging to the small pit. Of first quality. An excellent keeper. A good grower and heavy bearer. Valuable in the Plum-growing sections in the North, also good in lower South. 


\section{GLEN SAINT MARY NURSERIES}

Deciduous Fruits

\section{Terrell Plum}

\section{PRICES ON TERRELL PLUM.-On Plum stock.}

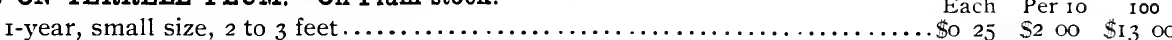

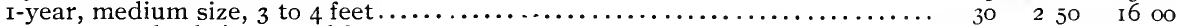

I-year, standard size, 4 to 6 feet.......................... to 3 oo 20 oo

This is probably a seedling of Excelsior. The tree is a strong, healthy grower, very similar in character of growth to Excelsior and also like Excelsior in that it is a heavy annual bearer. The fruit is of large size, $1 / 2$ to 2 inches in diameter; nearly round, slightly ribbed at suture, terminating in blunt point. Color at maturity a beautiful reddish yellow, somewhat mottled, covered with purplish bloom; assumes a wine-red when fully ripe. Flesh greenish yellow, meaty, sweet, toned with sufficient acidity to give a fine flavor, juicy ; quality excellent ; pit very small ; clingstone. We have no hesitancy in recommending the Terrell as one of the finest, if not the finest variety, for all parts of Florida and the Gulfcoast country.

\section{PEARS}

Pear-blight, now present in nearly all parts of the country has proven to be a serious drawback in pear-growing. As a result the market prices have greatly advanced, and when a crop of Pears is secured it is a paying crop.

By careful attention to pruning, fertilizing, cultivation and selection of varieties, Pears can be grown successfully. Varieties of the Oriental group are best adapted to the lower South, and these are the only ones we offer to the trade. Such varieties as Le Conte, Smith and Magnolia are little troubled by blight, while Kieffer is practically immune when properly cared for.

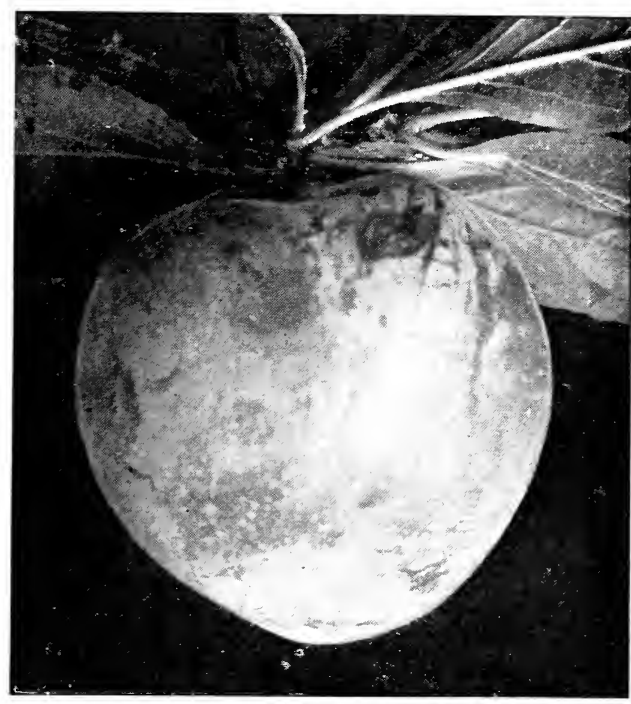

Terrell Plum $\begin{array}{rrrr}\text { Each } & \text { Per ro } & \text { ico } & 1000 \\ \text {.\$O I5 } & \$ 130 & \$ 10 \text { OO } & \$ 7,500\end{array}$ 20 I 50 I 2 OO 9000 $25 \quad 200 \quad 1500 \quad 12000$
Garber. Fruit resembles the Kieffer in size, appearance and quality, but the tree is more open in growth. Comes in ahead of the Kieffer. A seedling of the Chinese Sand Pear.

Kieffer. Fruit large to very large ; color yellow, with bright vermilion cheek, very handsome; flesh very juicy, brittle, a little coarse but of good quality. September and October. The trees should not be allowed to overbear while young, which they are inclined to do ; extremely prolific and very valuable. Supposed cross between the Chinese Sand and the Bartlett.

Le Conte. Larg a to very large, pyriform in shape; skin smooth, pale yellow; when properly handled the quality is good. Early July. The tree is a remarkably vigorous grower, with luxuriant foliage; prolific and an annual bearer. It adapts itself more readily than any other va- riety to radically different conditions of soil and climate. In sections of the South where few other Pears are satisfactory, Le Conte has found its home. Supposed cross of the Chinese Sand with a cultivated variety.

Magnolia. Described by its introducers as large to very large, slightly pyriform, basin narrow and shallow. Color solid glossy reddish brown. Flavor sprightly and good, a commingling of sweet and sour, agreeable and refreshing. Matures later and keeps better than Kieffer.

Smith (Smith's Hybrid). Uniformly large and perfect, smooth and handsome; similar in form and color to the Le Conte, melting and juicy, with smooth, creamy texture; quality good when properly ripened. Ripens with or ahead of Le Conte. An early annual and prolific bearer. Tree equals the Le Conte in luxuriant growth. a 


\section{GLEN SAINT MARY NURSERIES}

\section{JAPAN PERSIMMONS}

Persimmons are easily grown, have few enemies and are prolific bearers. The fruit stands shipment well, is large, strikingly handsome and to most palates very delicious. When properly handled properly marketed, displayed on fruit-stands at just the right stage of ripeness, its exceptional beauty and unusual flavor commend good, in fact, often fancy prices.

Some of the varieties have dark flesh, others light flesh, still others a mixture of the two. The light and the dark flesh differ radically in texture and consistency, as well as appearance, and, when found in the same fruit, are never blended, but always distinct. The dark flesh is never astringent ; the light flesh is astringent until it softens. The dark-fleshed fruit is crisp and meaty like an apple, and is edible before it matures. Some of the entirely dark-fleshed kinds improve as they soften. The light-fleshed kinds, and those with mixed light and dark flesh, are very delicious when they reach the custard-like consistency of full ripeness. In some, the astringency dis. appears as the fruit begins to soften; in others, it persists until the fruit is fully ripe. Seeds accompany the dark flesh. Light-fleshed kinds are seedless. Those with mixed flesh have seeds in proportion to the quantity of dark flesh. The time of ripening, August to December.

\section{PRICES ON PERSIMMONS}

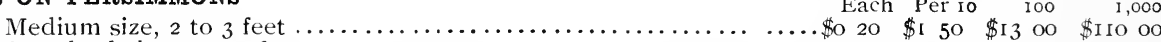



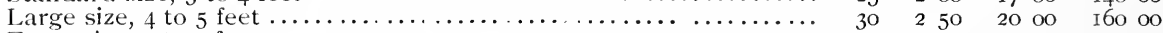

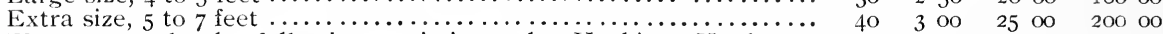

We can supply the following varieties only, Hachiya, Hyakume,

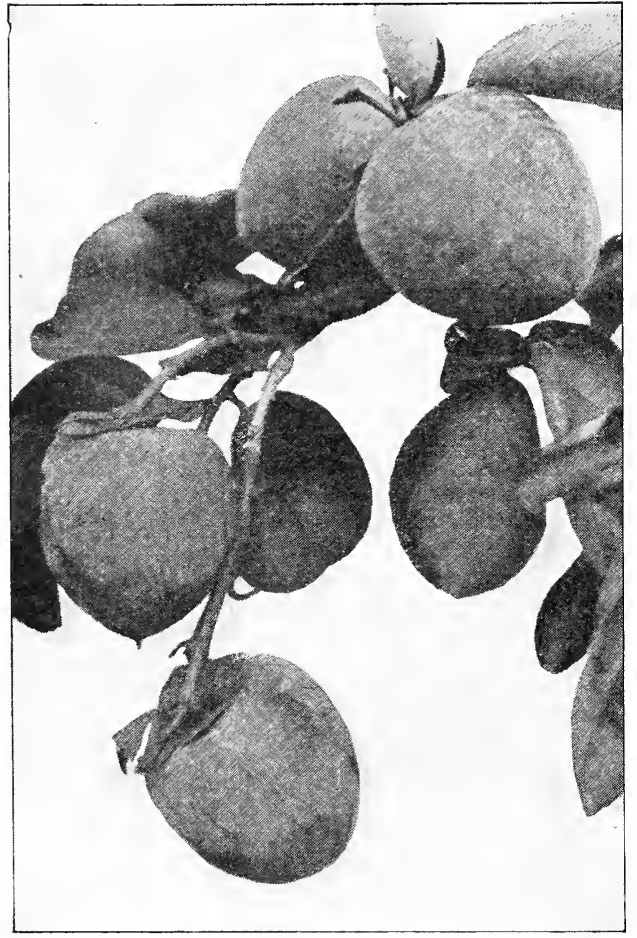

Tane-Nashi Persimmons
Okame, Tane-nashi, Tsuru, Yeddo-ichi, Yemon and Zengi, in well-branched, two-year size, at 50 cts. each, $\$ 4$ for Io, $\$ 35$ per Ioo.

Costata. Medium size, conical, pointed, somewhat four-sided ; diameter $2 \frac{1}{8} 8$ inches longitudinally and $25 / 8$ inches transversely; skin salmon-yellow; flesh light yellow, dark flesh and seeds occurring seldom; astringent until ripe, then very fine; one of the latest to ripen; a good keeper. Tree distinct; a rapid, upright grower; foliage luxuriant.

Hachiya. Very large, oblong, conical, with short point; very showy; diameter $3 \frac{3 / 4}{4}$ inches longitudinally and $3 \frac{1}{2}$ inches transversely; skin dark bright red, with occasional dark spots or blotches and rings at the apex; flesh deep yellow, sometimes having occasional dark streaks, with seed. Astringent until ripe, then very fine. The largest and handsomest of all. Tree vigorous and shapely.

Hyakume. Large to very large, varying from roundish oblong to roundish oblate, but always somewhat flattened at both ends; generally slightly depressed at the point opposite the stem; diameter $23 / 4$ inches longitudinally and $3 \frac{1}{8}$ inches transversely; skin light buffish yellow, nearly always marked with rings and veins at the apex; flesh dark brown, sweet, crisp and meaty, not astringent; good while still hard. The tree is of good growth and a free bearer.

Okame. Large roundish oblate, with welldefined quarter marks, point not depressed; diameter $23 / 8$ inches longitudinally and $3 \frac{1}{8}$ inches traversely; skin orange-yellow, changing to brilliant carmine, with delicate bloom 


\section{GLEN SAINT MARY NURSERIES}

Deciduous Fruits

and waxy, translucent appearance; light clear flesh when ripe, with light brown center around the seeds, of which it has several ; loses its astringency as soon as it begins to ripen; quality fine. Tree vigorous and a good bearer.

Taber's No. 23. Medium, oblate, flat or depressed point; $1 \mathrm{I} / 8$ inches by $23 / 8$ inches; skin rather dark red, with peculiar stipple marks; flesh dark brown, sweet and free from astringency; seedy; good. Prolific.

Taber's No. 129. Medium roundish, flattened at base; has a small but well-defined point at the apex; diameter about $2 \frac{1}{2}$ inches both ways; skin dark yellow-red, with peculiar roughened surface, somewhat resembling alligator leather; flesh light brown, crisp, sweet, free from astringency ; excellent ; a good keeper and shipper. Vigorous, prolific, regular bearer.

Tane-Nashi. Large to very large, roundish, conical, pointed, very smooth and symmetrical ; diameter $3^{1 / 4}$ inches longitudinally and $33 / 8$ inches transversely; skin light yellow, changing to bright red at full maturity; flesh yellow and seedless; quality very fine; perhaps the most highly esteemed of the light-fleshed kinds. Tree is vigorous and bears well. One of the most desirable market varieties.

Triumph. Medium, tomato-shaped; skin red; flesh yellow; generally has a few seeds; very productive; quality of the best. Ripens from September until November. See back cover page for illustration showing actual color.
Tsuru. Large, slender, pointed; longest in proportion to its size of all; diameter $3 \frac{3}{8}$ inches longitudinally and $23 / 8$ inches transversely ; skin bright red; flesh orange-yellow, some dark flesh around the very few seeds; astringent until fully ripe, then the quality is good. The latest of all to ripen. Tree vigorous; good bearer.

Yeddo-Ichi. Large, oblate; diameter $21 / 2$ inches longitudinally and 3 inches transversely ; very smooth and regular in outline, with dinted appearing surface and slight depression at $\epsilon$ nd opposite the stem; skin darker red than most varieties, with heavy bloom; flesh very dark brown verging toward purplish; sweet, rich, crisp; in quality one of the best. Edible when still hard. Tree very prolific and thrifty.

Yemon. Large, flat, tomato-shaped, somewhat four-sided; diameter $21 / 4$ inches longitudinally and $3^{1 / 4}$ inches transversely; skin light yellow, changing to a dull red, mottled with orange-yellow; distinct in color; flesh deep, dull red, brown around the seeds, of which there are usually a few. Some specimens are entirely light fleshed and seedless ; quality fine. In form some of the fruits have the corrugations converging to the depressed apex, but most do not. Tree vigorous and prolific.

Zengi. The smallest of all ; round or roundish oblate; diameter $\mathrm{r} 3 / 4$ inches longitudinally and $2 \frac{1}{4}$ inches transversely; skin yellow ish red; flesh very dark, quality good; seedy ; edible when still hard; one of the earliest to ripen. Vigorous and exceedingly prolific.

\section{FIGS}

No fruit is more valuable in the southern fruit garden than the Fig. They can be closely planted, Io to I 2 feet apart, and yield heavily. The Fig-canning industry is gradually extending throughout the South, and since several tons of fruit can be produced on an acre of ground, it is well adapted to intensive culture. The preserved product put up at the present time in no wise supplies the demand, and we look for a very material increase in the Fig-canning industry.

The fresh Fig is also finding its way into the markets, and meeting with a ready sale. Carefully picked at the right stage of maturity and packed in strawberry crates, they can be placed by express in distant markets, four or five hundred miles, or even more, in good condition.

Figs come into bearing very early and for that reason commend themselves to the fruit-grower.

PRICES ON FIGS



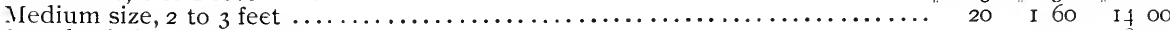

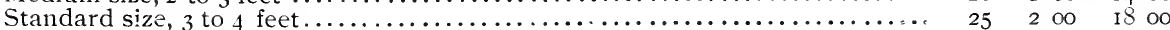

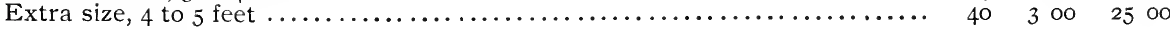

Blue Genoa. Medium to large size; skin bluish black; quality good. Tree a strong grower and good bearer.

Brunswick. Fruit very large, broadly pearshaped, with short, rather slender stalk; ribs well marked, eye large, open, with rosy scales ;

skin tough, dark brown in color; pulp thick, soft, quality very good and a satisfactory variety.

Black Ischia. Size medium to large; color of skin bluish black, almost entirely covered with delicate bluish bloom; quality good; strong grower, heavy bearer and quite hardy. 


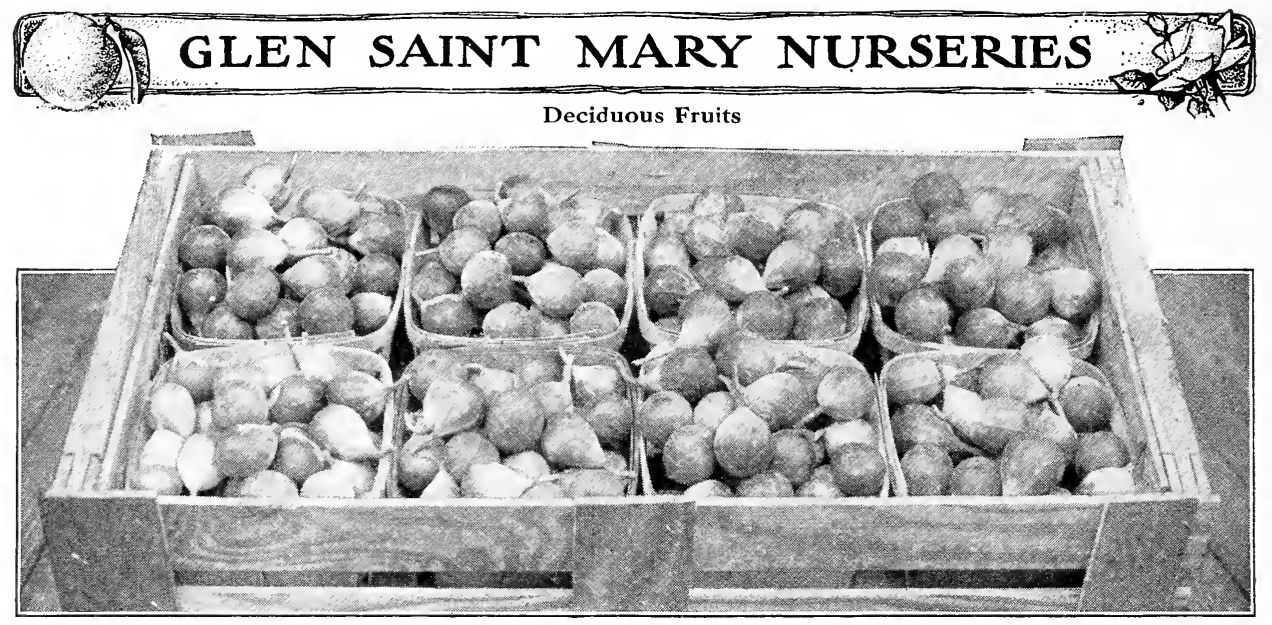

Celestial Figs ready for shipment

Celestial. Small to medium pear-shaped, ribbed, violet colored, sometimes shading to purplish brown, covered with bloom about half way up from the neck; stem short, stout. Flesh whitish, shading to rose-colored at center; flesh firm, juicy, sweet, excellent quality. One of the hardiest varieties of Figs, and $c+n$ be grown far outside of the usual limits of culture ; very desirable for canning and preserving.

Green Ischia. Fruit of medium size, long, pulp rosy red, soft melting, quality rich, sweet, a variety of very high quality. A strong grower and should be in every Fig collection.

Lemon. Fruit medium to large, flattened, faintly ribbed, color light yellowish green, stem short, stout; flesh white, sweet, quality fair to good, flesh rather soft; ripens during July. Strong grower and very prolific.
Magnolia. Fruit of large size, light-colored, handsome, vigorous grower, prolific, excellent for canning; a favorite with Texas planters.

Brown Turkey. Size medium to large, broadly pear-shaped, with short thick stalk; ribs few in number; color coppery brown, flesh white, or slightly amber colored, shading to pink about the seeds. Flesh solid, excellent quality. This variety ranks with Celestial in hardiness. It is very hardy and in every way desirable.

White Adriatic. Size medium to large, flattened, slightly turban-shaped, ribs not well marked, eye open, skin thick, color greenish yellow, or light yellow; flesh rosy red, a good grower, and gives excellent satisfaction on rich strong land.

\section{POMEGRANATES}

The Pomegranates are very hardy shrubs which can be grown throughout the Gulf states and the coastal sections of Georgia and the Carolinas. The brilliant scarlet flowers are produced in profusion, and the Pomegranates are generally very prolific, and thrive with little care. The fruit is used in making jellies, marmalades and acid drinks. For this latter purpose they are highly esteemed. The fruit has a fresh crispness, delicacy and sprightliness of flavor found in few fruits. The Pomegranate is one of the coming commercial fruits, and the interest in its culture is gradually increasing.

PRICES ON POMEGRANATES.-On own roots. Each Per io roo

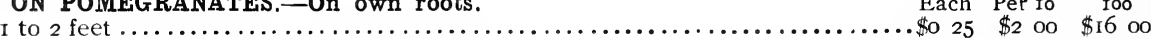

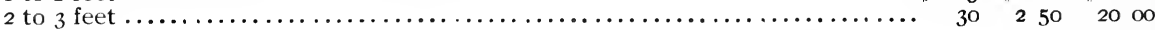

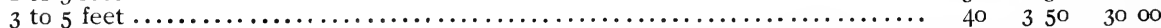

Purple-seeded. Large; rind thin ; juicecells surrounding the seeds (the edible portion of the fruit) dark ruby or wine-color; sprightly, vinous, and of the best quality.

Rhoda. This variety was brought to our attention by one of our employes, on whose place it has been growing for some years. We have named it in honor of his wife. The fruit is of large size; rind thin but tough ; juice-cells large and of beautiful wine-color; crisp, sweet and of exquisite flavor. One of the best we have ever seen. 


\section{GLEN SAINT .MARY NURSERIES}

Deciduous Fruits

\section{MULBERRIES}

While Mulberries are of little value for commercial purposes or table use, there are nevertheless several purposes for which they are admirably suited and of decided value. They form an economic food for poultry and swine, and for tolling birds away from other fruits there is nothing else so effective.

PRICES ON MULBERRIES.-On Mulberry Stock.

Each Per so 100

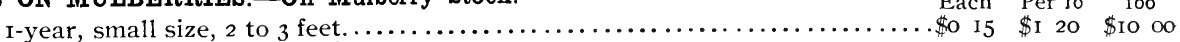

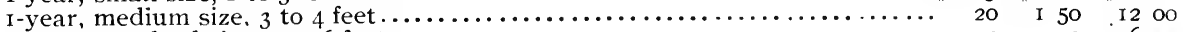

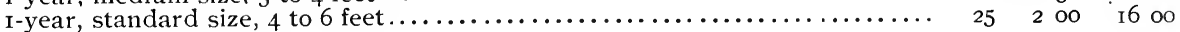

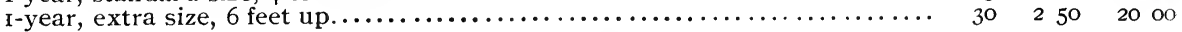

Downing. A subacid berry of good quality; strong, upright grower, with beautiful foliage; valuable as a shade tree, as well as for its fruit.

Hicks. Fruit sweet; tree grows rapidly and bears young; productive; should be grown by every farmer who keeps swine or poultry, this variety being of special value for this purpose ; continues in bearing four months of the year.

Stubbs. Large, black; vinous; excellent ; very prolifice. The fruit, which is from $\mathrm{I}^{1 / 2}$ to 2 inches long, is greatly superior to that produced by any of the cultivated varieties; very acid. Tree vigorous and handsome.

Townsend. A new variety, which on account of its extreme earliness we have deemed worthy of propagation. Berries of medium size and fair quality. Brought to our attention by one of our employees of that name, on whose place it had been growing for years. Should be planted where birds are apt to ruin other early fruits. March and April.
Multicaulis (Morus multicaulis). The Silkworm Tree. A very vigorous tree, extensively used for purposes of propagation, for shade and for feeding silkworms.

White. A white-fruited form, vigorous and prolific. Should be generally planted.

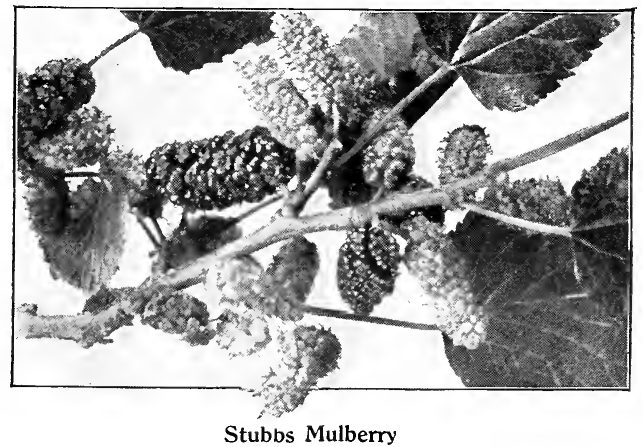

\section{APPLES}

While the Gulf region is not recommended for extensive Apple orchards for commercial purposes, yet in localities, particularly in its upper edge, some varieties are successfully grown. Our list embraces those which succeed best further south.

\section{PRICES ON APPLES}

I-year, medium size

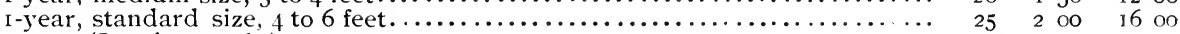

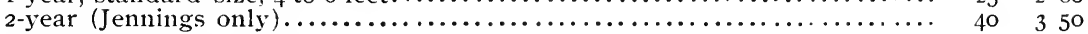

Ben Davis. Medium to large; roundish, truncated; conical; yellowish, overspread, striped and splashed with two shades of red; subacid, of fair quality. A late ripener and good keeper. Widely planted; popular.

Early Harvest. Medium to large; yellow, juicy, tender, of fine flavor. A well-known and popular variety. Ripens in June.

Horse. Large, rather oval in shape, ribbed, yellow in color; flesh yellow and subacid. Highly esteemed throughout the southern Ap- ple districts as a summer Apple. Excellent for drying and cooking.

Jennings. The Jennings or "Jennings' Florida" Apple succeeds farther south than any other variety, and is unquestionably the variety to plant, as it grows well and yields fair crops of good Apples in sections below the range of this fruit. And throughout the Gulf country westward, including coastwise Texas, where Apples are planted, and the selection is limited to one variety, the Jennings will prove 
most satisfactory. It has been grown in this (Baker) county many years under the name by which we offer it.

Red Astrachan. Large ; crimson, with heavy bloom; flesh crisp, acid and juicy. Ripens in June. The tree is vigorous and bears very young. Is perhaps adapted to a wider range of climate than any other variety.

Red June. Medium conical ; deep red ; juicy; very productive. A beautiful and thrifty tree. One of the best for the lower South, ripening from June 20 to July i 5 .

\section{GUAVAS}

The Guava is a sub-tropical fruit, and quite hardy; in fact, it can be cultivated throughout practically the same range as the hardy varieties of oranges. The leaves are bright green and shiny, while the fruit is highly esteemed for making jellies and preserves. Among the Guavas, the Cattley (Psidium Cattleyanum), is the hardiest species. Of this we offer two varieties.



Red Cattley Guavas
PRICES ON GUAVAS.-From seed Each Per to I to 2 feet............... 35 \$3 oo 2 to 3 feet................. 40.6 o 35

3 to 4 feet................. 5o 450

Red Cattley. A handsome evergreen shrub, with glossy green leaves, producing large quantities of small, red fruits, $I$ to $I / / 4$ inch in diameter. It can be grown in northern Florida, the Gulf-coast country and more tropical regions.

Yellow. Identical with the Red Cattley, except that the fruit is yellow instead of being redHeshed. Both of these varieties are very desirable.

\section{QUINCES}

While the Quince does not succeed all over the whole lower South, yet it does well in many localities and should be planted. It naturally prefers a rather moist, loamy soil. We offer two of the best and most noteworthy varieties.

PRICES ON QUINCES.-On Quince stock.

Each Per Io

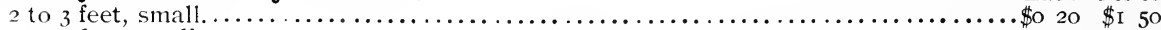

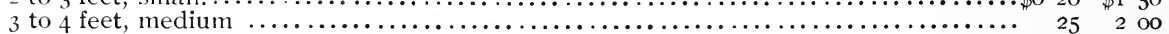

Orange. Large; golden yellow, with firm flesh and excellent flavor. A strong grower and thrifty variety.
Pineapple. One of Luther Burbank's introductions. Of large size, smooth and rounded. Fine for jelly and cooks tender.

\section{LOQUAT}

\section{Eriobotrya Japonica, Japanese Medlar, Biwa of the Japanese}

The Loquat is a strikingly handsome, large-leaved evergreen tree adapted to the Gulf-coast country and more tropical locations. The leaves are large, dark green and rough; the young shoots woolly. A compact grower, and forms a well-rounded head. It is very desirable as an ornamental.

Nor is it desirable as an ornamental only, for its fruit, which is about the size of a Wild Goose plum, oblong, bright yellow, subacid, has an agreeable flavor and is highly prized for cooking; makes a most excellent jelly.

The white blossoms, borne in spikes, come during the winter months; consequently, while trees are quite hardy all along the Gulf coast, fruit can be counted on only in sections comparatively exempt from severe cold. 


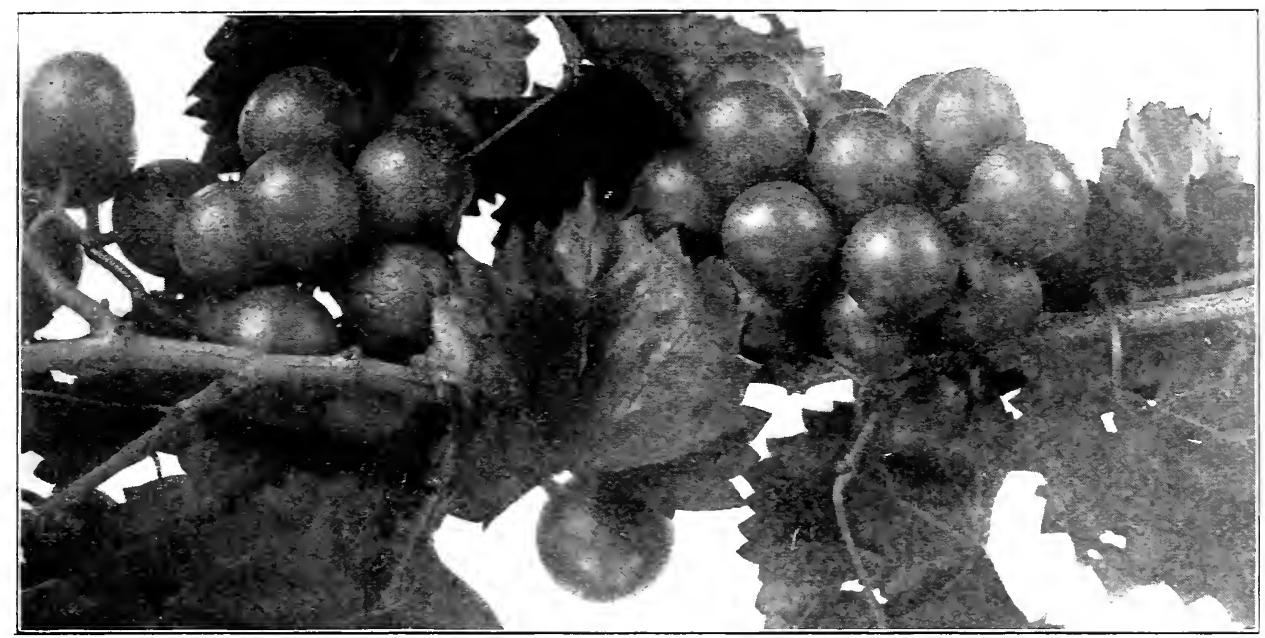

Scuppernong Grapes

\section{GRAPES}

Grapes of the Muscadine group are native in the southern states and, of all the Grapes which may be grown, they are the best adapted to southern conditions. Generally the clusters are quite small as compared with the bunch Grapes, but the fruit has a fine flavor and is valuable as a table Grape, for making unfermented grape juice, for jellies and for wine. In Virginia and North Carolina the culture of Muscadine Grapes for wine-making is rapidly becoming an important industry.

Many persons who have planted the Scuppernong Grape have found that their vines, when they reach sufficient size, bloom but set no fruit. We guarantee all our Scuppernong vines to bear fruit as soon as they are well established and have reached sufficient size. If ther do not, we will either replace them or refund the money paid for them.

Quite a number of bunch Grapes are also well adapted to the South. In a number of sections they are grown for market, and there are few localities where a sufficient quantity cannot be raised for home use. We particularly recommend Delaware, Diamond, Ires, Moore's Early and Niagara.

\section{PRICES ON MUSCADINE GRAPES}

\section{Muscadine}

Eden. A seedling of the Scuppernong, originated in Georgia. Medium-sized black berries, somewhat acid. A good wine Grape; bears early ; very productive.

Flowers. Bunches composed of fifteen to twenty large purplish black berries; sweet, vinous. Good quality. One of the best known and most largely planted varieties of the Muscadine type. August and September.

James. Very valuable, the largest of the Muscadine group; berries often measuring 3/4 to $\mathrm{I} / \mathrm{I}$ inches in diameter; prolific ; black, juicy, sweet. Has taken premiums wherever exhibited. Ripens from August until late in the fall.

Mish. The vine is very vigorous and prolific. Berries black, medium to large; sweet. Ripens in August.
Scuppernong. Belongs to the Muscadine type. Bunches composed of eight or ten very large berries, bronze-colored when fully ripe; flesh pulpy; sweet, with peculiar agreeable musky flavor; quality excellent. Aug. and Sept.

Thomas. Belongs to the Muscadine type, and one of the best of its class. Bunches seldom exceed eight or ten berries; color reddish purple; pulp sweet, tender. Aug. and Sept.



\section{Bunch Grapes}

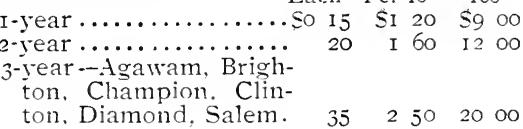




\section{GLEN SAINT MARY NURSERIES}

\section{Roses}

Agawam. A strong-growing variety with large bunches of large, dark reddish brown grapes. The fruit is of good quality and flavor.

Brighton. Bunches medium; berries large and reddish; skin thin; a desirable table variety.

Champion. Bunches and berries medium, round, blue-black; vine healthy and vigorous. Very early. Too tender for long shipment.

Glinton. Bunches of medium size; berries round, black, pulpy and juicy. Fruit keeps well. A good grower.

Concord. Bunches and berries very large, blue-black, with bloom; flesh sweet, pulpy, tender, good; vine vigorous. Heavy bearer; desirable for home markets. July.

Delaware. Bunches small to medium; berries small, skin red or pink, and very thin; sweet, juicy, vinous; quality best. One of the best in the South. July.

Diamond. A handsome white Grape equal or superior to Niagara in quality, and ten days earlier. Prolific, very thrifty and vigorous. Well suited for culture in the South, both for home use and market.

Ives. Strong grower; very productive; stands shipping well; bunch large; berries large, black, pulpy, sweet, of good quality. A popular wine Grape. Quality much better in the South than in the North. June.

Moore's Early. Similar to Concord in size and shape, but better and earlier.

Niagara. Bunch and berry large; greenish yellow; flesh sweet; quality good. Vigorous and prolific. One of the best for Florida.

Salem (Rogers' No. 53). Bunch large, com pact; berry very large, round, coppery red; flesh tender, juicy; quality best. Ripens with Concord. Vigorous, productive.

Wilder (Rogers' No. 4). Bunch large, compact, shouldered; berry large, round, black ; flesh tender, juicy, sweet. Ripens about with Concord. Vine vigorous, hardy, good bearer.

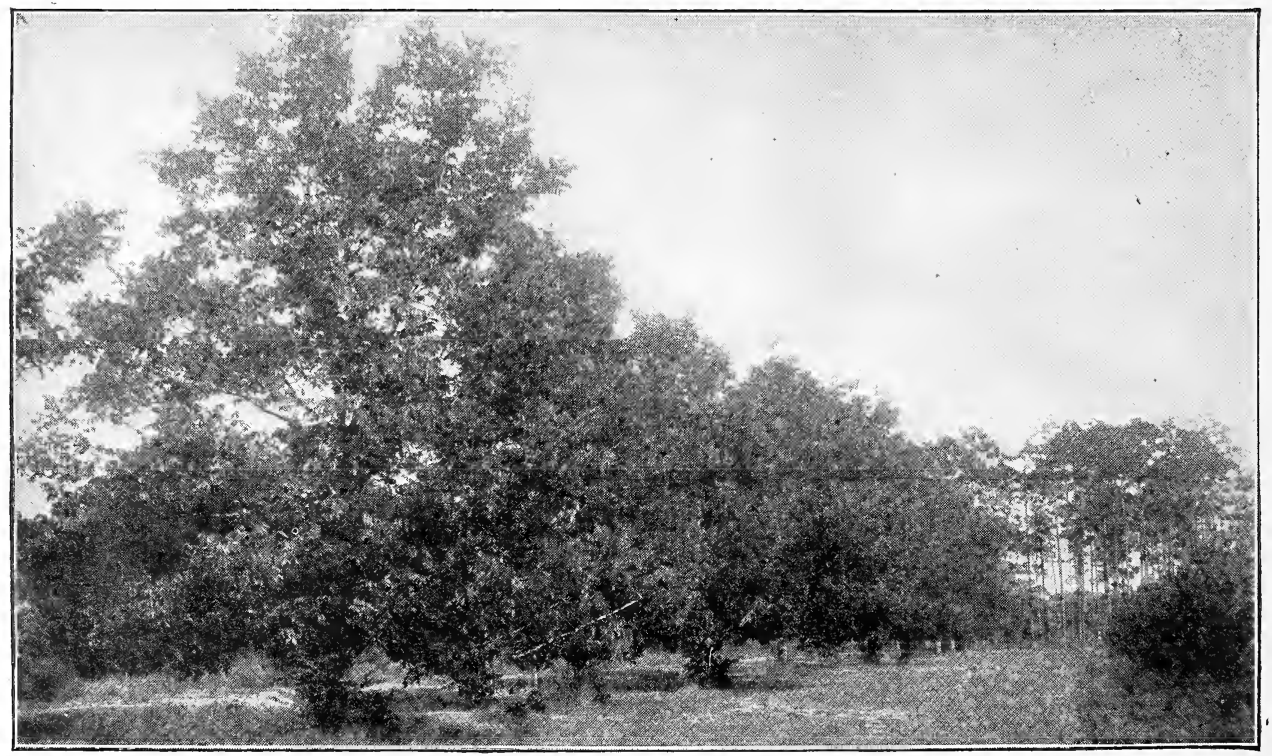

Old Frotscher Pecan Trees

\section{PECANS}

Throughout the southern states no fruit or nut tree is better adapted for general planting or more worthy of careful cultivation than the Pecan. It is to the South what the apple is to the North-worthy of a place in every fruit-garden, on every lawn, and the most important fruit tree from the standpoint of the orchardist. The Pecan fits well into the general farming of the regions 


\section{GLEN SAINT MARY NURSERIES}

\section{Deciduous Fruits}

to which it is adapted. It must be planted farther apart than other fruit trees, leaving ample space for the cultivation of general farm crops. These crops may be grown advantageously, with benefit to the trees, and will more than cover the cost of maintenance, until they commence to bear.

Double plantings of Pecans, figs, peaches, pomegranates, plums, oranges and other smaller-growing trees may be made to good advantage. These come into bearing early and soon pay the cost of the whole planting.

As an avenue and shade tree, the Pecan is without a superior. It is a stately tree, longlived and a rapid grower when cared for.

We emphasize the facts that our trees are true to name and well grown. They are thrifty, vigorous and will give satisfaction.

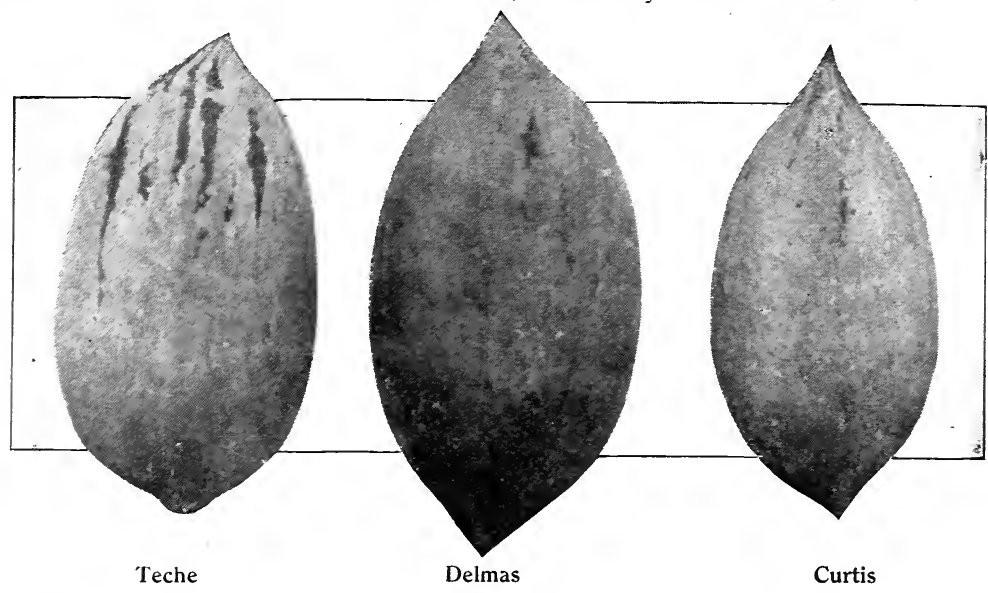

PRICES ON BUDDED PECANS

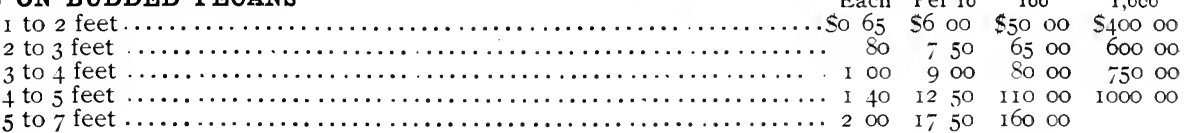

Curtis. A medium-size Pecan, ovate, with bright, clean shell, marked with a few purplish specks; rounded at the base, pointed at the apex; shell very thin ; cracking quality excellent; kernel light yellow, plump and full ; rich, sweet, nutty flavor. Quality best. A desirable nut for home use or market; a regular bearer.

Delmas. Size large, ovate; dark gray in color, marked with dark specks and streaks; shell medium thick; cracking quality good; kernel bright yellow; flavor sweet; quality good. This variety is noted for coming into bearing very early, in fact, the earliest bearer with which we are acquainted.

Frotscher. A large, oblong nut, $13 / 4$ or $17 / 8$ inches in length; bright yellowish brown in color with a few purplish black markings; shell very thin, cracking easily. Kernel large, easily removed, full, of good quality. One of the handsomest nuts grown. Tree a vigorous grower, of spreading habit with scaly bark, bears heavy crops. IVe have been propagating this variety for years from bearing trees grafted by ourselves with scionscut from the original tree in Louisiana.

Russell. A medium- or large-sized nut, $\mathrm{I} 1 / 2$ to $\mathrm{I} 3 / 4$ inches long, oval and pointed, grayish brown with numerous, small purplish black markings. Shell very thin, of excellent cracking quality ; kernel plump and of good quality. This variety is a good grower with small, clean, characteristic foliage. Bears well and is a very satisfactory variety.

Schley. Size medium to large, $\mathrm{I} / 2$ to $\mathrm{I} 7 / 8$ inches long; oblong, somewhat flattened; light reddish brown with a few small markings of purplish brown; shell thin, separating easily from the kernel; kernel full, plump, bright yellowish brown in color; flavor rich, nutty, in quality one of the best. Tree a good grower and on the whole a very excellent variety.

Stuart. Nuts large or very large, $\mathrm{I} 3 / 4$ to 2 inches, long, oblong with brownish shell strongly marked with dark color. Shell of medium thickness and of very good cracking quality. Kernel full, plump, bright colored. In quality one of the best, the flavor being rich and sweet. A heavy bearer. Tree a strong grower, reaching an immense size, with large foliage.

Teche. Size medium to large, oblong; grayish brown in color, with a few dark streaks; base and apex rounded; shell medium thick ; cracking quality very good; kernel full, plump; sutures broad and rather deep; quality good. A seedling of Frotscher. 




Frotscher

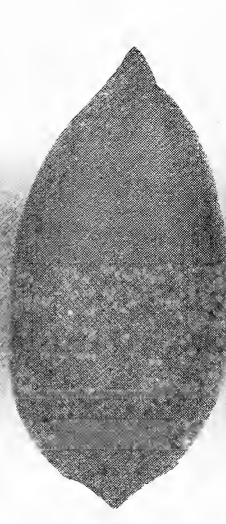

Schley

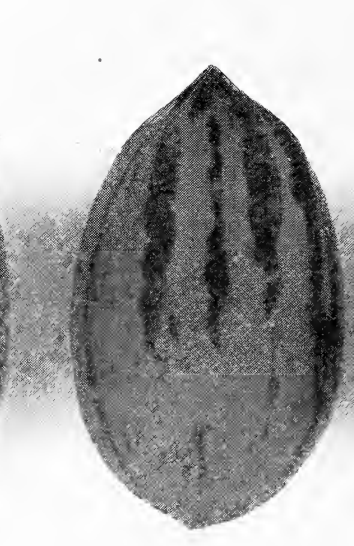

Stuart

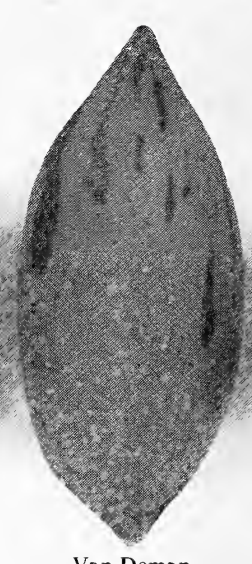

Van Deman

Van Deman. Large to very large, from $7 / 8$ to $2 \frac{1}{8}$ inches long, rather slender, pointed at both ends. Color reddish brown with purplish brown markings. Shell of medium thickness; cracking quality excellent. Kernel full, and plump, bright brownish yellow; flavor sweet and good. Tree a strong, vigorous grower.

\section{The Pecan and Its Culture}

\section{By H. HAROLD HUME}

To supply reliable information on Pecan-growing, this work, touching every cultural detail, has been prepared after a number of years' careful study of the industry. The book is practical and contains the information needed by every Pecan grower. Price 75 cts., postpaid.

\section{SEEDLING PECANS}

We have seedling trees grown from large, selected nuts from our own bearing trees. These are much more apt to produce fine nuts than seedlings from a mixed lot of inferior nuts. While we do not recommend seedlings, it is better to plant them than not to plant Pecans at all.

PRICES ON PECANS-Seedlings, from thin-shelled selected nuts

I to 2 feet

2 to 3 feet

$\begin{array}{crrrr}\text { Each } & \text { Per ro } & \text { I0o } \\ 20 & \$ 1 & 60 & \$ 13 & 00 \\ 30 & 2 & 50 & 20 & 00\end{array}$



\section{JAPAN WALNUT}

In the development of the nut industry, the Japan Walnut is well worthy of a place in every planting, and no home orchard should be without a few trees. They should be planted on welldrained land, - a sandy or clay loam with a clay foundation is well adapted. The tree is a vigorous grower and comes into bearing early. In habit of growth they are low and spreading, reaching a height of 15 or 20 feet, with a spread of branch of about the some distance. The leaves are large and handsome. The nuts are borne in clusters of fifteen to twenty. They have rather thick shells, with sweet, plump kernels of very fine quality. They make beautiful lawn or shade trees.

FRICES ON JAPAN WALNUTS FROM SEED

Each Io

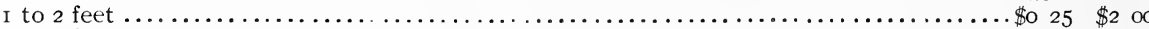

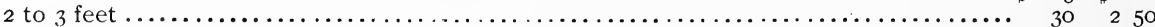



\section{ALMONDS}

PRICES ON ALMONDS-Sultana on Peach stock

Each Per io 100

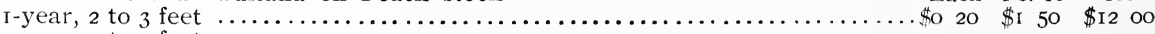

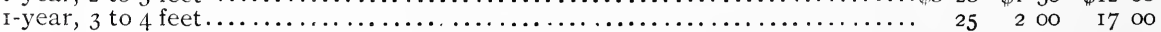

Not certain bearers in the South and are not recommended except for garden planting. 


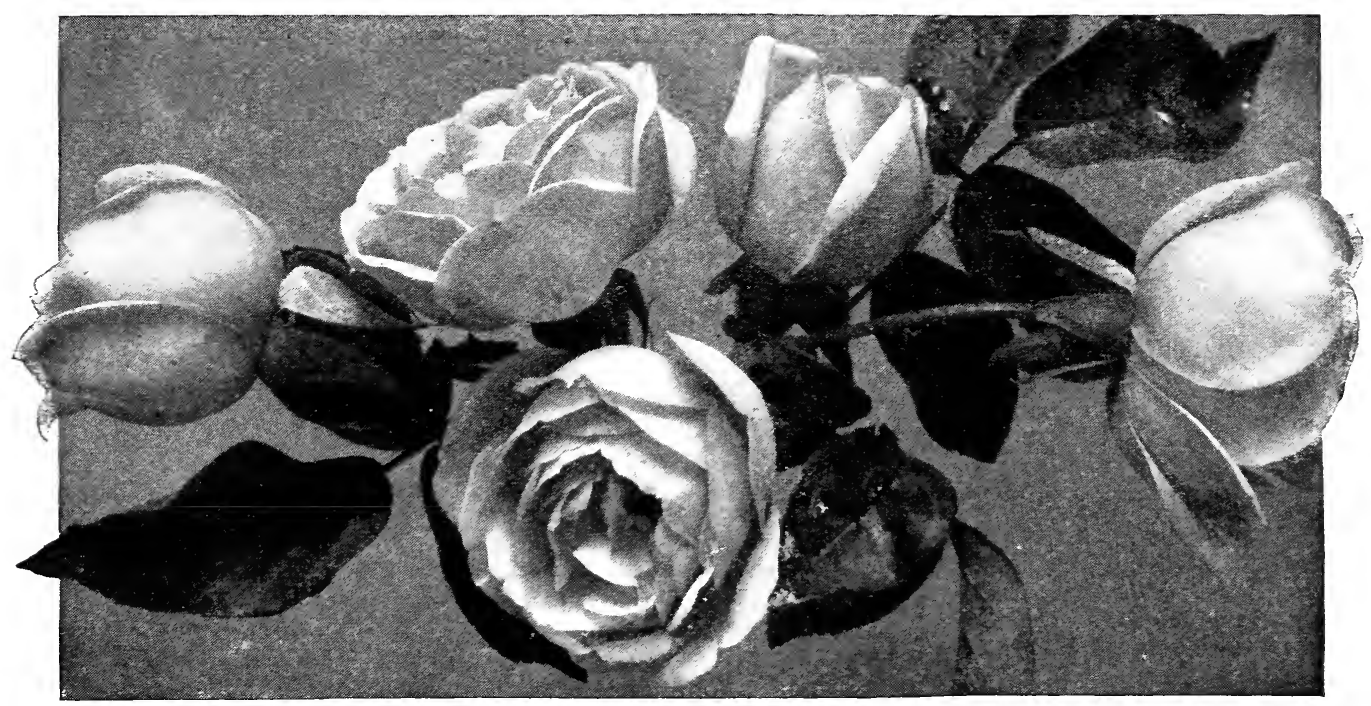

Duchesse de Brabant Roses (See page 32,

\section{ROSES}

Roses are the most important flowering shrubs of the South. Nowhere in the country do they develop in such beauty or bloom in such profusion. No garden is complete without its rose bed, no planting scheme is perfect which does not provide a place for them.

With few exceptions, the most satisfactory results will be secured by planting Roses grafted on strong growing roots. Nearly all Roses grown from cuttings are vastly inferior, producing poor, weak plants as compared with grafted specimens. Our Roses are strong, grafted plants, grown in the open field, - the kind of Roses that gire satisfaction. In planting, the graft union should be placed two or three inches under the surface of the ground.

CLIMBING ROSES are usually regarded as valuable only for porches or trellises. While useful for these purposes they are often much more satisfactory as bush Roses. Climbing Roses are strong growers ; given plenty of room and severely pruned, they produce an abundance of bloom never surpassed and not often equaled by the true bush Roses. The ability of a Rose to bloom depends on its ability to grow and produce new wood.

Roses are derived from a number of different classes. These classes are indicated by initial letters in parentheses immediately following the name of the variety. The key to these classes is as follow's :

Bk., Banksia; Beng., Bengal ; Bour., Bourbon; C. B.. Climbing Bengal ; C. C., Climbing China; C. N., Climbing Noisette; C. T., Climbing Tea; H. C., Hybrid China ; H. N., Hybrid Noisette; H. P., Hybrid Perpetual ; H. T., Hybrid Tea ; Mult., Multiflora; N., Noisette ; Pol., Polyantha ; P., Prairie; T., Tea ; II'., Wichuraiana.

This season we have roughly divided our list according to color to make selections easier.

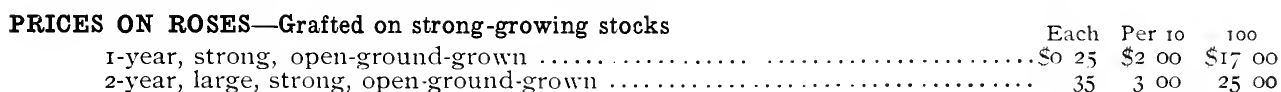

\section{RED ROSES}

Agrippina. (Beng.) Crimson. Profuse bloomer, strong grower, fine for bedding.

Alfred Colomb. (H. P.) A beautiful shade of clear red, large double flowers. Very fragrant.
Bessie Johnson. (H. P.) Red. Silvery on outside of petals. Flowers medium size. Vigorous.

Charles Lefebvre. (H. P.) Red shading to crimson. A very free bloomer and one of the most satisfactory of its class for this section. 


\section{GLEN SAINT MARY NURSERIES}

Roses

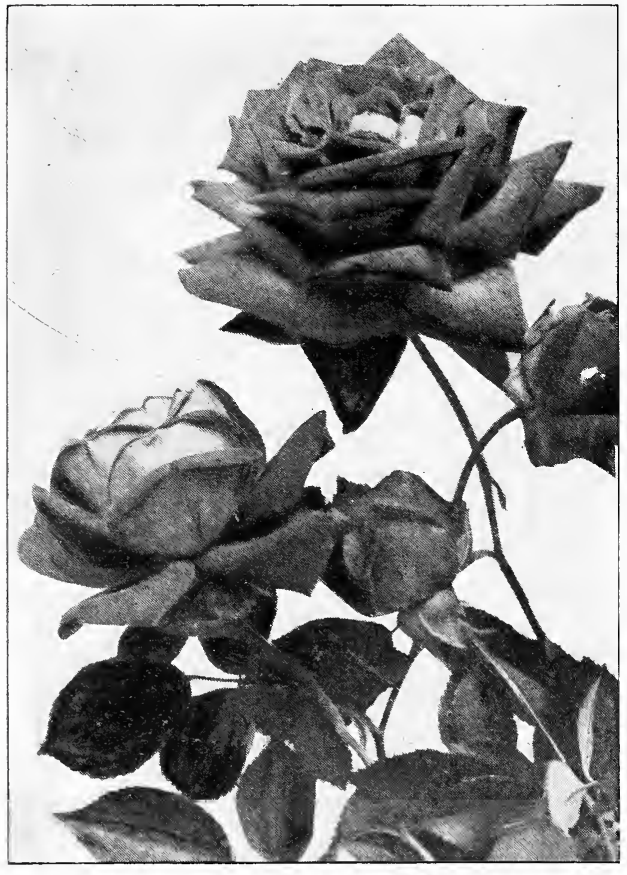

James Sprunt

Gheshunt Hybrid. (H. T.) Red with reverse of petals silvery pink changing to maroon as they become older. Flowers very double. Good buds. Very strong grower. One of the best.

Climbing Wootton. (H. T.) Very large, rather open flowers, beautifully formed; color bright magenta-red, passing to crimson, richly shaded. A free bloomer, strong grower and a beautiful rose. It gives excellent satisfaction both in growth and flowers.

Grimson Rambler. (Pol.) Bright crimson flowers produced in clusters of 30 to 40 , each flower being $I$ to $1 \mathrm{I} / 2$ inches in diameter. A very strong-growing climber.

Douglass. (Beng.) Deep maroon, dark and velvety. Free-flowering.

General Jacqueminot. (H. P.) Crimson, well formed and not surpassed in beauty and brilliancy of color. Strong grower and free bloomer for its class.

Giant of Battles. (H. P.) Crimson. Flowers of medium or large size, double and fragrant.
Gracilis. (C. B.) Flowers bright rosy red, large and full. A climber suitable for planting in both sunny and shady locations.

James Sprunt. (C. B.) Deep cherry red flowers, very full, double and sweet. The cut flowers keep for a remarkably long time in perfect condition. It is a moderate climber, makes a good pillar Rose, and the exceptionally brilliant and beautiful flowers are to be found at all seasons.

Louis Philippe. (Beng.) Rich velvety crimson. While not so valuable for bouquets as some varieties, it is the most showy and satisfactory dark Red Rose we have for gardens and grounds. It makes a large, vigorous bush, and there is scarcely a time during the entire year when it is not covered with bright red flowers.

Madam Barriglione. (T.) Bright carmine, tinted with salmon, semi-double flowers, fine buds, very vigorous.

Madam Sadie Carnot. (T.) Cherry red; a very good variety.

Marshall P. Wilder. (H. P.) Flowers very large, perfectly double, and of good substance; color bright cherry red, shading to crimson. Plant a clean healthy grower.

Mrs. Cleveland. (H. P.) Dark red or crimson, velvety, well formed, medium to large, very fragrant. A good grower.

Papa Gontier. (T.) Outer petals red, inner ones pink. A free-flowering Rose of great merit, with beautifully formed buds and flowers. Very vigorous and one of the best Roses in our collection.

President Lincoln. (H. P.) Crimson, dark and velvety. Strong grower with good foliage, and medium to large flowers.

Pride of Reigate. (H. P.) Crimson, handsomely striped with white, sometimes half crimson and half white.

Prince Albert. (H. P.) Beautiful bright crimson; very large, full and fine.

Princess Bonnie. (T.) Crimson with inner surface of petals lighter, dark margin. Flowers large, loose and open. Fine bloomer, always in flower, vigorous. Lasts well as a cut flower.

Queen's Scarlet. (Beng.) Rich crimson, changing to lighter scarlet. A very distinct and striking shade. Very free blooming.

Reine Marie Henriette. (C. T.) Cherry red, a pure shade, which does not fade or shade off into undesirable tints; large, double and beautifully formed; somewhat fragrant. This is one of the finest red climbing Roses in our collection, and we strongly recommend it. 


\section{GLEN SAINT MARY NURSERIES}

Roses

Rev. J. B. M. Camm. (H. P.) Bright red, shading to crimson, full, of good form. Blooms well.

Ulrich Brunner. (H. P.) Clear bright crimson. Flowers large, globular. Bush a strong grower, desirable.

Victory. (H. P.) The flowers are of immense size and splendid substance; beautifully formed, very full, round and double. Color deep rich velvety crimson. A grand Rose.

Virginia R. Coxe (Gruss an Teplitz). (H. T.) A bright, dazzling, crimson, with beautiful buds and medium double flowers of large size. A profuse bloomer throughout the whole season. A strong and vigorous grower and should be given plenty of space.

\section{PINK ROSES}

Alphonse Soupert. (H. P.) Bright clear pink, very handsome and showy. A satisfactory sort.

Anne de Diesbach. (H. P.) A bright clear pink, with large petals, delicately veined. Flowers large and very double. It is a vigorous grower and produces its beautiful flowers in abundance. Sweet scented. A fine variety.

Antoine Mouton. (H. P.) A vigorous grower, bearing flowers of extraordinary size. Bright, clear pink, reverse of petals silvery rose.

Apolline. (Bour.) Light pink, shaded darker on edges, vigorous, free bloomer, flowering in clusters.

Archduchess Marie Immaculae.

(T.) Pink, yellow at base of petals. Flowers large and beautifully formed. A strong growing variety and very desirable.

Archduke Charles. (Beng.) Brilliant crimson-scarlet, often marked with lighter shades. This is a good grower and very satisfactory variety.

Baby Rambler. (Pol.) A dwarf Rose, reaching a height of 18 to 20 inches; flowers pink, double, produced in dense clusters of two to three dozen. It is always in flower, even in the hot weather of mid-summer, and makes a beautiful mass of bloom. A very desirable Rose.

Bon Silene. (T.) Deep salmon-rose, marked with carmine ; highly scented. Valuable for its buds, which are large and of fine form and color. Very strong and robust in this section; bears profusely the year round. An old favorite.

Bougere. (T.) Light pink, outer surface of petals darker, buds of medium length, free bloomer, strong grower.
Captain Christy. (H. T.) Extra large, flat flowers, very full and regular; the color is a lovely shade of light pink, deeper toward the center. Vigorous, a free bloomer; one of the best in our grounds.

Catherine Mermet. (T.) Pink with the inner surface of the petals lighter colored, good bloomer, well-formed buds, medium vigorous. A good variety.

Champion of the World. (B. C.) Clear light pink, globular buds of medium size. Good grower.

Clement Messier. (C. N.) Medium size; full and double; white petals surrounding delicate pink center; very pretty in either bud or flower; sweet tea scent; a strong grower.

Climbing Bridesmaid. (C. T.) Somewhat similar to its parent, Bridesmaid; dark pink, variable in color. Strong climber and a splendid variety.

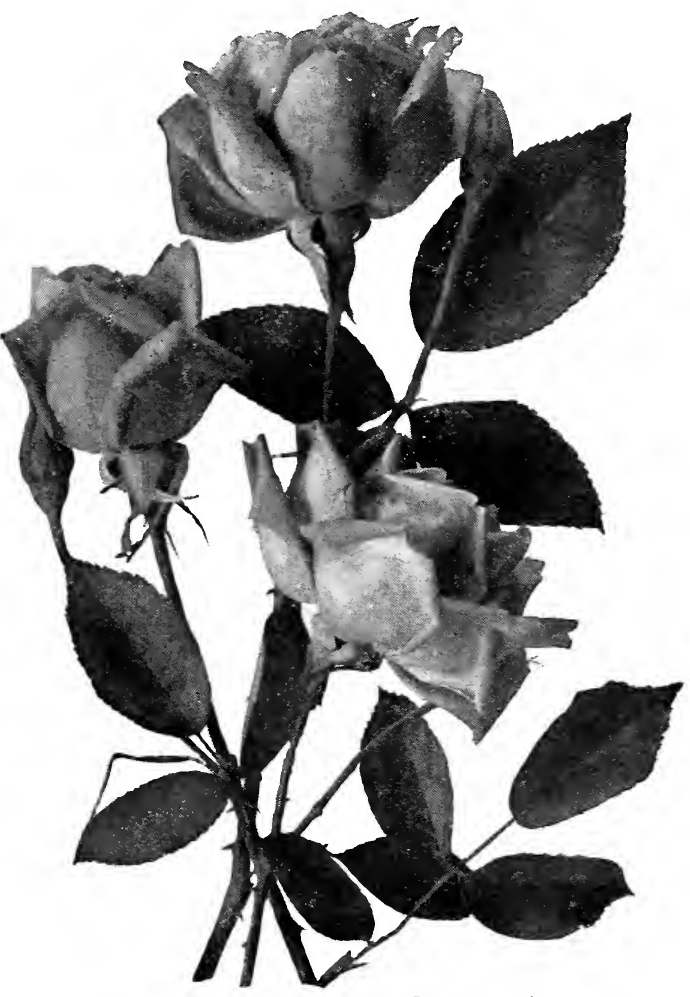

Reine Marie Henriette (See page 30) 


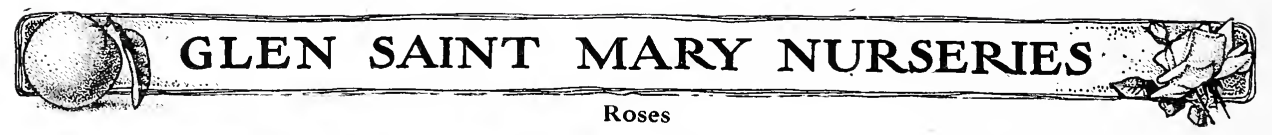

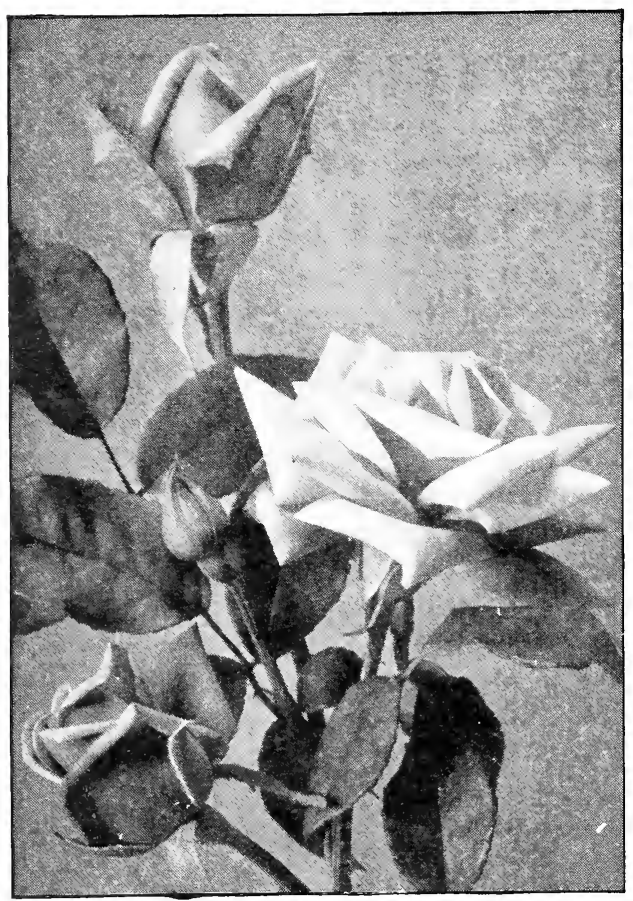

Màdam Lambard (see page 33)

Comtesse Eva Starhemberg. (T.) Pink with salmon tint. Outer surface of petals darker. Yellow at the base, fine buds, flowers opening flat. Strong grower.

Comtesse Riza du Parc. (T.) Pink, deeper on edges, inner surface of petals lighter than outer, a strong grower, free bloomer. A very desirable sort.

Coquette Bordelais, (H. P.) Pink, large regular flowers, vigorous grower.

Duchesse de Brabant. (T.) Pink, petals deeper colored on outer surface. Buds and flowers globular. Very free bloomer, vigorous and excellent for planting in beds, as the bushes when in bloom are very showy. An old-fashioned garden Rose of great merit.

Duke of Edinburgh. (H. P.) Dark pink, velvety, inner surface of petals lighter. Flowers medium size, vigorous. Very handsome and fragrant.

Ellen Drew. (H. P.) Clear pink, flowers medium size, double.
Empress of China. (C. C.) Pink climber ; flowers loose and open; semi-double; vigorous. A very strong grower, with handsome Howers. Very hardy and blooms early.

Francois Levet. (H. P.) Deep pink or light red. Flowers of large size, double and handsome. Vigorous.

Heinrich Schultheis. (H. P.) Clear pink, flowers very full and double, of good size. A vigorous grower.

Henry M. Stanley. (T.) Pale pink, edged and mottled deep rose, with a lovely shade of salmon on reverse of petals. Large, double and full.

Her Majesty. (H. P.) Beautiful shade of pink ; large, well-formed flowers, sweet scented; very double. A vigorous grower, producing flowers on long stems.

Hermosa. (Bour.) Clear light pink flowers produced in clusters. A free-blooming vigorous sort.

Improved Rainbow. (T.) Pink, petals striped with deeper pink, beautifully marked; full globular buds. An odd and very desirable variety. Sport from Papa Gontier.

John Hopper. (H. P.) Dark bright pink, lighter on onter surface of petals; large and full. A stout, strong grower. Bears a succession of flowers extending through the season, and is one of the best of the Hybrid Perpetuals in this region.

Jules Finger. (T.) Dark pink, almost red; good buds; flowers good size; very double. A desirable Rose.

Jules Jurgensen. (C. B.) Old rose-pink, darker in center, very regular petals. Strong grower; a good climber.

La Grandeur. (T.) Light pink with dark pink veins; inner petals twisted smaller and shorter than outer ones. Flowers in clusters of five to 15 . Good grower.

La Reine. (H. P.) Dark pink, petals lighter on the outer surface; large-flowered, double and fragrant. Quite vigorous.

Louis Richard. (T.) Pink with salmon shading, petals darker on the outer surface; wellformed buds on long stems. Good grower and bloomer.

Mad. De Vatry. (T.) Pink, outer petals and outer surfaces red or deep pink; vigorous; good bloomer, with large handsome foliage.

Mad. Gabriel Luizet. (H. P.) Pure ligh t pink; regularly formed; large flowers. A good bloomer. 


\section{GLEN SAINT MARY NURSERIES}

\section{Roses}

Mad. Joseph Desbois. (H. P.) Light delicate pink; very large flowers beautifully shaded. Vigorous.

Mad. Lambard. (T.) Pink, darker on outer petals, outer surfaces of petals shaded deeper pink; very vigorous; good bloomer. A satisfactory and desirable variety. We recommend it highly.

Mad. Philemon Cochet. (T.) Light pink; a free bloomer. Very vigorous and desirable.

Mad. Scipion Cochet. (T.) Pink, edges of petals darker ; flowers globular ; free blooming ; strong grower with handsome bright foliage. Very satisfactory.

Magna Charta. (H. C.) Bright clear pink ; very full and double; very vigorous, making a large bush.

Marie Ducher. (T.) Light pink, outer surface of petals darker; buds dark pink. Strong grower; very desirable.

Marie Zahn. (H. T.) Pink, large, lighter on outer petals; vigorous and a good bloomer, with strong stems.

Mrs. George Paul. (Bour.) Light pink ; good; regular; double flowers. Vigorous; distinct.

Paul Neyron. (H. P.) Strong and vigorous; pink ; full ; double. The largest-flowered Rose grown, often measuring 6 inches across. A very desirable variety, and one of the best Hybrid Perpetuals for the South.

Princess Louise Victoria. (H. P.) Salmonpink; medium size. A splendid climbing Rose.

Santa Rosa. (T.) Pink, with dark pink buds; dwarf, vigorous, very free blooming; medium-sized flowers. An excellent Rose ; excellent for bedding.

Souvenir d'un Ami. (T.) Light pink, outer surface of petals darker; buds long and pointed. Vigorous; free bloomer.

Souvenir de Leonie Viennat. (C. T.) Best pink climber; base of petals yellow, margins pink, general color pink. Very thrifty; free bloomer.

Souvenir de Madam Pernet. (T ) Light pink, edges of petals deep pink ; full globular buds; good grower and bloomer. Same character as Duchesse de Brabant, but darker in color.

Vick's Caprice. (H. P.) Pink, fairly dark, petals often striped with lighter color.

York and Lancaster. (H. P.) Pink or white. One of the oldest Roses in existence, dating back to the time of the Wars of the Roses. Very thrifty grower.

\section{WHITE ROSES}

Blanche de Muer. (H. P.) White, tinted with pink, small or medium flowers, double. Vigorous.

Bride. (T.) White, slightly pink tinted on outer petals, buds long pointed, outer petals spreading, a very free-blooming variety and a great favorite.

Climbing Glothilde Soupert. (C. T.) White, globular buds, pink tinted in the center, flowers in clusters of three to eight, free-blooming, a strong growing climber.

Climbing Marie Guillot. (C. T.) White. Very double; strong grower. Flowers in clusters of two to five. Foliage large and bright; a desirable variety.

Climbing White Pet. (Mult.) Strong-growing Rose of the Rambler class; showy white flowers borne in clusters; fragrance like cherry blossoms.

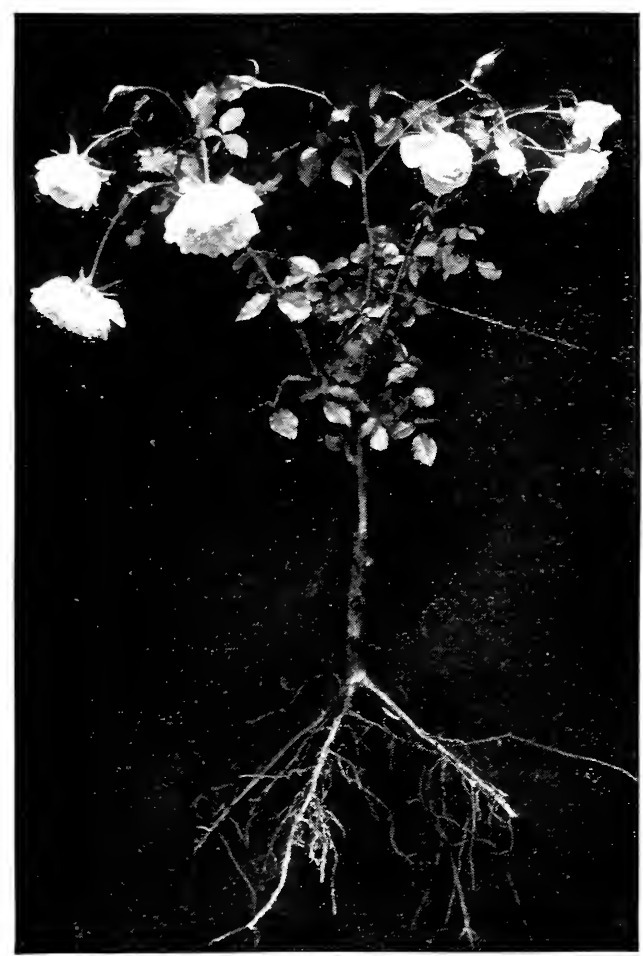

Queen Rose, four months after grafting (See page 35) 


\section{GLEN SAINT MARY NURSERIES}

\section{Roses}



lsabelia Sprunt Rose (See paye 35)

Coquette des Alpes. (H. N.) White, tinted pink or very light pink; flowers medium size, vigorous grower.

Coquette des Blanches. (H. N.) White or slightly pink tinted. Globular buds, flowers small to medium.

Devoniensis. (C. T.) White tinted with pink; with beautiful buds. This is one of the most desirable climbing sorts and is not surpassed by any other variety in vigor of growth. it blooms profusely and flowers are always to be found.

Empress Marie of Russia. (T.) White, tinted with yellow and pink, good buds and large flowers. We believe this Rose to be one of the best of its class.

Estelle Pradel. (C. N.) Lovely, pure white buds ; flowers medium size, full and sweet; profuse bloomer. A favorite climbing Rose in the South.

Elise Boelle. (H. N.) White, delicately tinged with pink; medium size, full, beautiful, circular form ; very sweet. A lovely Rose.

Kaiserin Augusta Victoria. (H. T.) White with lemon center. Full pointed buds. Vigorous and a good bloomer. Very double. This Rose is one of the newer sorts, with handsome bright foliage. The flowers are borne on long straight stems. A variety of great merit.

Madam Alfred Carriere. (H. N.) White, pink tinted. Flowers rather loose, medium size. A strong grower and free bloomer. It grows well with us.

Madam Jean Sisley. (Beng.) White ; edges of petals crimped. Outer petals pink. Vigorous.

Margaret Dickson. (H. P.) White, faintly tinted with pink. Petals very large and flowers almost as large as those of Paul Neyron. The foliage is large and handsome.

Marie Guillot. (T.) White, tinted with yellow and light pink. A vigorous Rose with large, full, double flowers.

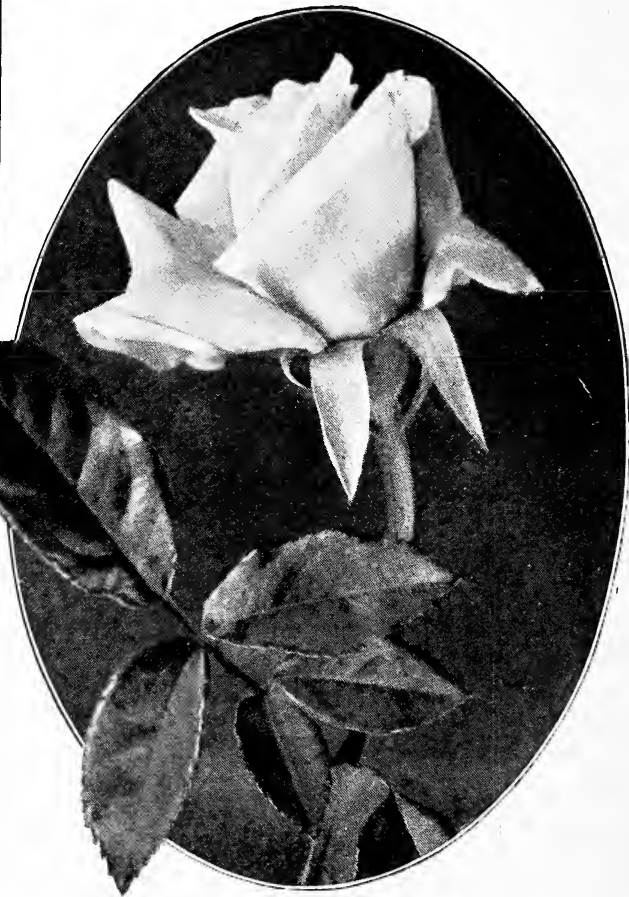

White Maman Cochet (See page 35) 


\section{GLEN SAINT MARY NURSERIES}

\section{Roses}

Marie Lambert. (T.) White. Beautifully formed buds. Sweet scented, vigorous. A free bloomer and one of the best for early spring flowers.

Marie Van Houtte. (T.) White with lemon tint, pink on outer petals. Buds of good size. Flowers turning pink as they fade. Good bloomer, thrifty grower, leaves large and shining. A very handsome and desirable Rose.

Merveille de Lyon. (H. P.) White, tinted with pink, large well formed flowers. Vigorous.

Perfection des Blanches. (H. N.) White, vely slightly tinted. Medium-sized flowers. Regular and very double. Vigorous.

Pearl Rivers. (T.) White, outer petals tinted pink; fine buds and good double flowers. A vigorous Rose.

Queen. (T.) Pure white, with globular buds, and good double flowers produced in clusters of three to fifteen, one of our best white Roses. Very free-flowering and vigorous.

Sylphide. (T.) White, slight pink tint. Inner petals irregular; flowers medium size. Free bloomer, strong grower. A good garden variety.

White Maman Cochet. (T.) Pure white, or white with very slight, delicate, pink tint on the outer petals ; full, double, beautiful pointed buds, with regular shell-like petals. A profuse bloomer and strong, vigorous grower. We can strongly recommend it as one of our best Roses.

White Perle des Jardins. (T.) White, lemon tinted in center. Open flowers have petals turned back along edges giving them a pointed appearance. Strong grower and one of the most distinct and desirable white Roses.

\section{YELLOW AND SALMON ROSES}

American Banner. (T.) Salmon-pink, petals pink tinted on outer edges; of good size; buds pointed. Strong grower and good bloomer

Chromatella. (C. N.) Lemon-yellow; longpointed buds; very vigorous and free-blooming. An old and desirable sort.

Etoile de Lyon. (T.) Yellow; large full flowers; deep yellow with good buds and large double flowers. It blooms profusely and is a strong grower. Desirable yellow bush Rose.

Ferdinand Batel. (H. T.) Salmon on inner surface and pink on outer surface of flowers; good buds and flowers; vigorous and desirable. A very handsome Rose.

Fortune's Double Yellow. (C. T.) In color this Rose is a striking blending of yellow, sal- mon and bronze of beautiful shades. A strong, vigorous grower, producing its half-double flowers in spring in great profusion.

Gloire Lyonnaise. (H. P.) Light salmonyellow, sometimes creamy white, A large-flowered variety and very desirable. A fine Rose.

Isabella Sprunt. (T.) Lemon-yellow; buds like Safrano. Fine bloomer a very desirable variety. Vigorous.

Letty Coles. (T.) Salmon-yellow ; largeflowered ; flowers, in shape, resembling Madam Lambard. Very vigorous grower and a good variety.

Mad. Caroline Kuster. (N.) Yellow, salmon center; well-formed buds; flowering in clusters. A desirable climbing Rose.

Marechal Niel. (C. N.) Deep yellow; very large; full globular form; delightfully fragrant. The finest of all yellow Roses. In the South it is at home. A strong, vigorous grower, producing freely its magnificent flowers at all

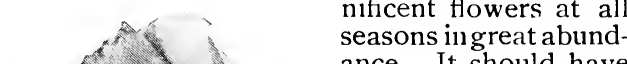
seasons ingreat abund-
ance. It should have - 2 the first place in every

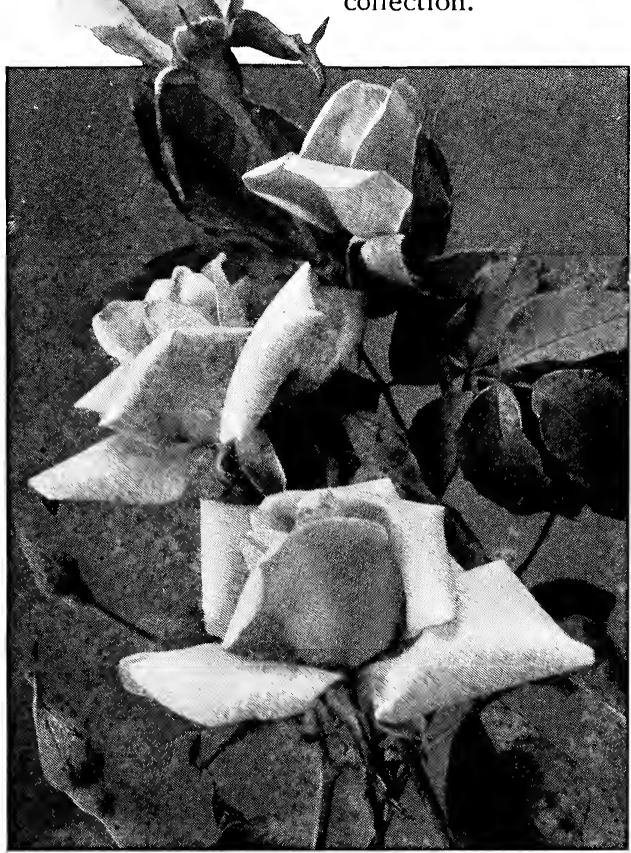

Safrano Rose (see page 36 ) 


\section{GLEN SAINT MARY NURSERIES}

Shade Trees



Etoile de Lyon Rose (see page 35)
Media. (T.) Yellow; large full buds; deep yellow in center, lighter on the outer surfaces ; free bloomer; strong grower. An excellent yellow bush Rose.

Reve d'Or. (C. T.) A very free-flowering climbing Rose, with salmon-colored buds. It closely resembles Safrano, but the flowers are more double. It is as good as a climber as Safrano is as a bush Rose.

Safrano. (T.) A delicate and beautiful tint of salmon, which is always bright and clear, and does not fade or shade off into dull and undesirable tints. One of the most exquisitely colored of Roses, and exceedingly beautiful in the bud. In this latitude it makes a vigorous, strong bush, and bears an abundance of flowers at all seasons. One of the best.

Solfaterre. (C. T.) Clear sulphur-yellow; large and double. Foliage and character of growth very similar to Marechal Niel. A splendid climber and profuse and constant bloomer; the flowers do not blight, wilt or fade in the hot midsummer sun like many of the other fine varieties. With proper pruning it makes a splendid bush Rose.

Yellow Soupert. (T. P.) Very similar in character of growth and shape and size of flowers to Clothilde Soupert. The color of the flower is white with delicate chrome-yellow at center.

Rosa viridiflora. (China.) Commonly known as the Green Rose. A strong-growing variety, with green flowers composed of leaf-like petals ; blooms medium size, strongly scented, produced in clusters. Valuable as an oddity.

\section{Shade Trees}

Nowhere in the country is shade so acceptable or so necessary as in the South. Whether in park or city street, country road or lawn, shade trees are valued not as luxuries, but as necessities for health and comfort. Nothing adds more to the home grounds, nothing so improves the appearance of town or city as well-placed healthy, vigorous shade trees.

The list of trees which is offered to our customers we can strongly recommend for planting throughout the southern states. They are well grown, with straight stems and well developed root systems. Grown in nursery rows for a number of years, they are vastly superior to the trees which may be obtained from the woods.

CAMPHOR (Cinnamomum Camphora). An evergreen tree, of handsome, compact growth, with bright, clean foliage. A strong grower on moist, well-drained lands; hardy throughout Florida and the greater portion of the Gulf states. Strongly recommended for windbreaks. Now being planted in Florida on a commercial scale for the production of camphor gum.

\begin{tabular}{|c|c|c|c|}
\hline & $\mathrm{ach}$ & Per ro & IOO \\
\hline to 2 & 20 & $\$$ I 50 & $\$ 1200$ \\
\hline eet, stoc & 25 & 200 & I8 oo \\
\hline 3 to 4 feet, stocky .... & 40 & 3 or & 2500 \\
\hline
\end{tabular}

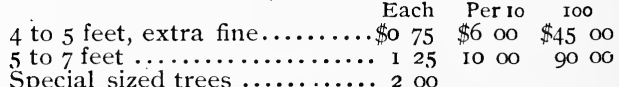

Special sized trees $\ldots \ldots \ldots \ldots \ldots \ldots 2$ oo 
GATALPA speciosa. A hardy deciduous tree of very rapid growth, with large, dark green leaves. The flowers are large, $2 \frac{1}{2}$ inches in diameter, white, with yellow and purple spots, borne in medium-sized clusters. Valuable as an ornamental tree and for its timber. The wood is exceedingly durable and well adapted for cross-ties and fence-posts.

Each Per ro

3 to 4 feet $\ldots \ldots \ldots \ldots \ldots \ldots \ldots \ldots$. 25 \$2 oo

4 to 6 feet.................. 30 2 50

6 to 8 feet $\ldots \ldots \ldots \ldots \ldots \ldots \ldots \ldots \ldots$ 50 4 oo

8 to ro feet ............... I oo $75^{\circ}$

CHERRY LAUREL (Prunus Caroliniana). A small, evergreen tree reaching a height of from 20 to 30 feet, with dark, glossy, green foliage. The flowers are white, small, borne in racemes in spring. They are followed by black cherry-like fruits which mature in autumn and hang on the trees throughout the winter. Grows well throughout the South as far north as Washington. Excellent for specimens or hedges. Each Per ro roo

2 to 3 feet $\ldots \ldots \ldots \ldots \ldots \ldots$ \$o 25 \$2 oo $\$ 18$ oo

3 to 4 feet $\ldots \ldots \ldots \ldots \ldots \ldots$ 40 $300 \quad 2500$

4 to 5 feet $\therefore \ldots \ldots \ldots \ldots \ldots \ldots$. $75 \quad 6$ oo 45 oo

5 to 7 feet $\cdots \cdots \cdots \cdots \cdots \cdots$ I 25 Io oo

Special size.......... 2 oo

ELMS. A group of large, stately, rapid growing trees, well suited for planting on moist soil. They are among our most satisfactory shade trees for streets or lawns. We offer varieties well adapted to the South.

\begin{tabular}{|c|c|c|c|}
\hline 2 to 3 feet... & & $\begin{array}{c}\text { Per } 10 \\
\$ 250\end{array}$ & $\begin{array}{c}100 \\
\$ 2000\end{array}$ \\
\hline to 4 feet............... & 35 & 3 oo & 250 \\
\hline 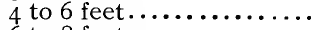 & 40 & 350 & $30 \mathrm{c}$ \\
\hline to 8 feet............... & 50 & $45^{\circ}$ & \\
\hline Io feet $\ldots \ldots \ldots \ldots$ & 75 & 700 & \\
\hline
\end{tabular}

American (Ulmus Americana). A very desirable variety, with long, gracefully curved branches. Leaves green, light beneath, becoming yellow in fall.

Cork (Ulmus racemosa). One of the Elms best adapted to the South, reaching a height of upwards of roo feet, with oblong rounded top. Branches provided with corky wings, and clothed with dark green leaves. A valuable shade tree.

DOGWOOD, White (Cornus Florida). A small tree with spreading bushy top and bright green leaves. The flowers with their large, white bracts, appearing in spring, before the leaves, make the Dogwood one of the most striking ornamental trees. The fruit ripens in autumn and is bright scarlet in color.

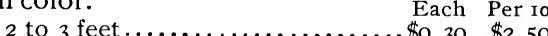

3 to 4 feet $\ldots \ldots \ldots \ldots \ldots \ldots \ldots \ldots \ldots$ 40 $\quad \begin{aligned} & 32 \\ & 50\end{aligned}$

4 to 6 feet.................. 50 450
Pink Dogwood. A handsome variety of Cornus Florida, with bright pink flowers. Equally hardy with the white form and can be grown wherever it can. Budded. 3 to 4 feet \$I each, \$9 per io.

FLOWERING WILLOW (Chilopsis linearis). A spreading tree, reaching a height of I 5 or 20 feet. Leaves long, narrow, willow-like. Flowers lilac striped with yellow, borne throughout most of the summer. Will grow and do well on dry land. Very handsome and odd.

Each Per to

I to 2 feet................\$o $25 \$ 2$ oo

2 to 3 feet.................. 30 30 250

3 to 4 feet..................... $40 \quad 350$

4 to 6 feet $\ldots \ldots \ldots \ldots \ldots \ldots \ldots \ldots$. 50

HACKBERRY (Celtis occidentalis). A large, rapid-growing tree, with spreading branches and rounded head. Leaves oblong, narrow, pointed. A very satisfactory shade and avenue tree, and grows well over a wide area.

2 to 3 feet................

3 to 4 feet................... 35 oo

4 to 6 feet................. 50 5 450

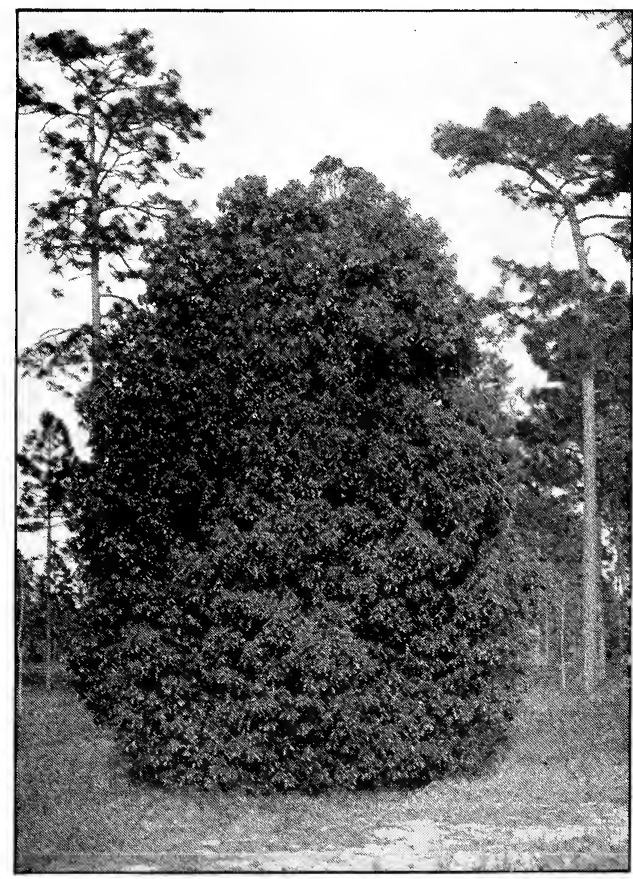

Camphor Tree (See page $\left.{ }^{6} 6\right)$ 


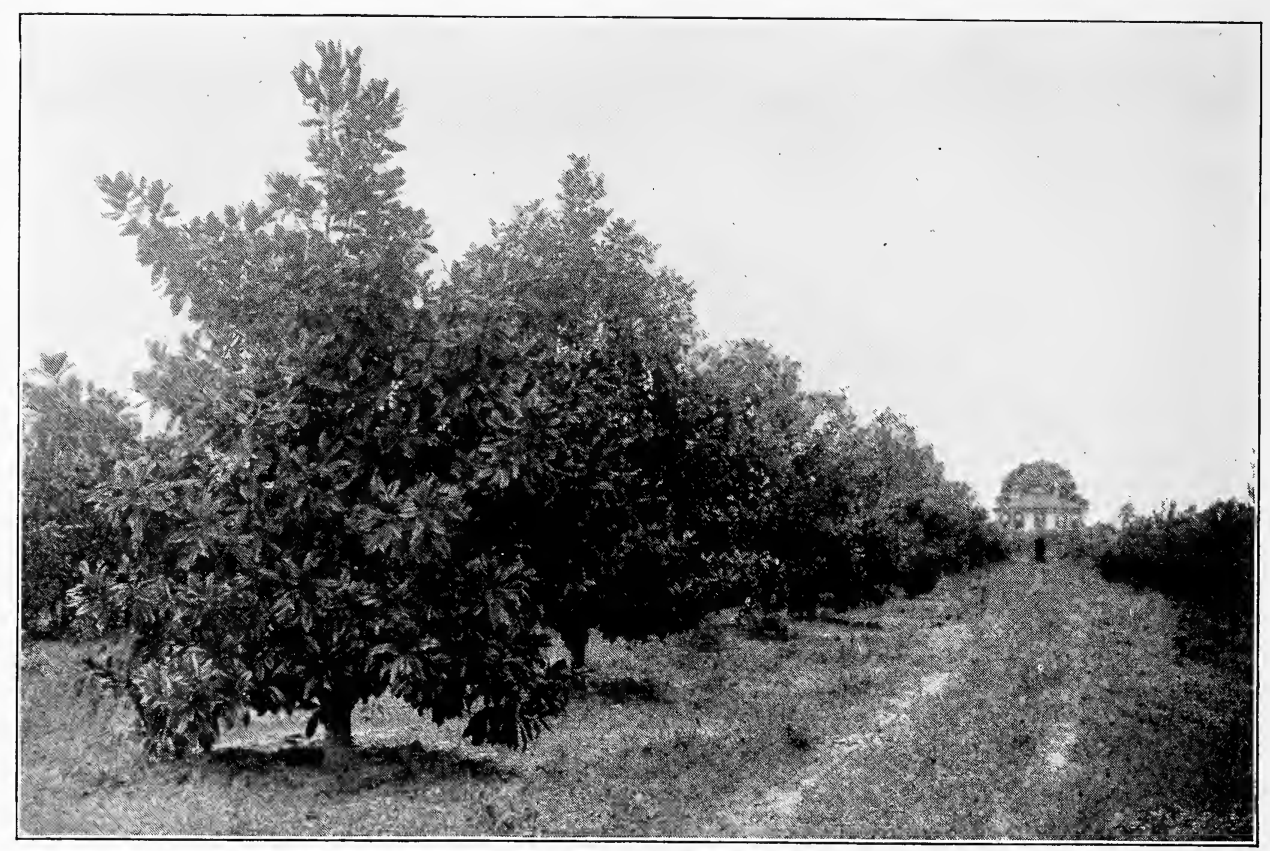

Magnolia grandiflora, as an Avenue Tree

HOLLY (Ilex opaca). Well known as the Christmas Holly. This tree, with bright, green, spiny leaves and brilliant scarlet berries, is one of our handsomest evergreen shade trees. A moderately rapid grower and succeeds on a wide range of soils. Should be severely cut back when transplanted.

Each Per io

I to 2 feet.................. \$o 40 \$3 50

2 to 3 feet.................... 5 , 450

3 to 4 feet.................... $75 \quad 6$ oo

4 to 5 feet................ I oo 9 оо

5 to 7 feet.................. I 20 10 00

JAPANESE VARNISH TREE (Sterculia platanifolia). A rapid-growing, smooth, greenbarked deciduous tree, with large leaves; head round and medium sized. An excellent shade and ornamental tree.

Each Per io I to 2 feet................. \$o 40 \$3 50

2 to 3 feet................. $45 \ldots \ldots$

3 to 4 feet................ $75 \quad 650$

MAGNOLIA grandiflora. The grandest, broadleaved evergreen of the southern forests. Leaves large, bright shining above, usually coated with brownish hairs beneath. Flowers beautiful, large, often 8 or ro inches across, waxy white, lemon-scented and produced throughout a period of two or three months. Our trees are nursery-grown and well-rooted.
Prices of Magnolia grandiflora. Each Per to too I to 2 feet............... 40 o $\$ 350 \quad \$ 30$ oo 2 to 3 feet.............. 50 450 ( 50 on 3 to 4 feet.............. $75 \quad 650$ 4 to 6 feet............. I oo 9 oo 8 o oo 6 to 8 feet.............. I 25 Io oo 90 oo

MAPLES (Acer) are among our most valuable shade and ornamental trees. They grow rapidly and are long lived, while their colors, changing with the seasons from early spring to late autumn, lend a pleasing touch to the landscape.

Prices on Scarlet and Silver Maples. Each Per Io

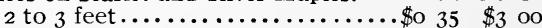
3 to 4 feet...................... 50 \% 4 oo 4 to 6 feet...................... $75 \quad 650$ 6 to 8 feet.................... I 25 го оо 8 to ro feet................... 2 oo 15 oo

Scarlet (Acer rubrum). One of our handsomest Maples, growing to large size with moderately spreading branches. The leaves are three-to five-pointed, light green above, white beneath, changing to vivid shades of scarlet and gold in autumn. In early spring the bright red flowers are produced, followed by the equally highly colored seeds.

Silver (Acer dasycarpum). A Maple of very rapid growth, with large, five pointed leaves, green on the upper side and white, silvery colored beneath, turning pure yellow in fall. The branches are wide-spreading and rather drooping. Succeeds well everywhere. 


\section{GLEN SAINT MARY NURSERIES}

Shade Trees

Maple, Wier's Cut-leaved. A form of silver Maple, with deeply divided leaves. A rapid-growing tree with drooping branches. We recommend it highly. It grows well in southern sections. Each Per io 2 to 3 feet................... \$o 5o \$4 oo 3 to 4 feet.................... $60 \quad 5 \infty$ 4 to 6 feet....................... $75 \quad 6$ oo

MIMOSA TREE (Albizzia julibrissin). A small tree with low, spreading, flat-topped head and finely divided dark green compound leaves. Flowers pink, showy, borne in large bunches at the ends of the branches. A very handsome, rapid-growing tree, suited for planting throughout the South; hardy as far north as Washington.

$$
\text { Each Perio }
$$

I to 2 feet.................. \$o 30 \$2 50

2 to 3 feet.................. 40 350

OAK (Quercus). Long-lived, of rapid growth with graceful rounded tops. The Oaks are among our most valuable shade and ornamental trees. They can be grown almost anywhere, and no lawn or park is complete without a number of them. They are the most commonly planted of all our shade trees



Laurel (Quercus laurifolia). A medium- or large-sized tree, with thick, rounded head and slender branches. The leaves are oblong, sometimes lobed, dark green and shining. A handsome shade and avenue tree, native from Florida to Louisiana and Virginia.

Pin (Quercus palustris). One of the most beautiful Oaks, with symmetrical conical head and short, spreading branches. The leaves are bright green, becoming red in fall, five-to seven-lobed. In moist soil it grows rapidly and has proved to be well adapted throughout northern Florida and northward.

Scarlet (Quercus coccinea). A medium-sized Oak, with rounded open head. The leaves are very large, usually with seven wide, deep lobes. They turn bright scarlet in autumn. It grows well on rather dry soil.
Oak, Water (Quercus aquatica). The true Water Oak of the South, with slender spreading branches and rounded, rather conical head. The leaves are somewhat broader, and slightly three-lobed at the apex. A rapid grower and one of our most beautiful shade trees.

Willow (Quercus phellos). A rapid-growing symmetrical tree, with rounded head and narrow willow-like leaves. One of the most satisfactory Oaks.

PECAN (Hicoria pecan). A majestic tree rivaling the New England elm in stateliness and grandeur. Grows well throughout the cotton states and even farther north and west. Valuable for its nuts, and should be commonly planted, both for fruit and shade. See page 27 for prices.

PLUM, Flowering. A small tree with rounded, spreading top; flowers appearing before the leaves, pink, double; very handsome and showy; leaves wine-colored.

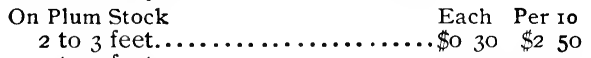
3 to 4 feet..................... $35 \quad 3$ co

Purple-leaved. For description and prices, see page I8.

POPLARS (Populus). Trees of rapid growth and valuable where quick shade is desired. Grow well under most adverse conditions.

Prices on Poplars Each Per Io Per 100 3 to 4 feet ............. \$o 25 \$2 oo $\$ 17$ oo

4 to 6 feet $\ldots \ldots \ldots \ldots \ldots \ldots .35 \quad 3$ oo 2500

6 to 8 feet.$\ldots \ldots \ldots \ldots \ldots$. $50 \quad 400 \quad 3500$

8 to ro feet $\ldots \ldots \ldots \ldots \ldots .96 \quad 90 \quad 750 \quad 65$ no

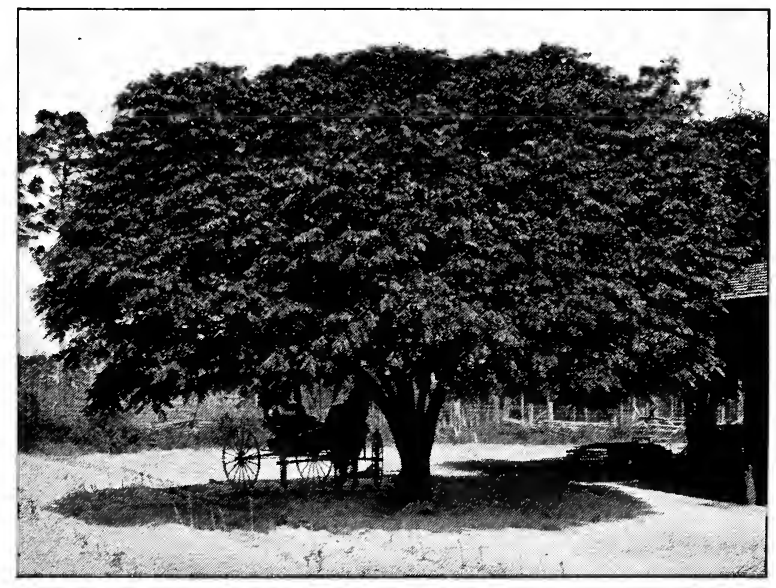

Texas Umbrella Tree (see page 40) 


\section{GLEN SAINT MARY NURSERIES}

\section{Shade Trees}

Poplars, Carolina (Populus Carolinensis). A very rapid-growing tree well adapted to moist soils, seashore locations and where a quick-growing tree is required. Leaves large, shining, tapering.

Cottonwood (Populus deltoides). A largebranched tree, with well-foliaged, symmetrical head. The leaves are large, triangular and bright green, borne on flattened petioles and are moved by the slightest breeze.

Lombardy ( $P$. nigra Italica). A straight upright growing tree of striking appearance. The leaves are small- or medium-sized, dark green with flattened petioles.

SYCAMORES. Stately trees with white bark, upright, spreading branches and symmetrical heads. They are rapid-growing trees, well suited for planting in trying locations. Each Per io Per 100 3 to 4 feet ........... \$o 25 \$2 oo \$17 oo 4 to 6 feet ............ $35 \quad 3$ oo 25 oo 6 to 8 feet $\ldots \ldots \ldots \ldots \ldots \ldots$ 50 $400 \quad 3500$ 8 to to feet ............ $75 \quad 6$ oo 55 oo

American (Platanus occidentalis). A noble tree with spreading branches and white or grayish bark. 'The leaves are large, lobed and toothed. A very rapid grower.

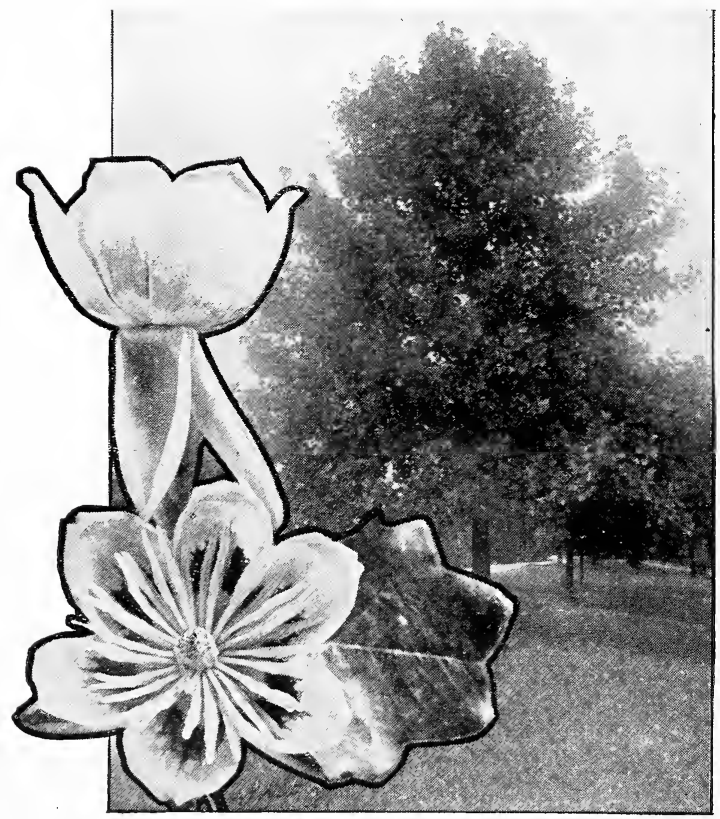

Tulip Tree
Sycamore, European (Platanus orientalis). A large tree with rounded head. Bark white; leaves large, 5- to 7-lobed.

RED BUD (Cercis Canadensis). A small tree, 20 to 30 feet high, with rounded handsome leaves, producing an abundance of rosy pink flowers in early spring. $\quad$ Each Per to 3 to 4 feet $\ldots \ldots \ldots \ldots \ldots \ldots \ldots \ldots \ldots$. 35 \$3 oo 4 to 6 feet $\ldots \ldots \ldots \ldots \ldots \ldots \ldots \ldots \ldots$ 50 450

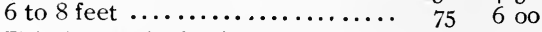

SWEET GUM (Liquidambar styraciflua). A rapid-growing native tree, with rather narrow symmetrical conical head. Branches often corky winged. Leaves bright green, five- to seven-pointed; in autumn brilliantly colored in shades of red and crimson. Each Per Io 3 to 4 feet $\ldots \ldots \ldots \ldots \ldots \ldots \ldots \ldots$. 5 o $\$ 4$ oo

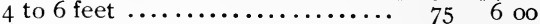

6 to 8 feet $\ldots \ldots \ldots \ldots \ldots \ldots \ldots \ldots$ I oo 9 oo 8 to ro feet $\ldots \ldots \ldots \ldots \ldots \ldots \ldots \ldots 2$ oo 15 oo Special size ............... 250

TALLOW TREE (Sapium sebiferum). A dwarf, spreading tree with poplar-like leaves, vivid gold and red in autumn. Seeds covered with wax used in Asia for candles.

Each Per Io

3 to 4 feet $\ldots \ldots \ldots \ldots \ldots \ldots \ldots \ldots$. $40 \ldots \ldots$

4 to 6 feet $\ldots \ldots \ldots \ldots \ldots \ldots \ldots \ldots \ldots$ 5o 450

TEXAS UMBRELLA. A medium-sized tree, with flat umbrella-like top. Foliage finely divided, dark green, casting a dense shade ; and is a very desirable shade tree.

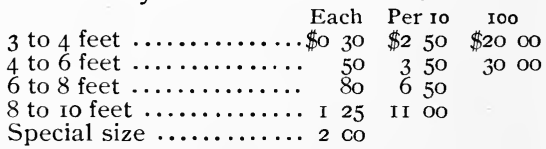

TULIP (Liviodendron tulipifera). An ornamental tree of pyramidal shape and rapid growth. The foliage is bluntly four-lobed, bright bluish green, turning bright yellow in autumn. The flowers are greenish yellow, marked with deep orange, tulip shaped. A handsome tree of clean growth, free from insects and diseases; one of the most desirable for park and lawn planting.

\begin{tabular}{|c|c|c|c|}
\hline & Each & Per ro & IOO \\
\hline 4 feet.. & $\$ 040$ & $\$ 350$ & $\$ 3000$ \\
\hline 6 feet $\ldots$. & 50 & 450 & 400 \\
\hline 8 feet $\ldots \ldots \ldots$ & 75 & 600 & 5000 \\
\hline to io feet............ & I OO & & \\
\hline
\end{tabular}

WEEPING WILLOW (Salix Babylonica, var. pendula). Reaches a height of 30 feet, with pendulous branches and narrow leaves. Valuable for planting along streams, the margin of ponds, or for lawn specimens. Each Per ro 2 to 3 feet $\ldots \ldots \ldots \ldots \ldots \ldots \ldots \ldots \ldots$. 20 \$I 50 3 to 4 feet $\ldots \ldots \ldots \ldots \ldots \ldots \ldots \ldots$, 30 . 2 oo 


\section{GLEN SAINT MARY NURSERIES}

\section{Conifers}

\section{ARBORVIT ÆS AND OT HER CONIFERS}

These plants make beautiful individual lawn specimens. The different colors-yellow' green, dark green and blue green-give a striking effect when planted in masses, either when groups are made up of a single kind or of a number of different kinds. They make an excellent background for other shrubs.

As plants for porches or porch steps, they are very satisfactory. They are hardy and longlived. We have tested the list offered for many years and know they will give satisfaction.

ARBORVIT E (Thuya, Biota). Beautiful evergreen shrubs of compact symmetrical growth; especially suited for formal plantings. The varieties we list are adapted to southern climatic and soil conditions.

Aurea nana. A variety with compact rounded head and handsome greenish golden foliage. See back cover page.

I to $\mathrm{I} x / 2$ feet..................

I $1 / 2$ to 2 feet................. 50 450

2 to 3 feet...................... $75 \quad 6$ oo

3 to 4 feet................... I oo 9 oo

Pyramidalis. Upright and narrow, growing to a good height, with beautiful, light green foliage. One of the most striking Arborvitæs, a rapid grower; very fine for formal plantings.

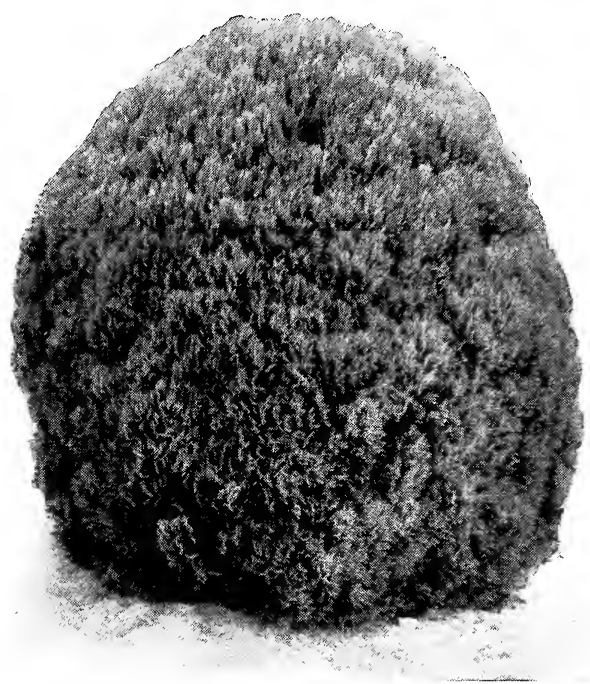

Rosedale Arborvitae

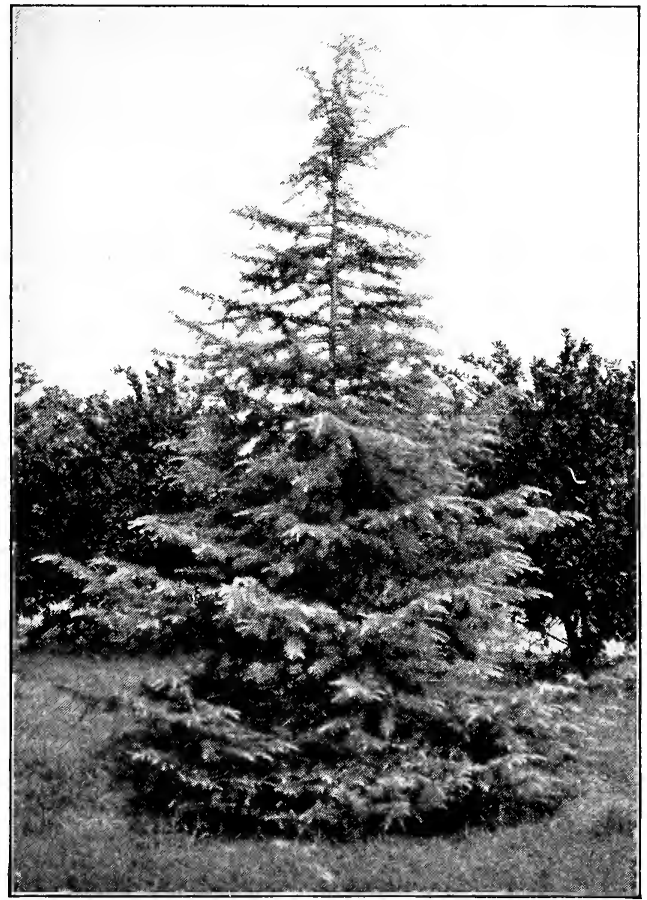

Cedrus deodara

Arborvitæ Pyramidalis, continued. Each Per ro I to 2 feet.................. \$o $35 \$ 3$ oo 2 to 3 feet.................. $45 \quad 4$ oo 3 to 4 feet................. $85 \quad 7$ oo Special size............... 3 oo 2000

Rosedale. Of compact rounded, symmetrical form with very dense head. The foliage is dark, bluish green and very handsome. Very desirable for the South. Each Per io I to 2 feet................ 35 o 35 oo 2 to 3 feet.................. $45 \quad 4$ oo 3 to 4 feet................... 8 o 7 oo 4 to 5 feet.................. I 50 I2 00 Special size................ $255^{\circ}$

CEDRUS deodara (Indian Cedar). A conebearing tree introduced from the Himalayan mountains. Of pyramidal form, reaching immense proportions. Foliage a beautiful shade of bluish green. This tree is well adapted to the southern states and makes an exceedingly handsome lawn specimen.

Each Per io I to 2 feet............... 2 to 3 feet.................. 75 oo 3 to 4 feet................... I oo 9 oo 4 to 5 feet................ I 50 I 2 50 


\section{GLEN SAINT MARY NURSERIES}

\section{Conifers}

JUNIPERUS Virginiana (Red Cedar). A dark green tree, with conical head and upright spreading branches. It grows rapidly and reaches a large size. It should be planted in a sunny exposure.

Each Per io 2 to 3 feet................\$o $35 \$ 3$ oo

3 to 4 feet................. 50 400

4 to 5 feet................... $75 \quad 6$ oo

5 to 7 feet................. I oo 9 oo

Special size................ 3 oo
RETINOSPORA plumosa (Japan Cypress). One of the most valuable of the Japanese Cypresses. A rapid-growing variety with feathery, plume-like foliage and slender branches. It makes a very handsome tree and succeeds well in the South.

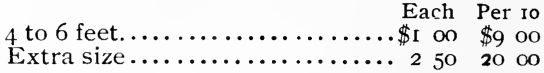

\section{SHRUBS AND HEDGE PLANTS}

Nothing adds so much to the beauty of the home surroundings, nothing gives so much pleasure as a good lawn and well-placed shrubs and vines. The number which may be planted will be governed by the shape and extent of the grounds, but even the smallest lot has a place for a few. They should be planted in masses, in corners and about the buildings, always leaving a goodly proportion of open lawn. Aside from their value in beautifying the grounds, they actually increase the money value of a property. A city lot, for instance, with well-grown shade trees and shrubs, is decidedly more valuable than a piece of bare ground.

The varieties offered are those which have been thoroughly tested and which we know will give satisfaction. Our stock is healthy, vigorous and well grown.

ABELIA grandiflora. A beautiful evergreen shrub with dark green glossy leaves becoming bronze-colored in winter. Flowers white, funnel-shaped, tinged with pink, delicately sweet-scented, borne in clusters throughout the whole season, from early spring until late autumn. One of our handsomest shrubs.

Each Per io I-year plants.............. \$o 30 \$2 50 2-year plants ................ 40 350

ALTHAA (Hibiscus Syriacus). Rose of Sharon. This is one of our most desirable flowering shrubs. The top is rather upright and
Althæa, continued

spreading. They are easily grown and produce an abundance of bloom throughout a long period.

Each Per ro

I to 2 feet $\ldots \ldots \ldots \ldots \ldots \ldots \ldots \ldots \ldots$ \% 20 \$I 50

2 to 3 feet $\ldots \ldots \ldots \ldots \ldots \ldots \ldots \ldots$. $25 \quad 2$ oo

3 to 4 feet $\ldots \ldots \ldots \ldots \ldots \ldots \ldots \ldots \ldots$ 40 $355^{\circ}$

4 to 6 feet $\ldots \ldots \ldots \ldots \ldots \ldots \ldots \ldots$, 50 450

Carnea plena. Double white, with red throat; a free bloomer.

Rubra. Double red, large, free-flowering and a very handsome shrub when in full bloom.

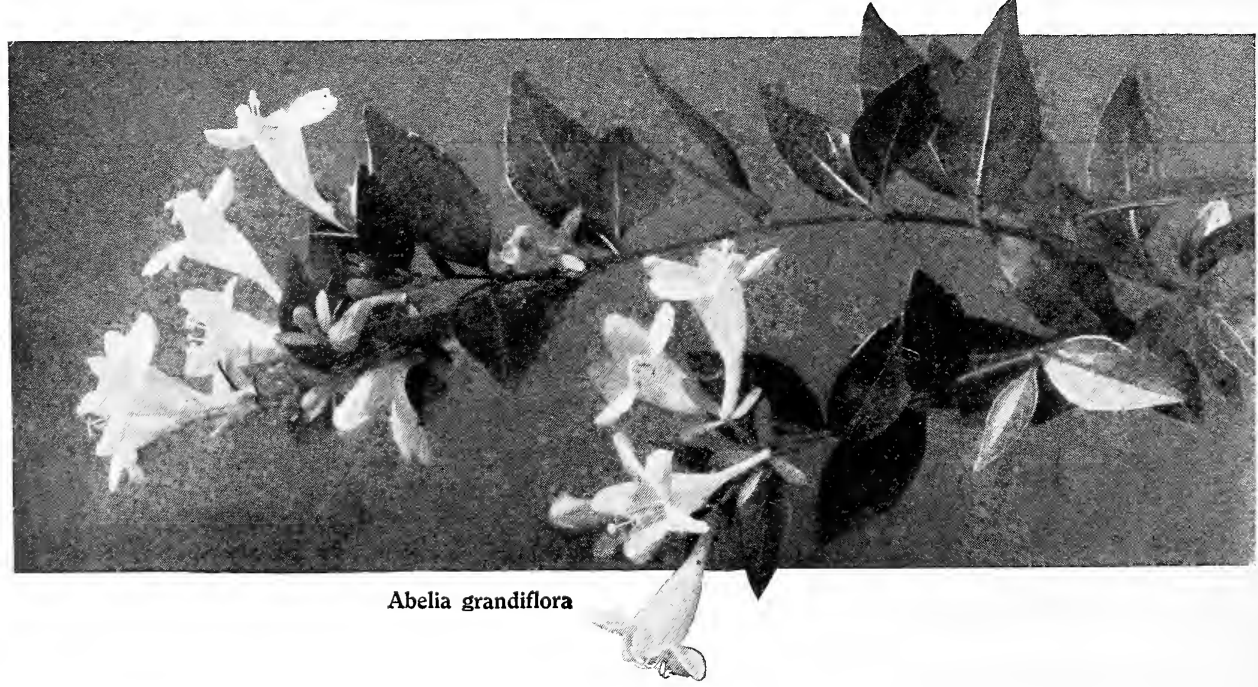






White Crape Myrtle Border

BARBERRY (Berberis Thunbergii). A lowgrowing shrub, spiny, with bright green foliage which becomes beautifully colored in autumn. The white flowers are followed by bright, shining red fruit. One of the most beautiful shrubs.

I to 2 feet................. 18 \$ $\$$ I 50

2 to 3 feet.................. $25 \quad 2$ oo

CAMELLIA (Camellia Japonica). Handsome evergreen shrubs with bright shiny green leaves. Free-flowering and very desirable. No southern garden should be without this grand flower. We offer three double varieties, red, variegated and white.

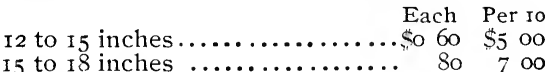

CAPE JESSAMINE (Gardenia florida). An evergreen shrub, with dark green, glossy leaves. The flowers are white, waxy, very fragrant, large and showy. It blooms from May to September and reaches a height of 8 to I 2 feet. I $1 / 2$ to $21 / 2$ feet 25 cts. each, $\$ 2$ per Io.

CHERRY LAUREL (Prunus Caroliniana). This small tree makes a handsome, durable hedge, the bright glossy evergreen foliage giving it an exceedingly pleasing appearance. Plants should be set about $I_{5}$ inches apart, and may be trimmed in rectangular or rounded form.

I to 2 feet $\ldots \ldots \ldots \ldots \ldots \ldots \$ 020$ \$I $50 \quad \$ 1200$

2 to 3 feet.............. $25 \quad 2$ oo 18 oo
CRAPE MYRTLE (Lagerstramia Indica). Vigorous deciduous shrubs, reaching a height of I 5 to 20 feet; leaves small, bright green. The fringed flowers are produced in immense clusters in different shades of white, purple and scarlet; of easy culture and one of the most conspicuous southern shrubs.

Each Per io roo

2 to 3 feet............. \$o $25 \quad \$ 2$ oo $\$ 1 ;$ oo

3 to 5 feet.............. to 3 oo 25 oo

5 to 7 feet $\ldots \ldots \ldots \ldots \ldots \ldots$. $75 \quad 7$ oo 60 oo

Special size ........... I oo 9 o

Purple. A grand sort, producing immense clusters of flowers of a rich purple color.

Scarlet. Of handsome growth; a bright showy plant with large bunches of scarlet flowers.

White. A pure white form with large clusters of flowers, very free-blooming.

ELÆAGNUS edulis. A low-growing shrub with silvery leaves; flowers light yellow, borne singly along the branches. Fruit bright red, produced in summer.



FRENCH MULBERRY, White (Callicarpa Americana alba). A deciduous shrub with dark green leaves and upright stems. Fruit pure white, produced in compact bunches at the bases of the leaves. Easily grown.

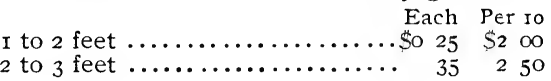




\section{GLEN SAINT MARY NURSERIES}

Shrubs and Hedge Plants

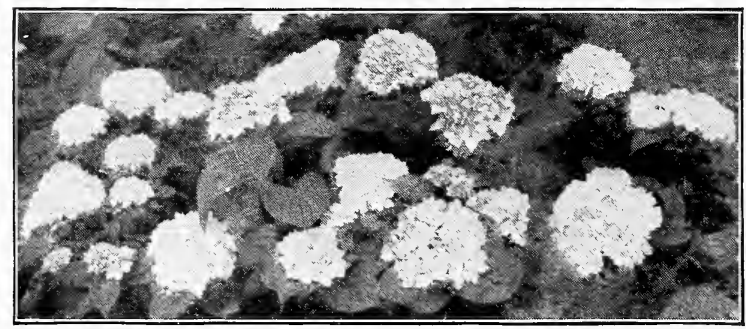

Thomas Hogg Hydrangea

HYDRANGEA. A very ornamental group of shrubs with showy flowers, produced in large bunches. They are excellent for planting in masses.

arborescens. A hardy, upright shrub, reaching a height of 6 or 8 feet ; flowers yellowish white, borne in early spring, in flat clusters. A desirable shrub.

paniculata grandiflora. A very showy form, producing immense clusters of flowers a foot or more in length, white, becoming slightly rose-colored. One of the best shrubs in cultivation. Reaches a height of 6 or 8 feet.



Thomas Hogo. A handsome, dwarf variety, growing in dense, compact form with large, bright green leaves. Produces large rounded clusters of white flowers.

Each Per Io

I-year............ \$o $35 \$ 3$ oo

2 -year.............. 50 o 4 oo

3-year................... 60

MOCK OR A NGE (Philadelphus grandiflora). A handsome tallgrowing shrub, with narrow, oval green leaves. The flowers are white and produced in mediumsized clusters.

Each Per in

I to 2 feet $\ldots \ldots \ldots \ldots \ldots$. 30 o $\$ 250$

2 to 3 feet ............ 35 oo

3 to 4 feet $\ldots \ldots \ldots \ldots \ldots$ 50 4 oo

4 to 6 feet ........... $75 \quad 6$ oo

POMEGRANATE, Flowering (Puni-

$c a$ ). These shrubs are among the most satisfactory for general planting. Beautiful flowers in various shades of white, pink and red produced all summer.

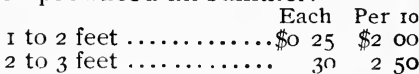

2 to 3 feet $\ldots \ldots \ldots \ldots \ldots \ldots$ 3n 250

3 to 5 feet $\ldots \ldots \ldots \ldots \ldots$. 50 450
Pomegranate, Double Scarlet. Has large, bright scarlet flowers; a strong-growing variety.

Double White. A strong-growing variety with long, double creamy white flowers.

Dwarf Scarlet. A compact dwarf variety with small bright scarlet flowers. Very handsome.

Mad. Legrelle. Pink, marked with crimson veins, very full and double.

PRIVET, Amoor River (Ligustrum Amurense). A densely branched variety of rapid growth, with small evergreen leaves. The best hedge Privet known, and may be pruned in any desired form. Very ornamental when grown as an individual specimen. This is the best hedge Privet, either North or South. Each Per ro roo 1,000 I-year........... \$o I5 \$I Oo $\$ 5$ oo $\$ 35$ oo 2-year............ 25 I 50 o 9 oo 55 oo

SPIR EAS. These shrubs bear a profusion of showy flowers in early spring. They are very hardy, thrive well in moist, fertile soils, and are well adapted for southern planting.

Each Per ro

I-year.................... \$o 30 \$2 50

2 -year.................... 35 oo

3 -year..................... 50 4 oo

Cantoniensis. A compact branching shrub, 3 to 4 feet in height, producing a dense mass of pure white flowers, very handsome and desirable.

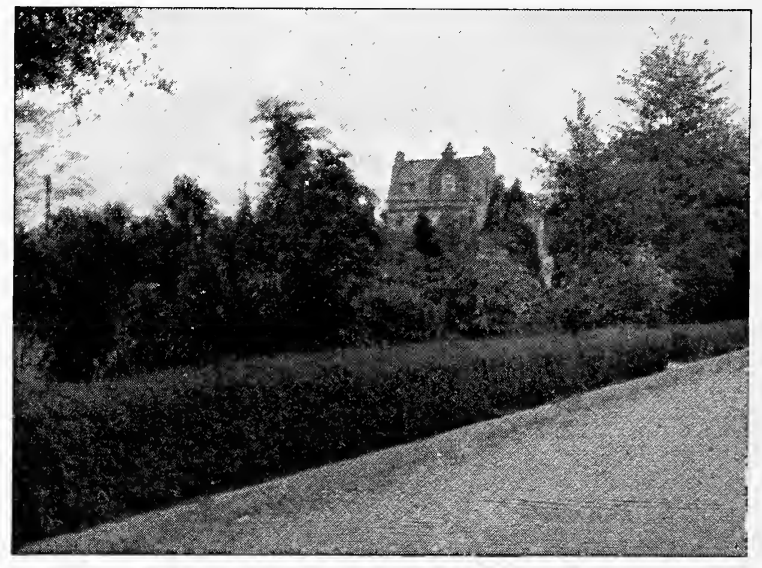

Amoor River Privet Hedge 



Spiraea Cantoniensis

Spiræas Van Houttei. Branches long and arching; leaves dark green; flowers produced in clusters along the branches; hardy. A splendid plant for mass effects.

SWEET SHRUB (Butneria florida). A deciduous shrub, highly esteemed for its large, reddish sweet-scented flowers, which are produced in early spring. The leaves are large, dark green, and the plant reaches a height of about five feet. Grows well in shade.





TRIFOLIATA ORANGE (Citrus trifoliata) A small-growing, hardy variety of Orange, with sweet-scented flowers appearing in spring before the leaves. Of dense, upright form and very thorny. Fruit round, golden, ripening in autumn and remaining on the trees for two or three months after coloring. A handsome tree, and makes an impenetrable hedge. Very valuable and hardy, withstanding temperatures below zero.

WHITE FRINGE (Chionanthus Virginica). A large shrub or small tree, with dark green leaves. Flowers white in loosely branched clusters. Native throughout the South and easily grown.



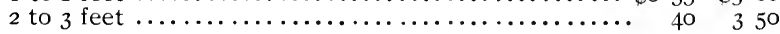

\section{BAMBOOS, GRASSES, ETC.}

In giving a tropical effect to the grounds, no plants are more useful or desirable than the bamboos and taller growing grasses. Their long willowy canes and fine foliage make a very pleasing effect. They are also useful as screens for unsightly objects and for tall hedges.

The list which we are growing has been carefully tested for hardiness and general beauty. They will stand temperature of twelve to fifteen degrees or lower. IVe are certain they will give satisfaction.

Prices on Arundo donax, Arundinaria falcata, Bambusa argentea, argentea striata, aurea, metake, verticillata.

Small clumps, ............................\$o 35 \$3 o



Extra-strong clumps........................ to 200

ARUNDO donax variegata. A strong-growing grass. Stems 8 to I2 feet high. Leaves large, green with stripes of creamy white. Plumes large and showy. Very hardy.

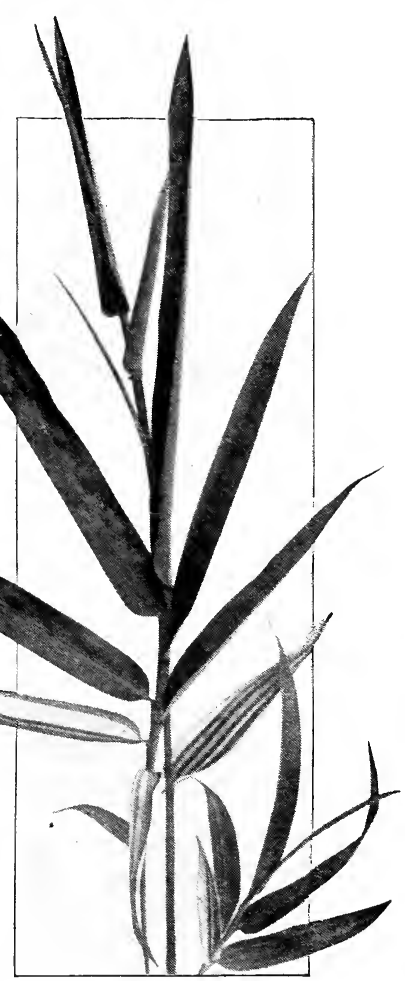

Bambusa argentea striata 


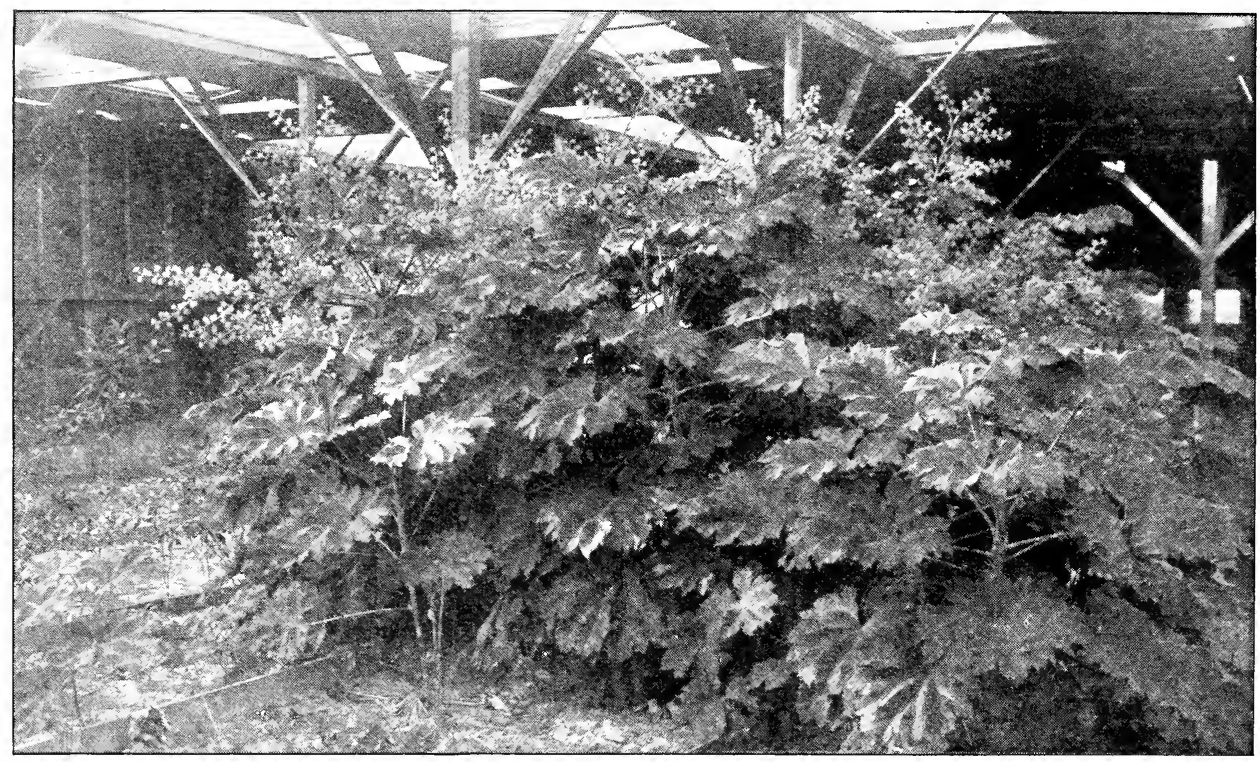

Clump of Japanese Paper Plant

ARUNDINARIA falcata. A very graceful Bamboo, reaching a height of to to 12 feet. Grows in dense thick clumps; leaves fern-like. Very hardy.

BAMBUSA argentea. This very desirable variety reaches a height of 30 to 40 feet with graceful spreading top. Very hardy.

Argentea striata. This variety is the same as Argentea, except the leaves are beautifully striped green and white. A strong grower. Hardy.

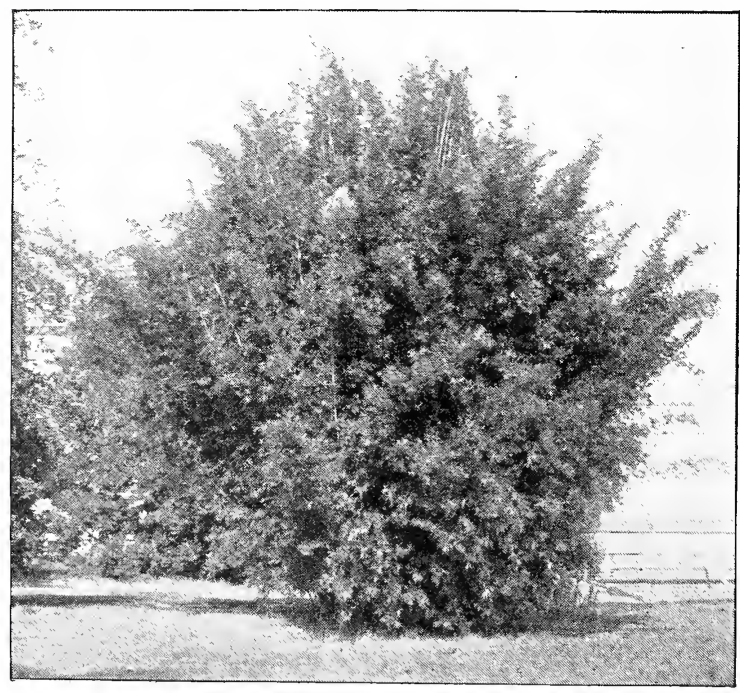

Clump of Bambusa argentea
Aurea. Stems yellow, reaching a height of Io to I 2 feet. Root stocks spreading underground. Branches open spreading. Hardy.

Metake. A handsome broad-leaved Bamboo, reaching a height of Io feet. Grows in large dense masses. Very ornamental. Hardy.

Verticillata. Canes striped yellow, reaching $\mathrm{I}_{5}$ or 20 feet. Makes fine clumps and very hardy.

PAPER plant (Aralia papyrifera). A very ornamental plant with large leaves shaped something like those of the castor bean. Splendid for clumps and borders. Strong plants, 25c. ea., $\$ 2$ per Io.

YUCCA filamentosa (Adams needle, or Bear Grass). A native plant with long, green leaves borne in a dense clump. Flowering stems 4 to 6 feet high bearing in profusion, drooping creamy white flowers. Very hardy and desirable.

Each Per ro I-year..............\$o 30 \$2 50 2-year.............. 40 350 


\section{GLEN SAINT . MARY NURSERIES}

\section{VINES}

HONEYSUCKLES (Lonicera). Rapid-growing vines, with handsome flowers. They make a dense covering and are especially adapted for porches, trellises and for hiding unsightly places.

Each Per Io I-year...................\$o $25 \$ \$ 200$ 2-year.................... $35 \quad 3$ oo

Trumpet (Lonicera sempervirens). A beautiful, strong-growing vine, with oval leaves, bluish green in color. Flowers showy, scarlet on the outside, yellow within, large and produced throughout nearly the whole year with us. Even in winter it continues in bloom.

White (Lonicera Japonica). A rapid-growing vine, with slender stems, and dark green leaves. Flowers white, changing to yellow as they fade. Produces a dense covering.

JAPAN IVY (Ampelopsis Veitchii). A beautiful rapid-growing vine, with three-lobed or three-parted dark glossy green leaves. A very beautiful vine, especially adapted for covering brick and stone walls. One-year well-grown vines, 25 cts. each, $\$ 2$ per Io.

TRUMPET VINE (Bignonia radicans). A strong-growing vine, with dark green compound leaves. The flowers, brilliant orange in color, are borne in clusters during the
Taumpet Vine, continu ed summer months. The Trumpet Vine is valuable as a quick-growing cover for trellises, fences or any unsightly object. 2 to 3 feet, 30 cts. each, $\$ 2.50$ per Io.

VIRGINIA GREEPER (Ainpelopsis quinquefolia). A hardy, rapid.growing vine; leaves deciduous dark green, five-parted, gorgeously colored red and scarlet in fall. A splendid vine for walls, arbors and porches.

Each Per ro I-vear plants ................ \$O $25 \quad \$ 2$ cO 2-year plants .............. $30 \quad 250$

WISTARIA (Wistaria Chinensis). A magnificent strong-growing vine, hardy throughout the country. The flowers, which appear before the leaves in spring, are produced in large, pointed clusters.

2 to 3 feet..................\$ $25 \$ 200$ 3 to 4 feet................. to 3 oo

4 to 6 feet.................. 60 5 oo

YELLOW JESSAMINE (Gelsemium sempervirens). A slender, rapid-growing evergreen vine, with dark green leaves. The flowers are yellow, fragrant and produced in profusion during the spring months. Oneyear vines, $20 \mathrm{cts}$. each, $\$ 1.50$ per Io.

\section{PROPER DISTANCES FOR PLANTING}

Oranges on common stocks . . . . . . . . . . . . . . 25 to $30 \mathrm{ft}$ each way Oranges on $C$. trifoliata . . . . . . . . . . . . . . I8 to $20 \mathrm{ft}$. each way Kumquats . . . . . . . . . . . . . . . . . Io to I2 ft. each way Peaches and Apples . . . . . . . . . . . . . . . . . 18 to $20 \mathrm{ft}$. each way Plums .................... . . . . . . . . 5 to $18 \mathrm{ft}$ each way Japan Persimmons . . . . . . . . . . . . . . . . . . I 5 to $20 \mathrm{ft}$ each way Pears, Le Conte . . . . . . . . . . . . . . . . . . . . . . . 25 to $30 \mathrm{ft}$, each way Pears, General varieties . . . . . . . . . . . . . . 20 to $25 \mathrm{ft}$. each way Grapes, Bunch varieties . . . . . . . . . . . . . . . 8 to Io $\mathrm{ft}$ each way Grapes, Muscadine type . . . . . . . . . . . . . . . I 8 to $25 \mathrm{ft}$. each way Figs . . . . . . . . . . . . . . . . . . . I 2 to I $5 \mathrm{ft}$ each way Pecans . . . . . . . . . . . . . . . . . . . 40 to $50 \mathrm{ft}$ each way

\section{NUMBER OF TREES OR PLANTS TO THE ACRE}

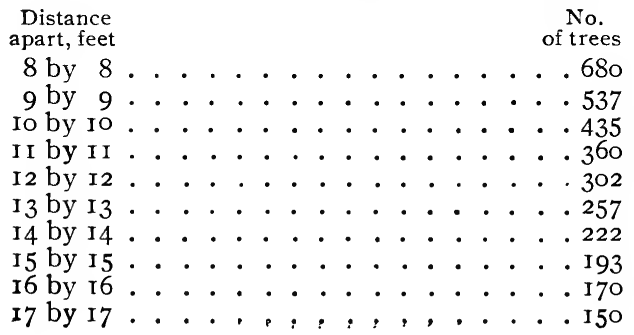

Distance

I 8 by i 8

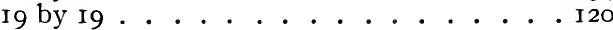



22 by $22 . . . . . . . . .990$

25 by 25 ........... . . 69



35 by $35 . . . . . . . .35$

40 by $40 . . . . . . . . . . .227$

45 by $45 \ldots . . .2 . . .21$

50 by $50 \ldots . . . . . . . .17$ 


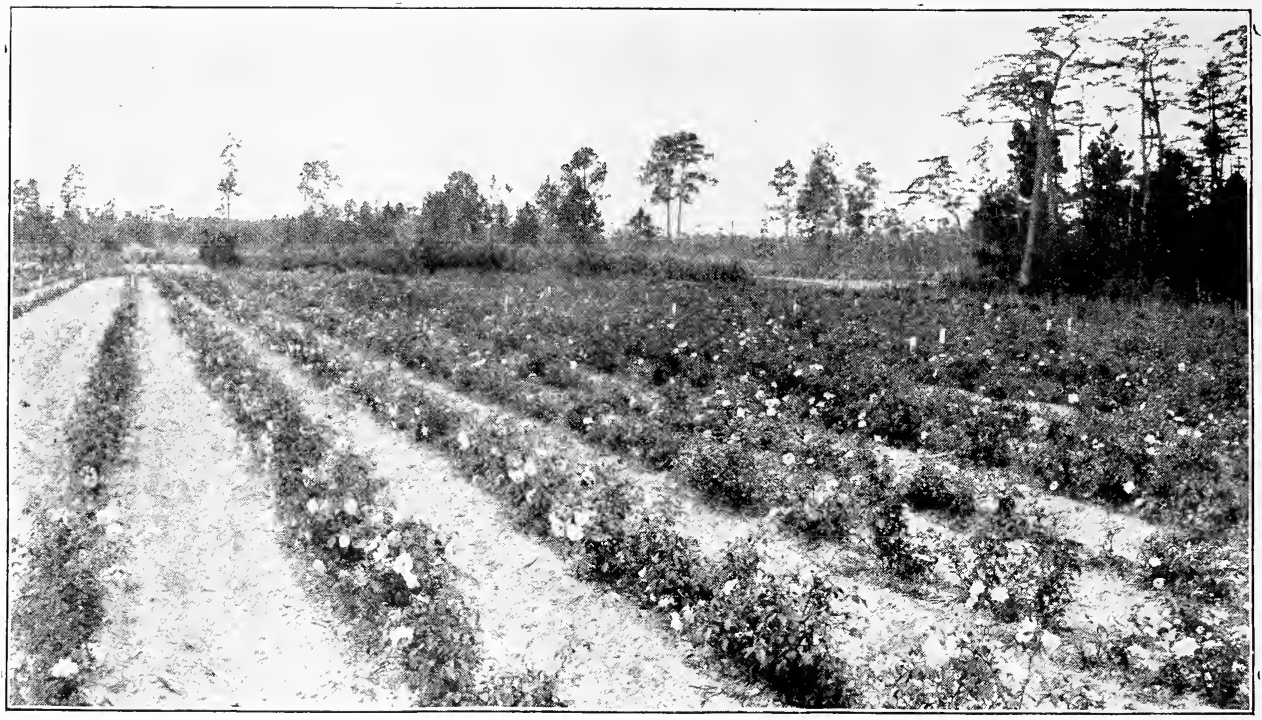

Partial view of the Rose Nursery

\section{Terms of Business}

Location. Our Nurseries are one and one-half miles southwest of Glen Saint Mary, Baker county, Florida, a station on the Seaboard Air Line Railway, thirty miles west of Jacksonville.

Long Distance Telephone in our office.

Glen Saint Mary is a freight, express and telegraph station.

Invitation to Visitors. - We take pleasure in showing our stock to persons wishing to purchase, and, if notified in time, will meet visitors at the station on arrival.

No Agents. - We employ no agents, and have no connection with any other nursery. Trees sold to dealers must be resold by them upon their own responsibility. We are responsible only to parties purchasing direct from our Nurseries.

Club Orders. - Neighbors can sometimes club together and have one of their number place order for all, thus often securing lower prices on account of larger number of trees ordered.

Minimum Orders. - We do not care to accept orders amounting to less than $\$ 2$.

Applying Prices.-Five, fifty and five hundred trees of one class at ten, hundred and thousand rates, respectively, purchaser's selection from varieties of one fruit having a common price. For instance, fifty or more peaches, in one or more varieties, would come at the hundred rate, and five hundred or more at the thousand rate. The foregoing does not apply to badly assorted orders, or to long lists made up of a few each of many varieties.

Terms Cash with order, if for immediate shipment. Orders for trees to be held for some weeks after the shipping season opens should also be accompanied by full payment. On orders booked in advance of the shipping season 25 per cent down, with the balance due when the shipping season opens. We do not care to ship trees C. O. D.

Remittances.-To secure safety and prompt acceptance, remittances should be made by Bank Draft, Express or Post Office Money Order, Registered Letter or Prepaid Express.

Method of Shipment.-Shipping directions should be plainly written and we urge our customers in all cases, to use our order sheets. We shall be pleased to forward additional ones upon 


\section{GLEN SAINT MARY NURSERIES}

Terms of Business

application. Kindly indicate whether shipment is to be made by freight, express or mail. When method of shipment is left to us, or when no directions are given, we will ship according to our best judgment, by such means as we believe to be in the best interests of our customers.

Our stock is well and carefully packed in paper-lined boxes and bales. For this, no extra charge is made, and neither time nor expense is spared in packing the trees in such shape that they will open up in good fresh condition.

Transportation at Purchaser's Risk and Expense.-All transportation charges are to be paid by the purchaser, and our responsibility ceases upon delivery, in good order, to forwarding companies; claims for losses or damages must be made upon the latter. We will, however, start a tracer for delayed shipments, if notified, and use every means at our command to secure prompt delivery, or recovery in case of damage or loss.

Shipping by Mail. - In ordering trees or plants for shipment by mail, add 5 per cent to the list price on the smallest size given, to cover cost of packing and postage. We cannot guarantee trees to come up to size specified in list, as only very small specimens can be sent in this way.

Time of Shipment.-Unless instructed otherwise, orders received during the shipping season will be forwarded as soon after their receipt as possible, and orders booked in advance will be shipped as soon as may be after the shipping season opens.

The Shipping Season.-November to March for all trees and plants. Citrus trees can, however, be shipped at any season of year, but, when forwarded during summer months, should be shipped by express.

Selecting Varieties suited to locality is of the first importance, and can often be more advantageously done by ourselves than by purchasers. We are always glad to aid our customers in their selections, when so desired, and will, upon request, cheerfully furnish additional information in regard to the adaptability or desirability of particular varieties.

Substitution.-We desire to follow our customers' wishes in this respect, and have found that they generally wish us to substitute, to the best of our judgment, in case any varieties or sizes ordered are exhausted. We, therefore, substitute when necessary unless instructed to the contrary.

Printed Labels attached with brass wire to everything sent out.

We Guarantee all stock sent out to be well-rooted, well-grown, true to name, properly packed, and shipped according to instructions. Our liability under the foregoing guaranty is limited in amount to the original price received.

Claims.-If, by any possibility, errors should occur, they will be promptly rectified, if claim is made within ten days after the receipt of the goods.

\section{FLORIDA STATE HORTICULTURAL SOCIETY'S REPORTS}

At the annual meeting of the Florida State Horticultural Society, numerous papers and reports containing the most advanced thought of up-to-date, practical horticulturists are presented. The discussions following these reports bring out many valuable points. These papers, reports and discussions are reported verbatim and published in book form. These books are mailed to members of the society. Any one may become a member by paying $\$ \mathrm{r}$ membership fee.

The I909 Report will be mailed to any one remitting $\$$ I for it. 


\section{GLEN SAINT MARY NURSERIES}

\section{Brief Hints on Tree Planting}

Soil on which trees are to be set should be thoroughly prepared before planting. A crop of beggarweed, velvet beans or cowpeas grown on the land the previous season makes an excellent foundation. Plow and pulverize the ground well before planting.

Set stakes where the trees are to stand. Make the rows straight. The orchard will look better and the trees will be easier to care for.

Dig the holes six inches deeper and wider than the spread of the roots.

When trees are received, open the boxes or bales and heel the trees in a shady place. Dig out a trench straight down on one side, sloping out to the ground level on the other, and deep enough to hold the roots of the trees. Place the trees in the trench side by side, cover the roots with earth and pack well around them.

Trees should not be left long and are best heeled in only during the time of planting. Do not allow the roots to be exposed to sun or wind at any time. Keep them covered.

Prune off broken roots and cut back the tops if they have not already been cut back. Trees will start off much better if well pruned at time of planting.

Set trees at the same depth as they stood in the nursery rows. The earth marks on the collar can be taken as a guide. Use top soil for filling in the holes. Pack the earth tight around the roots with the hands and fingers. A pound of good commercial fertilizer thoroughly mixed in the earth with which the holes are filled can be used to good advantage. Do not use stable manure in planting trees.

If soil is dry, water may be used to advantage, a bucketful or more. Apply the water when the hole is three-quarters filled in. When the water has sunk away, fill in the remainder of the hole with earth, pack well and rake the surface, to leave the earth loose on top.

\section{INDEX}



.

French Mulberry..........43 Grape Fruit $\ldots \ldots \ldots \ldots \ldots .9$, Io Grapes ..............25, 26

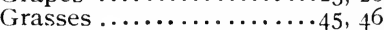
Guava.................... Hackberry ................. 37 Hedge-plants...........42-45 Holly.................... 38 Honeysuckle ..............47 Hydrangea...$\ldots \ldots \ldots \ldots \ldots 44$ Ilex opaca $\ldots \ldots \ldots \ldots \ldots \ldots \ldots 3^{8}$ Indian Cedar............. $4 \mathrm{r}$ Japan Ivy $\ldots \ldots \ldots \ldots \ldots \ldots \ldots 47$ Japan Persimmons .......20, 2I Japan Walnut .............28 Japan Cypress.............. 42 Jessamine, Yellow..........47 Juniperus............... 42 Kumquat ............... 8 Lemons.$\ldots \ldots \ldots \ldots \ldots \ldots$, I I Limes................... Io Lombardy Poplar............ $4^{\circ}$ Lonicera.................47 Loquat $\ldots \ldots \ldots \ldots \ldots \ldots \ldots \ldots 24$ Magnolia .................... $3^{8}$ Maples ..................... 39 Mimosa Tree................. 39 Mock Orange.............. 44 Mulberries...............23 Muscadine Grapes...........25 New Fruits .............. I, I2 No Agents................ $4^{8}$ Number of trees to the acre...47 Oaks ....................... 39 Oranges .................... Paper Plant.................46 Peaches..............12, I3 ${ }^{-1} 7$ Pears................... Pecans . . . . . . . . . 26-28, 39 Persian Plum.............. i 8 Persimmons ............... 20 Philadelphus grandiflora ..... 44 Plums ..........12, 17-19, 39 Pomegranates ..........22, 44 Pomelo $. . . \ldots \ldots \ldots \ldots . . \cdots$. Io, II Poplars ............... 49 Privet.$\ldots \ldots \ldots \ldots \ldots \ldots \ldots \ldots 44$ Prunus Caroliniana.............37 Quercus..................... 39

Quinces ...................... 34

Red Bud...................40

Red Cedar................42

Retinospora plumosa........42

Rose of Sharon............42

Roses .................29-36

Shade Trees..............36-40

Shrubs ............... 42-45

Spiræas $\ldots \ldots \ldots \ldots \ldots \ldots \ldots \ldots . \ldots \ldots$

Sweet Gum................. to

Sweet Shrub..............45

Sycamores...............

Tallow Tree................ 40

Terms of Business........... 48

Texas Umbrella Tree........ 4o

Trifoliate Orange........... 45

Trumpet Vine.............47

Tulip Tree ...............

Varnish Tree................. $3^{8}$

Vines....................47

Virginia Creeper........... 47

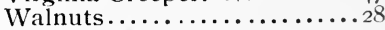

Weeping IVillow........... 40

White Fringe............. 45

Wistaria ..................

Yucca $\ldots \ldots \ldots \ldots \ldots \ldots \ldots \ldots 4^{6}$ 




An orange which is bound to revolutionize the growing of oranges in Florida and adjacent citrus sections 


\section{The Lue Gim Gong Orange}

This season we are introducing to our customers a new Orange, known as Lue Gim Gong, a late round Orange of unusual merit. During the past quarter of a century or more, a number of new varieties of fruits have been introduced by the Glen St. Mary Nurseries. As a rule, these varieties of fruits of different kinds have made good, and some of them are today the leading varieties in the regions to which they are adapted. We are confident that the Lue Gim Gong Orange will become the most noted late Orange in the country. It will far surpass in value and in reputation any other variety of any kind of fruit we have ever introduced.

ORIGIN. In I $886 \mathrm{Mr}$. Lue Gim Gong, De Land, Fla., pollinated Harts Late with pollen from



Mr. Lue Gim Gong and One of His Trees what was believed to be a Mediterranean Sweet Orange tree. One Orange containing fifteen to eighteen seeds resulted from the crossing. From these seeds about twelve trees were raised no two of which proved to be alike.

The variety, now called Lue Gim Gong, when it came into fruit, seemed to be such an improvement on Harts Late that Mr. Lue budded fifteen trees with this variety on one side, and Harts Late (Tardiff) on the other. About thirty other trees were budded with this variety on one side, and other varieties on the other. Five trees are now solid.

DESCRIPTION. Size large, packing I 26 to 176 per box; form oblong, carrying the size well out to the rounded ends; color deep orange-red; skin thin, smooth on current crop, becoming rougher on two- and three-year-old fruit; sections well defined, ten or eleven in number; flesh deep orange; juice sacks large; juice abundant, even in old specimens; seeds few, usually four to eight; flavor a rich blending of sweet and sub-acid; quality best. A fine shipping fruit and a good keeper. Tree and fruit both very hardy and resistant to cold.

COMPARISONS. At this time, Harts Late is the standard late Orange of Florida, and it may therefore be well to make comparisons between this new variety and the standard sort. On July 6, I909, Mr. Lue took fifteen boxes of Harts Late (from one side of above trees) to the packing-house and, after testing for specific gravity by placing them in water, packed five boxes out of the fifteen. These were considered to have enough weight for shipping. The five boxes were shipped to North Adams, Mass. Upon arrival they had to be repacked at a cost of 35 cents per box, and then only three boxes remained, which sold for $\$ 2.50$ per box.

At the same time, five boxes were picked of the Lue Gim Gong Orange from the other side of the same trees. The fruit was not tested for specific gravity, and all the fruit was shipped. On arrival at North Adams, they did not require repacking, and the whole five boxes brought $\$ 4.5^{\circ}$ per box.

The Lue Gim "Gong Orange is a hardy, thrifty-growing variety. It can be marketed to advantage in August, September and October, when other varieties are out of season, and when the only fruit on the markets is Valencia Late, from California.

The fruit hangs on the trees with very little dropping through the rainy season, which in Florida usually begins in June and lasts several weeks. The fruit has been known to hang on the trees, one, two and even three years, in an edible state. There is no question but that this variety marks the beginning of a new era in late Orange culture. 
So convinced are we of the merits of this Orange that we have entered into a contract with Mr. Lue Gim Gong for control of the variety. The contract price for the variety we believe far exceeds the price paid for any other Orange, or for any other fruit ever propagated in America. We are preparing to plant heavily of it ourselves in the southern part of the state.

The tree is hardy and vigorous. Planted in the grove of Mr. Lue Gim Gong, near DeLand, Fla., with other varieties of Oranges, it has stood the cold for years past better than any other variety in the grove, and has passed through the several cold snaps practically without injury. The fruit is well distributed over the tree, and it bears well when carrying the crop from the previous year. This is unusual, for, in the case of most varieties of Oranges, if the crop is allowed to hang on the trees until late in the season, the following crop will be light. In habit of growth, the tree produces a well-rounded head, low and spreading, rather than higin and upright.

The remarkable feature about the Lue Gim Gong Orange is the way the fruit hangs on the trees. The fruit could be shipped in June, though still a little too acid. It is good in July, but better in August and September. The fruit is full of juice, and hangs on the trees through the rainy summer weather. It can therefore be placed on the market when Oranges are scarce and the highest prices obtainable can be secured. The fruit is of good market size, ships and keeps well.

\section{TESTIMONIALS}

The merits of the Lue Gim Gong Orange are recognized by all who have become acquainted with it. We might publish a large number of testimonials but the following from some of the men prominent in citrus fruit circles will suffice to show how it is regarded by those who know the fruit.

Mr. IT. C. Temple, Tampa, Fla., Secretary and Business Manager of the Florida Citrus Exchange, has done more to systematize the selling of Florida Citrus Fruits than any other man in the state. His ability as a grower and a packer of Oranges and grapefruit is too well known to need comment. Under date of June IT, I9I I, Mr. Temple wrote us as follows:

"Answering your favor of June I2, would say that I have several times in the last three years had occasion to in-



Telling the Story of the New Orange

vestigate, test and sample the Lue Gim Gong Orange, and would say that I consider it a marvel in the citrus family. I have eaten repeatedly- Oranges from the Lue Gim Gong tree that had been hanging matured for two years, and only today ate some that bloomed in February, I9Io, which put them through the cold snaps of December, January and February of the past season; and, although those Oranges are grown in a vicinity where much frost damage was done, they show no effect of frost whatever, being sound, solid and full of juice. I myself wish to get some of these Orange trees just the minute you are ready to put them on the market, as I wish to bud a considerable portion of my 'Alabama' grove into this variety, as in my' opinion the Lue Gim Gong Oranges will give to Florida what California alone now enjoys, viz., an all-the-year-round Orange."

An extract from a personal letter from Mr. MT. S. Hart, Hawks Park, Fla., sets forth his opinion of the Lue Gim Gong Orange. Mr. Hart has for years stood for all that is best in citrus fruit-growing in Florida, and no man is more competent to pass on the merits of a new variety. He says:

"During the.past two seasons, I have had some oportunity to study the peculiar merits of the Lue Gim Gong Orange, and I can honestly say that I have become convinced that it is the most promising money-producing proposition for the citrus grower now in sight." 
Mr. H. B. Stevens, General Manager of the John B. Stetson Estate, DeLand, Fla., one of Florida's most noted citrus-growers, has known the Lue Gim Gong Orange for a number of years past. In reply to our letter of inquiry, he writes as follows:

"You ask what I know of the Lue Gim Gong Orange. In reply, will say that I had my attention called to it several years ago, and have watched it quite closely ever since. Have come to this conclusion, that it stands more cold, both as a tree and as to the fruit, than any other Orange I have had any experience with. I have noticed that the fruit on the side budded to that variety stands more cold than the Harts Late budded on the opposite side of the same stump. It holds its juice late in the season, better than any other Orange I know of, and bears well. Can not see that the fruit remaining on the tree as late as it does seems to affect the amount of crop the next year. Taking it altogether, I think it promises to be one of the very best varieties we can have."

Col. G. B. Brackett, Pomologist, United States Department of Agriculture, Washington, D. C., has for years been identified with the fruit industries of the country, and has had an opportunity of examining more varieties of fruits than any other man in America. Colonel Brackett was chairman of the committee which awarded a Wilder Silver Medal from the American Pomological Society for the Lue Gim Gong Orange. He says:

"I have examined the specimens carefully, and upon their merits I have given my approval for the variety a Wilder Silver Medal, and have so informed (the Secretary) Prof. John Craig. I am having a painting made of the varicty for placing on file here. This is a rare good Orange, and I am glad you are taking an interest in it. . . This fruit is worthy, and I am glad to recognize its value by medal award."

Wilder Medal. The most noted horticultural organization in the country today, as it has been for the past sixty years, is the American Pomological Society. This Society, recognizing the merits of the Lue Gim Gong Orange, awarded a Wilder silver medal to this variety. We believe this is the first time a Wilder medal has been awarded for a new variety of Orange since the Socicty was organized, and gives a fair idea of the estimation in which this fruit is held by experts.
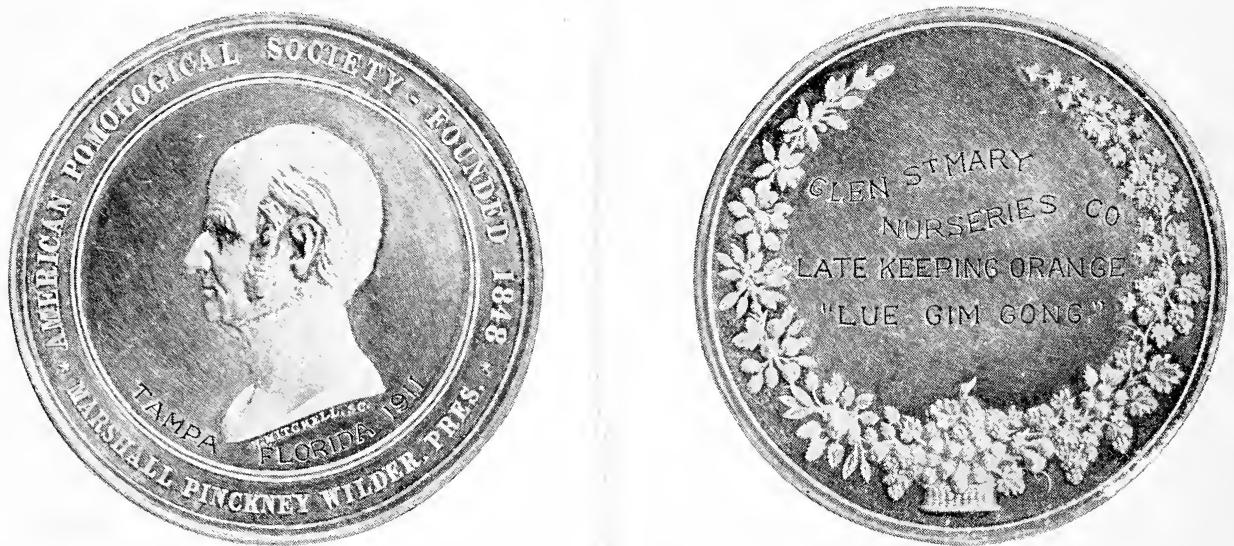

To every tree of this Orange sent out, a facsimile reproduction of the Wilder Medal, awarded by the American Pomological Society for the Lue Gim Gong Orange, will be fastened. This marks the tree as genuine stock-Glen Saint Mary grown.

PRICE.- The price of Lue Gim Gong Orange trees will be $\$ 3$ per tree, regardless of size or number of trees purchased. The trees will be graded in our regular sizes, 2 to 3 feet, 3 to 4 feet, and 5 to 7 feet grades. The earliest orders received will be filled with the largest sizes, and will be 4 to 5 fees, handled strictly in rotation. They will be pruned for planting before being sent out. Trees mostly on sour-orange stock. We can furnish a limited number on Citrus trifoliata stock.

While the price may be considered high by some, when compared with prices on other varieties, yet, when the real merits of the variety are considered, the price is low. Never, we venture to say, has a fruit tree of equal merit been presented to the public and sold at so low a figure. The first box of Oranges shipped out of the usual orange season in August or September will pay, or more than pay, for the tree which bore it.

\section{THE GLEN SAINT MARY NURSERIES CO. August 15, 1911 GLEN SAINT MARY, FLORIDA}


国

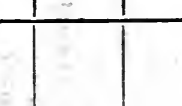



暗

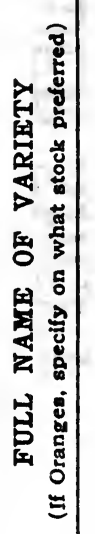

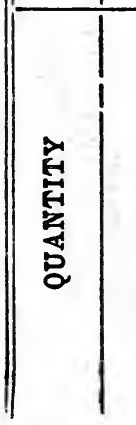









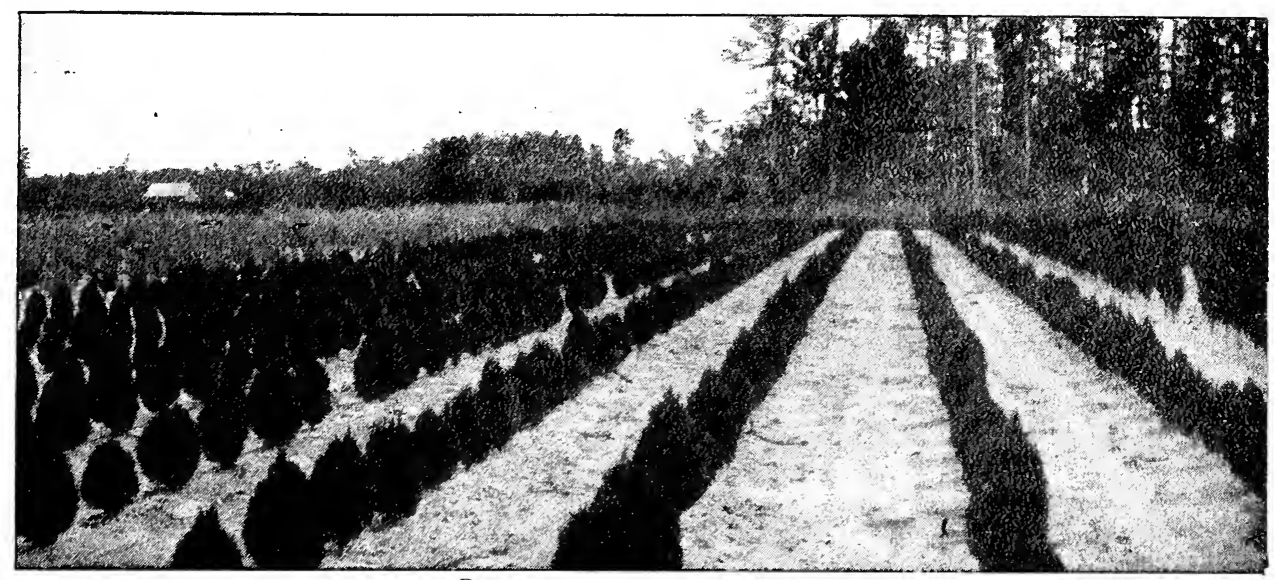

Biota aurea nana in Nursery rows

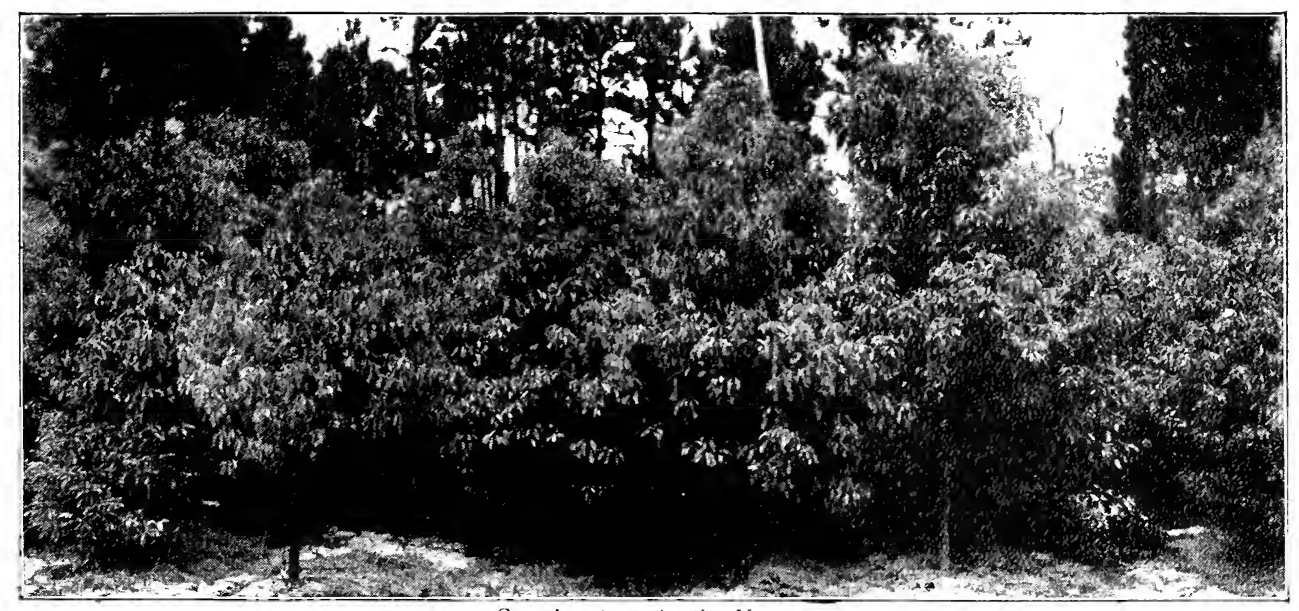

Camphor trees in the Nursery

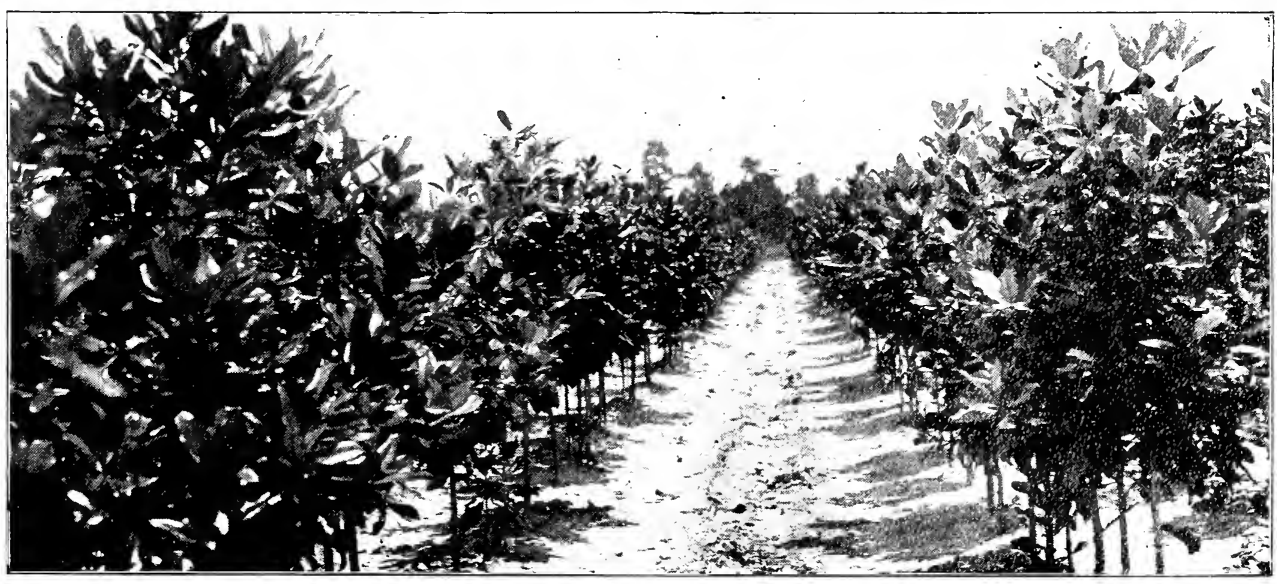

Magnolia grandiflora in the Nursery 


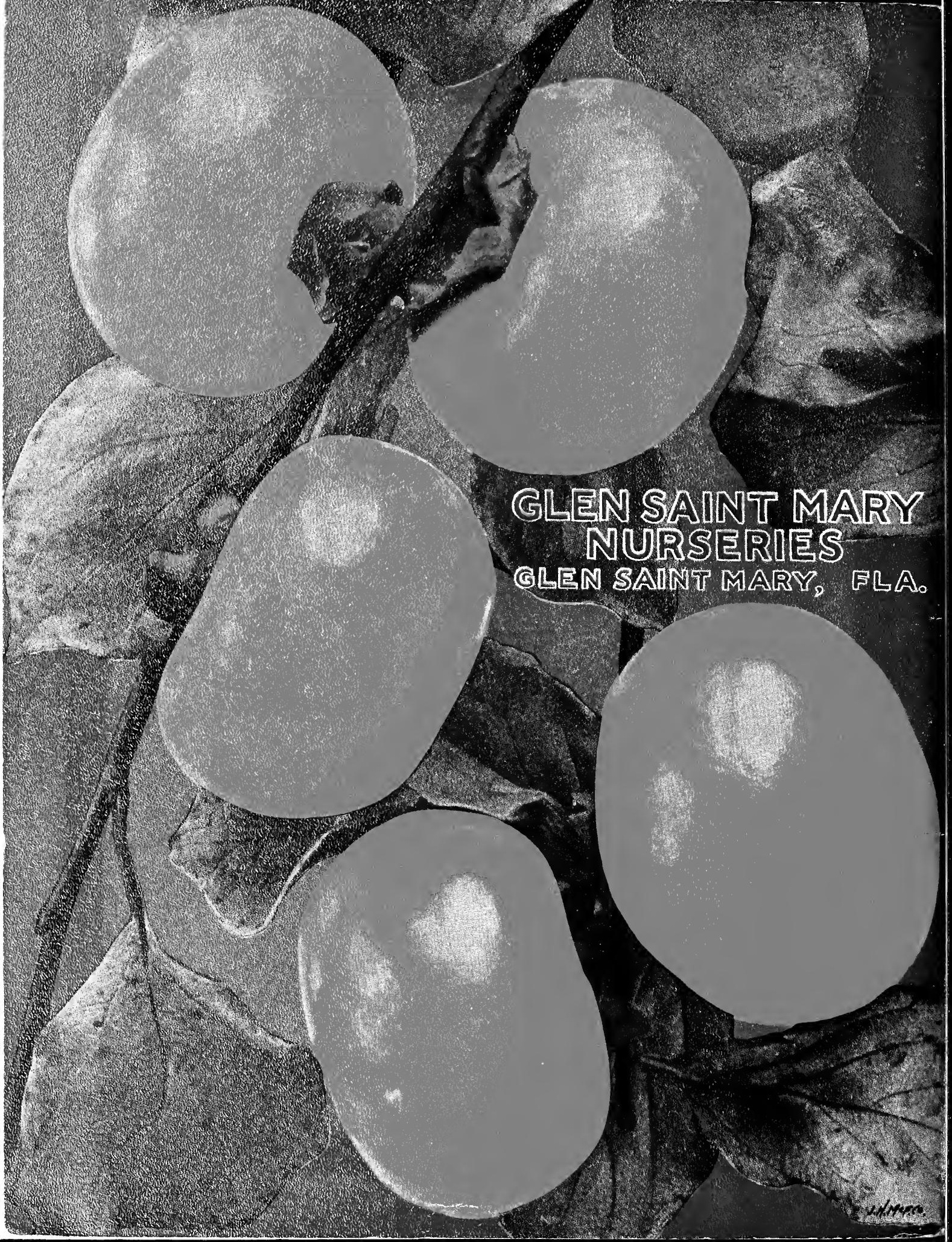

